NBER WORKING PAPER SERIES

\title{
BANKING ON THE BOOM, TRIPPED BY THE BUST: BANKS AND THE WORLD WAR I AGRICULTURAL PRICE SHOCK
}

\author{
Matthew S. Jaremski \\ David C. Wheelock \\ Working Paper 25159 \\ http://www.nber.org/papers/w25159 \\ NATIONAL BUREAU OF ECONOMIC RESEARCH \\ 1050 Massachusetts Avenue \\ Cambridge, MA 02138 \\ October 2018, Revised June 2019
}

The authors thank Lee Alston, Mark Carlson, Matteo Crosignani, Chris Hanes and participants in the 2018 Cliometrics conference, Central New York Economic History Conference, Economic History Association Annual Meetings, and NBER Summer Institute for comments on earlier versions of this paper. Views expressed herein are those of the authors and not necessarily official positions of the Federal Reserve Bank of St. Louis, the Federal Reserve System, or the National Bureau of Economic Research.

NBER working papers are circulated for discussion and comment purposes. They have not been peer-reviewed or been subject to the review by the NBER Board of Directors that accompanies official NBER publications.

(C) 2018 by Matthew S. Jaremski and David C. Wheelock. All rights reserved. Short sections of text, not to exceed two paragraphs, may be quoted without explicit permission provided that full credit, including $\odot$ notice, is given to the source. 
Banking on the Boom, Tripped by the Bust: Banks and the World War I Agricultural Price Shock

Matthew S. Jaremski and David C. Wheelock

NBER Working Paper No. 25159

October 2018, Revised June 2019

JEL No. E58,N21,N22

\title{
ABSTRACT
}

How do banks respond to asset booms? This paper examines i) how U.S. banks responded to the World War I farmland boom; ii) the impact of regulation; and iii) how bank closures exacerbated the post-war bust. The boom encouraged new bank formation and balance sheet expansion (especially by new banks). Deposit insurance amplified the impact of rising crop prices on bank portfolios, while higher minimum capital requirements dampened the effects. Banks that responded most aggressively to the asset boom had a higher probability of closing in the bust, and counties with more bank closures experienced larger declines in land prices.

\author{
Matthew S. Jaremski \\ Utah State University \\ Department of Economics and Finance \\ 3565 Old Main Hill \\ Logan, UT 84322 \\ and NBER \\ matthew.jaremski@usu.edu \\ David C. Wheelock \\ Research Division \\ Federal Reserve Bank of St. Louis \\ P.O. Box 442 \\ St. Louis, MO 63166-0442 \\ david.c.wheelock@stls.frb.org
}




\section{Introduction}

Asset price booms and busts are often intertwined with lending booms and busts. Although possibly triggered by a fundamental shock, rising asset prices can stimulate lending and increased leverage, which in turn causes asset prices to rise further, generating more lending, and so on. Similarly, falling asset prices can force debt contraction and deleveraging that reinforce the decline in asset prices. Large declines in asset prices can be disruptive, especially when preceded by rapid credit growth or involve highly-leveraged assets such as real estate (e.g., Kindleberger 1978; Minsky 1986; Borio and Lowe 2002; Eichengreen and Mitchener 2004; Reinhart and Rogoff 2009; Schularick and Taylor 2012). ${ }^{1}$ The interrelationship between asset prices and lending booms thus raises important questions, including how various regulations and policies might affect the vulnerability of the banking system to asset price shocks, and how bank lending and instability can exacerbate asset price movements.

Many studies have investigated these questions in the context of the U.S. house price boom of the early-to-mid 2000s and financial crisis of 2008-09. For example, researchers have highlighted the outsized role of the "shadow" banking system in supplying credit that fueled the boom (e.g., Loutskina and Strahan 2009; Mian and Sufi 2009), while others focused on credit demand (e.g., Glaeser et al. 2012; Dell'Ariccia et al. 2012). Still other studies have examined the impact of the financial crisis and bank distress on economic activity during and after the crisis (e.g., Campello et al. 2010; Ivashina and Scharfstein 2010; Chodorow-Reich 2014; Gertler and Gilchrist 2018). However, the complexity of modern financial systems, which include banks with international operations and off-balance sheet activities as well as shadow banks and other forms of intermediation, can obscure fundamental relationships. Thus, detailed examinations of episodes when such factors were not in play can be especially useful for identifying key relationships between asset booms and the banking system, as well as the effects of different policies that are hard to discern in more complex environments.

This paper studies the interplay of bank lending and asset prices in the boom-bust cycle affecting U.S. agricultural land prices during and after World War I. Unlike the recent U.S. house price boom, where the underlying shock or set of shocks that triggered the boom has proved difficult to identify conclusively, the farmland boom of the 1910s had a clearly

\footnotetext{
${ }^{1}$ Theoretical descriptions of how credit cycles can amplify real shocks include Rajan (1994), Kiyotaki and Moore (1997), Geanakoplos (2010), and Nuňo and Thomas (2017).
} 
identifiable trigger. ${ }^{2}$ The wartime collapse of European agriculture drove commodity prices sharply higher and constituted an external demand shock that sparked the boom in U.S. farmland prices. However, the boom was short-lived. European production bounced back quickly when the war ended, driving down crop prices and land values in the United States, and initiating a wave of farm foreclosures and bank failures in the early 1920s (Alston 1983; Alston, et al. 1994).

The historical episode is particularly advantageous for studying the interrelationships between lending and asset price booms and busts because bank lending at the time was decidedly local. Federal law prohibited interstate branch banking, and most states either prohibited or severely restricted branching within their borders. Moreover, with the automobile still in its infancy and paved roads almost nonexistent in rural areas, it would have been impractical for most farmers to obtain services from a bank located more than a few miles from their home. Thus, the balance sheet information we observe for individual banks reflects their lending to local farmers, and we can approximate local income shocks using detailed information about crop production in a bank's county. ${ }^{3}$ Specifically, we calculate a county-specific farm output price shock by applying the annual nation-wide price changes of 11 major crops to the county output shares of each crop before the war. This provides exogenous variation both across time and within a state to identify the effects of the price shock.

In two important studies of the episode, Rajan and Ramcharan (2015a, 2016) find that counties with more banks experienced larger increases in farmland prices and mortgage debt during the boom and suffered larger price declines and more bank failures during the bust. Whereas Rajan and Ramcharan examine the effects of credit availability (as reflected in the number of banks present in a county) and bank suspensions on county-level land prices, here we use biennial balance sheet data for individual banks in 18 agricultural states for 1908-20 to examine how the price shock affected i) the establishment of new banks, ii) bank portfolio decisions, and iii) the determinants of bank closures when farm prices and incomes ultimately collapsed. The bank-level data enable us to test whether state banking policies amplified or dampened the impact of asset price shocks on the banking system, and to use an instrumental

\footnotetext{
${ }^{2}$ Studies attribute the U.S. housing boom to, among other things, loose monetary policy (Taylor 2010), a savings "glut" and heightened demand for safe U.S. financial assets (Bernanke 2005), a bubble (Case and Shiller 2003), and financial market innovations including securitization of subprime mortgages (Loutskina and Strahan 2009; Mian and Sufi 2009).

${ }^{3}$ The county is a reasonable approximation of the area constituting a rural banking market at the time. Most empirical studies define banking markets at the MSA or rural county level even in modern times.
} 
variables approach to identify the impact of bank closures on county-level farmland values during the early 1920s. Our study thus provides insights about the channels by which the asset boom-bust affected the banking system and supply of credit, the role of government policies, and how banking instability contributed to the collapse of asset prices when commodity prices began to fall.

Our results show that rising crop prices encouraged entry of new banks and balance sheet expansion of new and previously established banks. While all banks expanded their assets and loans, those established during the war were especially aggressive lenders. New banks accounted for some one-third of the total increase in bank loans in our sample states between 1914 and 1920, and many increased their portfolio risk in response to rising crop prices. Similar to shadow banks in modern times, state-chartered banks responded more strongly to the boom than did more tightly regulated national banks. Moreover, we find that deposit insurance amplified the effects of rising crop prices on bank loan volumes, whereas higher minimum capital requirements deterred entry and dampened the effects of crop prices on loan growth and risk.

When farm prices and incomes collapsed in the early 1920s, banks that had expanded more during the boom had a higher probability of closing. Recently established banks were especially likely to close, as were banks with insured deposits, higher leverage, or larger shares of their portfolios devoted to loans. Further, banks located in counties with large increases in land values during the boom were more likely to close when prices fell. Finally, we find that bank closures exacerbated the collapse of farmland values during 1920-25. Thus, our research provides new evidence of how banks can both be affected by and contribute to asset price booms and busts, and how banking policies can influence the feedback loop around such events.

The paper proceeds as follows: Section 2 provides historical background about the agricultural boom-bust and the U.S. banking system at the time. Section 3 describes the data we use to estimate the interrelationship between banks and asset prices. Sections 4 and 5 examine the impact of the agricultural boom and bank regulation on the establishment of new banks and the balance sheets of new and previously established banks. Section 6 examines the determinants of bank closures during the bust. Section 7 estimates the contribution of bank closures to the collapse of farmland values in the 1920s. Section 8 concludes. 


\section{Historical Background}

In agricultural regions, fluctuations in farm output prices and incomes importantly influence the demand for funds and profit opportunities for local banks. The early 1900s were generally good years for farmers. Prosperity brought more land under cultivation and rising farm populations, as well as substantial growth in the number of commercial banks in farming communities. Because most states prohibited or severely restricted branch banking, market entry was almost solely in the form of new banks. ${ }^{4}$ Across the United States, the total number of banks more than doubled from 13,053 in 1900 to 27,864 in 1914; the South and Great Plains regions experienced increases of more than 200 percent (Board of Governors 1959, p. 33).

World War I transformed good years for farmers and their banks into boom years as the wartime demand for U.S. agricultural products caused prices to soar. Figure 1 shows that the unweighted average of 11 crop prices rose by 160 percent between 1914 and 1919, but also that the extent and timing of increases in the prices of individual crops varied. Whereas the prices of cotton, flaxseed, Irish potatoes, and tobacco rose by more than 200 percent, those of oats, rye, sweet potatoes, and buckwheat increased by less than 100 percent. $^{5}$

The wartime boom in farm output prices and incomes drove increases in land prices and mortgage debt, and drew still more banks to farming communities. Farmland value per acre rose by 51.4 percent on average between 1910 and 1920, with larger increases in the Midwest (60.6 percent), South ( 84.5 percent), and Great Plains (52.9 percent). ${ }^{6}$ As one might expect, land values increased most in agricultural regions where the principal crops had the largest price gains and where there was less available land to bring into production. Farmers often financed land and

\footnotetext{
${ }^{4}$ Banks with federal charters, i.e., national banks, were prohibited from opening branch offices, as were statechartered banks in most states, which hampered diversification and tied banks to the fortunes of their local communities. Calomiris (2000) argues that northern farmers opposed branching to ensure that local banks would continue to lend to them bad times as well as during prosperous periods, and in a 1924 referendum, voters in Illinois soundly rejected branch banking (White 1984). In the handful of states that allowed branching, few banks operated any branches outside their home office city. Among the agricultural states of the Great Plains, Midwest and South that comprise our sample, banks operated only 112 branches outside of their home office city in 1910 and 174 branches in 1920 (Board of Governors 1943, Table 74, pg. 299). Furthermore, most of those branches were of banks located in the largest cities of each state rather than banks located in farming communities. Thus, even where permitted by law, branching was extremely limited and largely irrelevant for the agricultural banks and regions that we study.

${ }^{5}$ By the early $20^{\text {th }}$ century, commodity markets were highly integrated within the United States and U.S. markets were well integrated with world commodity markets (see, e.g., Williamson 1996; Federico and Persson 2007; Sharp and Weisdorf 2013). The sharp increases, and subsequent decreases, in world prices associated with the external demand shock of World War I largely drove changes in U.S. crop prices and greatly overshadowed local variation in prices (United States Department of Agriculture 1922).

${ }^{6}$ Throughout this section, the regional data are unweighted averages of state-level observations.
} 
equipment purchases through banks and other lenders. ${ }^{7}$ Across all states, mortgage debt rose by an average of 83 percent between 1910 and 1920. Southern states experienced the largest increases (116 percent) while Northeastern states had the smallest increases (54 percent).

More than 3,000 banks were chartered across the United States during or shortly after the war, bringing the total to an all-time high of more than 31,000 banks, or about one bank for every 3,500 persons, in 1921. Relative to population, banks were especially prevalent in the Midwest and Great Plains, where states had as many as one bank for every 756 persons residing in the state. ${ }^{8}$ Many banks opened in towns that previously had no bank. For example, among states in the Midwest, Great Plains and South that make up our sample, 61 percent of new banks were established in towns that had no bank in 1910, and 30 percent were in towns that had only one bank. In total, bank loans rose by an average of nearly 100 percent across all states, though states in the Great Plains and South experienced somewhat larger increases (119 percent and 112 percent, respectively) than those in the Northeast (71 percent).

Most studies of the period conclude that farmers and their lenders expected crop prices to remain high after the war and thereby justify higher land prices. For example, Horton, Larsen and Wall (1942, p. 3) argue that "farm owners incurred debts and lenders made loans with the expectation that present or future increases in income and land values would support the debt." However, contrary to those expectations, European production recovered quickly when the war ended, and by 1921, crop prices were some 50 percent below their 1919 levels. The marked drop in commodity prices in 1920-21 and resulting decline in farm incomes caused farmland values to also collapse. Land values fell by an average of 27 percent between 1920 and 1925. Western states saw the largest average decline at 43 percent, but states in the South, Midwest, and Great Plains also experienced substantial declines of between 24 and 39 percent.

The post-war collapse of crop prices also brought a sharp increase in bank failures, voluntary liquidations, and mergers, producing the first sustained decline in the number of U.S.

\footnotetext{
${ }^{7}$ Loans during the period typically were a short-term with balloon payment rather than long-term with selfamortizing payments. The average term of farm mortgage loans recorded by banks during 1917-21 was 2.7 years, ranging from 1.4 years in the South to nearly 5 years in New England (Horton, Larsen, and Wall 1942, Table 74). During the postbellum period, non-bank sources of farm loans included insurance companies, building and loan associations, federal land banks, and other local farmers and merchants (Jaremski and Fishback 2018). In 1920, commercial banks held 14 percent of outstanding farm mortgage debt, life insurance companies held 11 percent, federal land banks 3 percent and private individuals 70 percent (Horton, Larsen and Wall 1942).

${ }^{8}$ North Dakota had one bank for every 756 persons. Other states with similar numbers included Iowa $(1,257)$, Nebraska (1,073), and South Dakota (914). The ratio is calculated by dividing the number of banks in 1921 (Board of Governors 1959) by state population in 1920.
} 
banks since the Civil War. After peaking in 1921, the number of banks fell by some 5,000, or 16 percent, over the 1920s. Bank suspension rates were especially high in states of the Pacific, Great Plains, and South regions where many new banks had opened during the prior decade. ${ }^{9}$

Suspension rates were also generally higher among state-chartered banks (state banks) than among banks with federal charters (national banks). Differences in the composition and regulation of banks likely contributed to these differences. National banks were subject to uniform and relatively strict standards across all states, whereas state banks were subject to the laws, regulations, and policies established by the state in which they were located. In particular, state banking regulations were more liberal toward mortgage loans for farmland, building, and equipment purchases. ${ }^{10}$ Both federal and state banking laws prohibited interstate branching. National banks were prohibited from operating any branches, and most states either prohibited or severely limited intrastate branching. Thus, entry nearly always took the form of a new bank, rather than a new branch of an established bank. State legislatures often set low minimum capital requirements to encourage state-chartered banks to open in rural communities, however, whereas national banks faced higher minimums, which held down their numbers in small towns. Thus, while both bank types were present in large numbers in farming communities, national banks were more prevalent in larger cities and less heavily involved in farm lending than state banks.

State banking policies likely also affected banks' ability and incentives to engage in highrisk lending. Deposit insurance, which eight states adopted during the 1910s and early 1920s, was one such policy. Intended to protect depositors from losses, all of the systems collapsed in the 1920s with most failing to cover fully the deposits in failed banks (FDIC 1956). Insurance assessments were a flat rate based on a bank's total insured deposits rather than risk based. Contemporaries argued that the insurance systems promoted excessive risk taking and growth of state banking systems (Flood 1992), which recent studies have largely borne out. For example, Calomiris and Jaremski (2019) find that insured banks generally had faster loan growth rates

\footnotetext{
${ }^{9}$ Suspensions include banks that failed or otherwise suspended operations because of financial difficulties. Some banks that suspended later reopened, though most did not.

${ }^{10}$ Before 1914, national banks were generally prohibited from real estate lending. However, the Federal Reserve Act (38 Stat. 251, 273), Section 24, specified "Any national banking association not situated in a central reserve city may make loans secured by improved and unencumbered farm land ... but no such loan shall be made for a longer time than five years, nor for an amount exceeding fifty per centum of the actual value of the property offered as security. Any such bank may make such loans in an aggregate sum equal to twenty-five per centum of its capital and surplus or to one third of its time deposits...." A 1916 amendment clarified that farm mortgages made by national banks against property other than farmland could have a term of no more than one year.
} 
than uninsured banks. Moreover, they find evidence that depositors monitored bank risk taking in that deposit flows were responsive to changes in bank loan portfolios and leverage when deposits were not insured, but not after deposit insurance was implemented. Deposit insurance also seems to have exacerbated the impact of the post-war collapse of farm prices and incomes on bank loan growth, risk-taking and suspension rates (e.g., Calomiris 1992, Alston, et al. 1994, Wheelock and Kumbhakar 1995, Wheelock and Wilson 1995, and Dehejia and Lleras-Muney 2007). ${ }^{11}$

Minimum capital requirements, extended liability laws, and Federal Reserve membership were among other banking policies that might have affected how banks in different locales responded to changes in asset prices. Capital requirements, in the form of either higher minimum capital amounts required to obtain a bank charter or extended liability on bank shareholders were entry barriers that might have discouraged risk taking and the formation of new banks. ${ }^{12}$ The effects of Federal Reserve membership are less obvious. Member banks were generally subject to tougher regulations and supervision than non-member state banks, which might have deterred risk taking, but the availability of the Fed's discount window provided a liquidity backstop that might have encouraged risk taking. Regardless, few state banks became Fed members, likely because they perceived that the costs of membership outweighed the benefits. ${ }^{13}$

The remainder of this paper attempts to fill out the story of the World War I agricultural price shock by examining how banks responded to the boom, how banks fared during the bust, and how the presence and lending of banks influenced the course of farmland values. Because state and national banks faced very different regulatory regimes, in our empirical analysis, we examine the response of national banks to the agricultural price shock and local banking regulations separately from that of state banks.

\footnotetext{
${ }^{11}$ The evidence that deposit insurance promoted banking instability in the 1920s is consistent with studies that examine other periods, including Keeley (1990), Demirgüç-Kunt and Detragiache (2002), Demirgüç-Kunt and Huizinga (2004), Barth et al. (2006), and many others.

${ }^{12}$ Carlson et al. (2018) find that national banks in markets with low minimum capital requirements supplied more credit, chose higher leverage, and were more likely to fail during or soon after the Panic of 1893, than were banks in markets with higher minimum capital requirements.

${ }^{13}$ Federal Reserve membership was compulsory for national banks. However, even as late as 1929 , fewer than 10 percent of state banks had joined the Federal Reserve System. Anderson et al. (2018) find that larger state banks and those which provided services for other banks were more likely to join. Carlson and Wheelock (2018) find that national banks were less liquid after the Fed's establishment than before, suggesting that banks responded to the Fed's founding by shifting toward less liquid loans and securities.
} 


\section{Data}

To examine the effects of the World War I agricultural boom and subsequent bust on the banking system, we merge county-level census data with bank-level balance sheet data. Our sample includes only states in the South, Midwest, and Great Plains that published bank-level information so as to focus on a balanced sample of locations where farming was a large share of economic activity. And, to focus further on farming areas within those regions (rather than urban and manufacturing centers) we include only counties that had (1) no city with a population over $25,000,(2)$ at least 250 farms, and (3) over 15,000 improved farm acres. ${ }^{14}$

The county-level census dataset contains economic and demographic information for $1900,1910,1920$, and $1925 .{ }^{15}$ Of particular interest is the county-level output of each farm crop. Combining output data for 1910 with annual information on prices for 11 individual crops (corn, wheat, oats, barley, rye, buckwheat, flaxseed, cotton, tobacco, Irish potatoes, and sweet potatoes) from Carter et al. (2006), we form a county-specific crop price index for each year:

$$
\text { CropIndex }_{c, t}=\frac{\sum_{i=1}^{11} Q_{i, c, 1910} * P_{i, t}}{\sum_{i=1}^{11} Q_{i, c, 1910} * P_{i, a v g}}
$$

where $Q_{i, 1910}$ is the output of crop $i$ in county $c$ in 1910, $P_{i, t}$ is the price of crop $i$ in year $t$, and $P_{i, a v g}$ is the average price of crop $i$ between 1908 and 1914. The index is the value of a basket of crops at market prices in a given year normalized by the value of that same basket of crops at their pre-war prices, where the county-specific crop output shares in 1910 determine the fixed basket. The normalization is important to control for differences in the geographic size of counties, as well as in the relative size of each county's agricultural sector before the boom. The measure takes an average value of 1 before World War I and rises throughout the war years.

As the county-level basket of crops is held constant in 1910 and the crop prices are national averages, CropIndex cr,t $_{\text {has }}$ the benefit of being exogenous to the actions of local banks. Of course, output levels and crop mix likely changed in response to rising farm incomes and

\footnotetext{
${ }^{14}$ We chose the cutoff points for farms and improved acres to eliminate the bottom 5 percent of the distribution. We chose the population cutoff because the Census provides the number of people living in places with more than 25,000 for every county.

${ }^{15}$ The data were assembled by Haines (2004). We aggregate counties to their 1910 boundaries so as to have consistent county definitions over time.
} 
changes in relative prices. ${ }^{16}$ Our approach misses these shifts, but avoids any reverse causality that local lending or changes in land values might have had on the measured crop price shock.

Figure 2 illustrates the county-level geographic variation in the crop price index and the percentage change in farmland value during the war. The top panel shows that the South, where cotton and tobacco were dominant crops, and the upper Midwest, where buckwheat and Irish potatoes were widely grown, generally experienced larger price gains than the Midwest and Great Plains, where corn and wheat were major crops. The bottom panel shows that the change in land value per acre followed a similar pattern: the largest gains in land values were in the cotton growing portions of the South, and the smallest gains were in the corn growing regions of the Midwest. The correlation is not perfect, however. For example, northwestern Iowa and southeastern South Dakota experienced large gains in farmland values despite relatively modest increases in the prices of the region's principal crops (corn and wheat). The two maps also illustrate the substantial within-state variation in average crop price and land value increases, which we rely on to identify differential effects of the price shock on banks and farmland values.

Our bank data consist of biennial, bank-level balance sheet information for 1908-20, obtained from Annual Report of the Comptroller of the Currency and reports published by state banking departments. The Comptroller published balance sheets for every national bank annually, but many states did not publish balance sheets for their state-chartered banks before 1908, and most only published information every other year (see Mitchener and Jaremski 2015). We digitized data from the available state reports for Alabama, Florida, Georgia, Illinois, Iowa, Kansas, Louisiana, Michigan, Minnesota, Mississippi, Missouri, Nebraska, North Carolina, Ohio, Oklahoma, South Dakota, and Wisconsin, and interpolated values for the few reporting gaps using the midpoint of data for the immediately surrounding years. The resulting biennial dataset consists of 72,547 observations on 11,914 state banks and 2,989 national banks. ${ }^{17}$

\footnotetext{
${ }^{16}$ The crop index using the 1920 basket of crops has a 0.92 correlation with that for the 1910 basket, suggesting there was not a substantial change in the distribution of crop production during the war. The lack of a change should not be surprising as soil, climate, and market infrastructure largely determined the cash crops that could be grown profitably in a given location.

${ }^{17}$ We interpolate less than 6 percent of observations. The results are similar if we instead drop these observations. Throughout the paper, the term "state banks" refers to state-chartered commercial banks, trust companies, and savings banks. All of these financial intermediaries took deposits and made loans. At the time, banking reports did not include income statements or information about the interest rates paid on deposits or loans, thereby making it impossible to calculate profit rates. We add 1 to the number of banks in each county to avoid missing values for the few counties that did not have any banks. Appendix Table A.1 reports summary statistics for both the county and bank-level data.
} 


\section{Responding to the Price Shock: Establishment of New Banks}

One impact the price shock might have had on the banking system was to spur bank entry. Federal and state prohibitions on branching meant that the establishment of new banks, rather than new branches of existing banks, was the dominant form of entry. Researchers have documented that de novo banks generally have much higher failure rates than established banks (e.g., DeYoung 2003). Thus, the agricultural boom might have contributed to banking system instability by encouraging the establishment of new banks, many of which ultimately closed. ${ }^{18}$

We estimate negative binomial count data regressions to investigate the impact of the agricultural price shock and various bank regulations on bank entry at the county-level. The dependent variable is the number of new banks established during a two-year period. The main explanatory variable is the crop price index measured at the end of the prior period. ${ }^{19} \mathrm{We}$ estimate the following specification using biennial data from 1908 to 1920 (where entry during 1908-09 is the first observation):

$$
\begin{aligned}
\text { NewBanks }_{c, t} & =a+\beta_{1} \text { CropIndex }_{c, t-1}+\beta_{2} \text { Regulation }_{c, t}+\beta_{3} \text { Regulation }_{c, t} \\
& * \text { CropIndex }_{c, t-1}+\beta_{4} X_{c, t}+t_{t}+c_{c}+e_{c, t}
\end{aligned}
$$

where NewBanks$s_{c, t}$ is the number of new banks entering county $c$ during the biennial period $t$, CropIndex $_{c, t-1}$ is the crop price index in county $c$ at the end of the previous biennial period, Regulation $_{c, t}$ is a vector of bank regulations in county $c$ in biennial period $t$ including a dummy variable for whether the state had an active deposit insurance system, a dummy variable for whether the state imposed extended liability on state bank shareholders, ${ }^{20}$ and a dummy variable for whether the state set a minimum capital requirement of more than $\$ 10,000$ on state banks. $X_{c, t}$ is a vector of county-specific census control variables for county $c$ in the biennial period $t$, $t_{t}$ is a vector of year fixed effects, $c_{c}$ is a vector of county fixed effects, and $e_{c, t}$ is a robust error

\footnotetext{
${ }^{18}$ The early 2000s housing boom was not associated with growth in the number of commercial banks. However, the boom did increase both the demand for and supply of credit, and was associated with growth of the shadow banking system and easing of lending standards (e.g., Loutskina and Strahan 2009; Mian and Sufi 2009; Dell'Ariccia et al. 2012; Gorton and Metrick 2012).

${ }^{19}$ In the Appendix, we show that the effects of the crop price index are similar if we use the lagged change in the crop price index (Table A.2) a cross-section from 1914 to 1920 (Table A.3), or either a tobit regression of the entry rate (Table A.5) or a probit model of entry or no entry in a given year (Table A.6). Finally, Table A.4 combines both state and national bank data into one model to show that the effect of the crop price index is larger for state bank entry than for national bank entry.

${ }^{20}$ Shareholders of national banks could be assessed an amount equal to the par value of the stock they held in the event the bank failed, which is commonly referred to as double liability. Some states also imposed double liability on bank shareholders. A few states imposed other multiples at times, but according to Grossman (2001), the "vast majority" of states with any form of extended liability imposed double liability.
} 
term clustered by county. As the county fixed effects control for location characteristics that are constant over time, Equation (1) includes only those census control variables that vary over time: the logarithms of county population and manufacturing output per person, the fraction of county population living in a city or town of 2,500 or more persons, the fractions of county population that are non-white, illiterate, or 15 years of age or younger, and the numbers of state and national banks in the county at the beginning of the period. ${ }^{21}$ Note that because we include year fixed effects, the effect of the increase in a county's crop price index is only identified relative to the sample average increase of the crop price index.

Studies of bank entry in other settings find that local economic opportunities, market size, and legal barriers all affect entry (e.g., Adams and Amel 2016; Adams and Gramlich 2016). The crop price index observed at the beginning of a two-year period captures the economic opportunities that encouraged entry. Both the level of each policy variable and its interaction with the crop price index reflect the effects of regulation and other banking policies. The presence of county-fixed effects in the model implies that the coefficients on the levels only capture the effects of any changes in the policy. While these effects are important, there were few changes during our period of study and the asset boom does not seem to have caused them. ${ }^{22}$ Hence, we treat the levels of the regulatory variables as controls that vary over time for the type of institutions and political environment the bank was operating in at that point in time, and we focus on the interactions, which indicate how the particular policy affected the impact of the crop price shock on bank entry rates.

\footnotetext{
${ }^{21}$ We assume that the census variables grew linearly over time to construct annual estimates from the decennial observations.

${ }^{22}$ Among our sample states, deposit insurance systems were established in Kansas, Mississippi, Nebraska, Oklahoma, and South Dakota. State banks were required to join the deposit insurance systems in all of these states except Kansas, where membership was voluntary. National banks were not permitted to join state deposit insurance systems. While all national bank shareholders were subject to double liability, several of our sample states also imposed extended liability on state banks, including Florida, Georgia, Illinois, Iowa, Kansas, Michigan, Nebraska, North Carolina, Oklahoma, South Dakota, and Wisconsin, but only Mississippi and Ohio adopted extended liability during our sample period. Finally, nine states set minimum capital requirements for their state banks at $\$ 10,000$ (or $\$ 5000$ in the case of North Carolina), while three had minimums above $\$ 10,000$ ( $\$ 15,000$ in Alabama, Florida and $\$ 25,000$ in Ohio). Six states changed their minimums between 1910 and 1920 , but only four crossed the $\$ 10,000$ threshold: Illinois decreased from $\$ 25,000$ to $\$ 10,000$; Michigan decreased from $\$ 20,000$ to $\$ 10,000$; Nebraska increased from $\$ 10,000$ to $\$ 15,000$; South Dakota increased from $\$ 10,000$ to $\$ 15,000$. The identities of states that imposed double liability are from Grossman (2001). Information on minimum capital requirements is from White (1983) and Rand McNally Bankers' Directory. See Benmelech and Moskowitz (2010), Mitchener and Jaremski (2015), Rajan and Ramcharan (2015b), Calomiris and Jaremski (2016) for studies on the political economy of various bank regulation during the period.
} 
As discussed in Section 2, national banks faced substantially different regulations than state banks and were particularly restricted from engaging in mortgage lending. Thus, we expect that national banks responded differently to rising crop prices than did state banks (a hypothesis that we explicitly test in the Appendix tables), and hence estimate Equation (1) separately for state and national banks. ${ }^{23}$

The estimation results for Equation 1, shown in Table 1, indicate that crop prices had a positive and statistically significant impact on the entry of state banks, but not of national banks. Because they generally faced higher minimum capital requirements and tighter restrictions on mortgage lending than state banks, national banks were more likely to open in larger cities, and less likely to lend directly to farmers in rural areas.

We also find some evidence that banking policies affected how the shock affected bank entry. Specifically, we estimate that in states with a minimum capital requirement above $\$ 10,000$ (the median among our sample states), the effect of a given change in the crop price index on entry of state banks was approximately one-half of the effect on entry in states with a lower minimum capital requirement. Further, the negative correlation between national bank entry and the crop price shock was predominately in states that had relatively high minimum capital requirements on state banks, suggesting further that national banks were imperfect substitutes for state banks. Finally, the results indicate that neither deposit insurance nor extended liability statutes affected consistently the impact of crop prices on the establishment of either bank type. ${ }^{24}$

\section{Responding to the Price Shock: Loan Growth and Balance Sheet Risk}

In addition to encouraging the formation of new banks, rising farm prices and incomes likely affected bank growth rates and portfolio allocations. Using bank-level balance sheet data, we examine how the agricultural price shock affected the growth of total assets and loans, as well as ratios of loans to assets (loans/assets), paid-in capital, surplus, and undivided profits to assets (capital/assets), liquid reserves to assets (cash/assets), and bonds and stocks to assets (bonds/assets) of banks. Many studies across many settings find that bank failure risk is

\footnotetext{
${ }^{23}$ To test that the responses of national banks were fundamentally different than those of state banks, we estimated each of the models reported in the paper on pooled data for state and national banks and included separate interaction terms for state banks. F-tests reject the hypothesis that the coefficients on the state bank interaction terms are jointly equal to zero in every case. See Appendix Tables A.4, A.11, and A.12.

${ }^{24}$ Calomiris and Jaremski (2019) also find that deposit insurance did not significantly affect the number of banks at the state-level, but did not examine bank entry rates explicitly or examine the number of banks at the county-level.
} 
correlated with these measures. Thus, the analysis provides evidence about whether banks' response to the boom contributed to banking system instability by increasing failure risk.

The model, which we estimate using biennial bank-level observations from 1908 to 1920 , is as follows:

$$
\begin{gathered}
Y_{i, c, t}=a+\beta_{1} \text { CropIndex }_{c, t}+\beta_{2} \text { Regulation }_{c, t}+\beta_{3} \text { Regulation }_{c, t} * \text { CropIndex }_{c, t}+\beta_{4} X_{c, t} \\
+\beta_{5} \text { CropIndex }_{c, t} * Y r 1918+t_{t}+u_{i}+e_{i, c, t}(2)
\end{gathered}
$$

where $Y_{i, c, t}$ is one of the specified balance sheet variables for bank $i$ in county $c$ during biennial period $t, \operatorname{Yr} 1918$ is a dummy variable that takes the value 1 in 1918 and 0 otherwise, $u_{i}$ is a vector of bank-fixed effects, $e_{i, c, t}$ is the error term clustered by county, $X_{c, t}$ now contains all the previous variables with the addition of the numbers of state and national banks in the current year, Regulation ${ }_{c, t}$ now contains a dummy variable for Federal Reserve membership during biennial period $t$ and the deposit insurance indicator variable for the state bank regression is at the bank-level rather than the state-level, and the rest of the variables retain their previous definitions. In these regressions, we include the interaction between the crop price index and the 1918 dummy to control for any differential effects of the price shock on banks when the United States was at war. During the war, the U.S. government and Federal Reserve encouraged banks to purchase government bonds and to provide funds to help their customers buy bonds (Meltzer 2003, pp. 84-90). This pressure might have altered how banks responded to rising crop prices in those years.

We again estimate Equation (2) separately for state banks (Table 2) and national banks (Table 3) to account for the differing regulation. ${ }^{25}$ Focusing first on state banks, the specification in the first column of each set reveals a positive and statistically significant impact of the crop price index on total assets and loans. We estimate that a doubling of the crop price index increased a state bank's assets by 23.0 percent and loans by 23.7 percent. Further, the coefficients on the crop price index are positive for loans/assets and cash/assets, and negative for capital/assets and bonds/assets. Specifically, we estimate that a doubling of the crop price index increased loans/assets by an insignificant 0.4 percentage points and cash/assets by 1.3 percentage

\footnotetext{
${ }^{25}$ In the Appendix, we report estimates of the balance sheet regressions in several different ways to show that the results are robust to the modeling choices. Table A.7 reports a cross-sectional regression for 1914-20 to show a total effect. Tables A.8 and A.9 report the results when including an autoregressive term to account for any serial correlation in the balance sheet items. Table A.10 adds the lagged value of total assets to the balance sheet ratios models to control for bank size. Table A.11 combines state and national banks into a single model to show that the effect on state banks was much larger than that on national banks.
} 
points, while reducing both capital/assets and bonds/assets by 3.0 percentage points. The effects are quantitatively modest, though statistically significant (except for loans/assets), and somewhat ambiguous about whether banks in general responded to the boom by increasing their overall risk.

Next we test whether banks established during the war responded differently to the boom than did older banks. Berger and Udell (2004) find that in general, the quality of a bank's loans is lower when a higher proportion of the bank's loan officers have never experienced severe loan losses, or when the time since the bank last experienced a bust is long, which they argue contributes to the tendency for loan growth to be procyclical. Thus, conceivably, banks that opened during the boom were more aggressive lenders than older banks because older banks were more likely to have encountered economic distress in the past, or had higher charter values to protect. To test this hypothesis, we include an interaction of the crop price index with a dummy set equal to 1 for banks that were established between 1914 and 1920 in the second and third regressions in each set.

For state banks, the coefficients on the young bank interaction term indicate that for a given increase in the crop price index, the total loans and loans/assets of newer banks increased much more than those of older banks. Specifically, we estimate that the loan volumes of newer banks increased approximately 17 percent more for a given increase in the crop price index than did the loans of established banks. Moreover, whereas the impact of the crop price index on loans/assets of older banks was small and not statistically significant, the impact on the ratio for new banks is positive and significant. A doubling of the crop price index increased loans/assets by 2.5 percentage points for young banks, compared with an increase of 0.1 percentage points for older state banks. Similarly, the impact of the crop price shock on capital/assets was nearly 50 percent larger for young banks than it was for older banks. We estimate that a doubling of the crop price index caused capital/assets of young banks to decline by 4.1 percentage points, compared with a decline of 2.8 percentage points for older banks. Finally, the regressions indicate that whereas an increase in the crop price index increased the cash/assets ratio for older banks, it had no effect on the ratio for young banks. Thus, the evidence indicates that newer state banks responded more aggressively to the agricultural price shock than did older state banks.

The third column of each set of regressions includes the interactions between the banking policy variables and the crop price index to test whether specific regulation altered banks' 
response to the shock. The negative coefficients on the interaction of the minimum capital requirement dummy variable with the crop price index indicate that the impact of a given crop price index value on total loans, total assets, and loans/assets was smaller in states with relatively high minimum capital requirements. To the extent that higher minimums gave rural banks a degree of local monopoly power, they likely encouraged conservative behavior and hence less asset and loan expansion as well as higher reserves and lower leverage in response to a local price shock. The positive coefficients on the interaction of extended liability with the crop price index indicate that extended liability boosted the impact of crop prices on assets, loans, and loans/assets, suggesting that it did not deter banks from responding aggressively to rising crop prices. Grossman (2001) finds that extended liability generally reduced risk taking except in periods of heightened financial distress, including the early 1920s, and notes that extended liability was widely viewed as ineffective at containing banking system risk and eventually eliminated in the $1930 \mathrm{~s}$.

Finally, deposit insurance seems to have amplified the impact of crop prices on total loans, assets, and capital/assets ratios of banks in state deposit insurance systems. The results support previous studies that find that members of the state deposit insurance systems grew faster and assumed more risk than did uninsured banks.

The results reported in Table 3 indicate that national banks were less responsive to rising crop prices, particularly in terms of the extensive growth measures. The baseline regressions, which exclude policy interactions, reveal no evidence that national banks systematically increased their total loans or loans/assets in response to crop prices. In line with national bank entry, we find a negative correlation between total assets in national banks and the crop price index, indicative of a redistribution of bank assets away from national banks to state banks in response to rising crop prices. Further, we find no differences in the balance sheet ratio responses of newer national banks and those established before the boom.

The national bank results suggest some policy effects, however. Rising crop prices had a larger impact on national bank assets, cash/assets, and bonds/assets after banks became Fed members, but less impact on total loans and loans/assets. However, because all national banks became Fed members when the System was established in 1914, the interaction cannot clearly separate the effect of becoming a member from the effect of the beginning of World War I. The results also indicate that national banks located in states with higher minimum capital 
requirements for state banks experienced a reduced impact of crop prices on loans, assets and loans/assets for national banks, similar to state banks. Thus, minimum capital requirements appear to have been an especially effective brake on bank expansion in response to fundamental shocks. By contrast, the effects on national banks of extended liability and deposit insurance regimes for state banks are more mixed. However, as with state banks, deposit insurance tended to amplify the impact of crop prices on total loans and assets, suggesting that even though national banks were not eligible for insurance, they responded in a manner consistent with their insured state bank competitors.

Our results reveal several dynamics about the boom. First, the agricultural price shock produced large increases in the assets and loans of state banks that were established before 1914, and even larger increases for banks that opened during the boom. Newly-established banks accounted for one-third of total loan growth between 1914 and 1920 in our sample counties. Moreover, the contribution of younger banks to total growth was larger in states with deposit insurance and smaller in states with high minimum capital requirements. Furthermore, while the results are somewhat ambiguous as to whether older banks responded to rising crop prices by taking on greater balance sheet risk, state banks established during the boom seem to have responded more aggressively to rising agricultural prices by increasing their loans/assets and leverage (i.e., by reducing capital/assets).

Second, crop prices had much less impact on the loan growth of national banks, likely because of their more limited role in financing agricultural investment and production. Moreover, unlike the more aggressive response of newer state banks than older banks, we find no evidence of differences in the responses of national banks based on when they were established. The fact that state banks responded much more strongly than national banks to agricultural fundamentals indicates that our crop price index reflects the agricultural price shock rather than other factors correlated with World War I.

Third, bank regulations and policies affected the response of state banks to the price shock (and even the response of national banks to some extent). High minimum capital requirements lessened the impact of rising farm output prices on the growth of bank assets and loans, and balance sheet ratios correlated with risk, whereas deposit insurance amplified those effects. Extended liability statutes, however, were apparently not a deterrent to an aggressive response to rising crop prices. 


\section{Which Banks Closed During the Bust?}

Farm output prices collapsed in 1920 and farmland values quickly followed. With much lower incomes, many farmers were unable to repay mortgages and other loans incurred during the boom, resulting in the failures of hundreds of banks in farming regions. Across the United States, 1,787 commercial banks suspended operations during 1921-24, representing about 6 percent of active banks in 1921. Suspensions were highly concentrated in farm states; Minnesota, Iowa, Missouri, North Dakota, South Dakota, Nebraska and Kansas combined for 947 suspensions (Board of Governors 1943, p. 284). Our bank-level data enable us to test various hypotheses about the causes of individual bank closures during the bust. ${ }^{26}$

We estimate a probit model to examine the determinants of bank closures between 1920 and 1924. Our specification is similar to those estimated in other settings, such as the Great Depression (White 1984), 1980s-90s (Wheelock and Wilson 1995, 2000), and Great Recession (Cole and White 2012), in which the closure outcome is regressed on bank age as well as various balance sheet measures intended to capture bank performance and risk. Larger banks might have more opportunities for diversification or scale economies, and thus we anticipate that banks with more total assets are less likely to close. We anticipate that higher loans/assets would increase the likelihood of closure because loans are typically a bank's most risky assets. By contrast, we expect that greater liquidity (reflected in higher cash/assets) or capital (reflected in higher capital/assets) would reduce the probability of closure. Finally, older banks might be better managed or have more stable funding, and thus we expect that the closure probability was lower for older banks, even leaving aside their less aggressive response to the boom noted previously.

We also test whether the asset boom affected closure rates directly, rather than simply through their observable impact on bank balance sheets. We include the percent changes in farmland value per acre, mortgage debt per acre, and improved farm acreage between 1910 and 1920, as well as the log of mortgage debt per acre in 1920 to capture the boom. ${ }^{27}$ We do not include measures of the bust, such as the change in farmland value during 1920-25, because they might be determined in part by local bank closures. The model takes the form:

\footnotetext{
${ }^{26}$ A bank might close because it failed, voluntarily liquidated, merged with another bank, or changed its name or charter type (e.g., a state bank that switched to a national charter), and neither state reports nor Rand McNally provide consistent information about why individual banks closed. Because mergers, acquisitions, and name changes were often undertaken for reasons correlated with bank distress, this should not bias the results in any particular direction.

${ }^{27}$ Throughout the paper, our measures are in nominal dollars because mortgages and other loans were not indexed for inflation, and bank failures reflected the performance of bank assets in nominal, rather than real terms.
} 


$$
\begin{aligned}
\text { Closure }_{i, c}= & a+\beta_{1} \text { LLandValue }_{c, 1910-20}+\beta_{2} \Delta \text { ImpAcres }_{c, 1910-20}+\beta_{3} \Delta \text { MtgDebt }_{c, 1910-20} \\
& +\beta_{4} \text { MtgDebt }_{c, 1920}+\beta_{5} \text { Regulation }_{c, t} * \Delta \text { LandValue }_{c, 1910-20}+\beta_{6} X_{c, 1920} \\
& +\beta_{7} B_{i, 1920}+s_{s}+e_{i, c}(3)
\end{aligned}
$$

where Closure $_{i, c}$ is a dummy variable set to 1 if bank $i$ in county $c$ closed before 1924, $\Delta$ LandValue $_{i, 1910-20}$ is the percent change in farmland value per acre in county $c$ between 1910 and 1920, $\Delta$ ImpAcres $_{c, 1910-20}$ is the percentage growth in improved acres in county $c$ between 1910 and 1920, $\Delta M \operatorname{tgDebt}_{c, 1910-20}$ is the percentage growth in mortgage debt per acre in county $c$ between 1910 and 1920, MtgDebt ${ }_{c, 1920}$ is the value of mortgage debt per acre in county $\mathrm{c}$ in $1920, X_{c, 1920}$ is the vector of county census variables used before with some additions noted below, $B_{i, 1920}$ is a vector of bank-specific control variables for bank $i$ in 1920, $e_{c, t}$ is the robust error term, and the rest of the values retain their previous definitions. Because the asset price boom measures are observed at the county level, we cannot include county-fixed effects and instead expand on the county-level controls to include a vector of Federal Reserve district fixed effects, ${ }^{28}$ the logarithm of crop value in 1920, average rainfall in the county, the standard deviation of rainfall in the county, the logarithm of county land area (in square miles), logarithm distance in miles to the Mississippi River, logarithm distance in miles to the Atlantic Ocean, logarithm distance in miles to the Great Lakes, and logarithm distance in miles to the Pacific Ocean (Rajan and Ramcharan 2015; Haines 2004). The vector of bank-specific variables includes dummies for the entry year of the bank, the logarithm of total assets, loans/assets, capital/assets, and cash/assets in 1920 .

As before, we estimate the model separately for national and state banks. We also estimate the model on the full sample of state or national banks present in 1920 as well as on a reduced sample of banks that were present in 1914 and survived through $1920 .{ }^{29}$ The reduced sample allows us to include each bank's percentage increase in total loans from 1914 to 1920 to test whether rapid loan growth affected closure probability over and above the location-specific factors. Fahlenbrach et al. (2018) document that rapid loan portfolio growth is generally associated with lower average loan quality and lower future stock returns, while other studies

\footnotetext{
${ }^{28}$ Although the borders of many Fed districts align with state boundaries, several states in our sample (i.e., Illinois, Louisiana, Mississippi, Missouri, and Wisconsin) are split between two different Fed districts. Therefore, we include both state and Fed district fixed effects in the model.

${ }^{29}$ Appendix Table A.12 shows the results when we combine state and national banks into a single model and test for differences in their reactions.
} 
have found that rapid loan growth increases a bank's failure risk (e.g., Federal Deposit Insurance Corporation 1997). Thus, even after controlling for bank age, we anticipate that banks with more loan growth during the boom would have been more likely to close during the bust since rapid growth might reflect aggressive lending associated with less screening of borrowers or lower lending standards.

The marginal effects of Equation (3) reported in Table 4 indicate that the probability of a bank closing during 1920-24 was positively correlated with the increase in county farmland value during the 1910 s even after controlling for the balance sheet measures. We estimate that a doubling of farmland value over the 1910s increased a state bank's probability of closing during 1920-24 by 10.8 percentage points and a national bank's probability of closing by 7.2 percentage points. We find no impact of changes in mortgage debt per acre or improved acreage, or of the level of mortgage debt per acre in 1920, on closure probabilities for state banks. However, national banks located in counties with larger improved acreage increases during the 1910s had higher probabilities of closing during 1920-24. Further, our results indicate that for state banks, larger size (measured by the log of total assets), higher capital/assets, and higher cash/assets reduced closure probability, whereas higher loans/assets increased the probability of closing. The results for national banks go in the same directions but are not always statistically significant, likely due to their lower closure rates and fewer observations.

Finally, for both bank types, the year of entry dummies indicate that older banks were much more likely to survive than banks that entered between 1918 and 1920 (i.e., the excluded group). Compared with a bank that opened between 1918 and 1920, a state bank that opened between 1916 and 1918 was 3.3 percent less likely to close, a state bank that opened between 1914 and 1916 was 6.7 percent less likely to close, and a state bank that opened before 1914 was between 4.7 and 8.2 percent less likely to close.

The results for the sample of banks established before 1914 are generally similar to those for all banks present in 1920. The age dummies are no longer statistically significant, indicating that the year of establishment mattered little for banks that opened before 1914. We also find that rapid loan growth during the boom increased a bank's probability of closing during the bust. The estimates indicate that a 76.9 percent increase in loans during 1914-20 (i.e., the average percentage change in bank loans in the sample) would have increased the probability of closure by 1.38 percentage points (about 9 percent relative to the mean closure rate) even after 
controlling for the increase in county farmland value during 1910-20 and bank balance sheet composition in 1920 .

We also examine whether state banking regulations and policies affected closure rates directly (rather than through their effects on bank balance sheets) using interactions with the change in farmland value during 1910-20. If access to the Federal Reserve's discount window provided member banks with a reliable source of liquidity, then they might have been better able to withstand the decline in farmland prices. ${ }^{30}$ Deposit insurance might have increased the probability of bank closure during the 1920s by encouraging greater risk-taking during the boom or as losses eroded bank net worth during the bust. The effect of extended liability on the closure probability is unclear a priori. Although conceivably a deterrent to risk-taking, Grossman (2001) speculates that extended liability gave bankers an incentive to close sooner in order to avoid hitting shareholders with larger losses when banks inevitably failed. Finally, higher capital requirements might be associated with greater buffers for losses as well as higher franchise values.

The results reported in the second and third columns indicate that of the policy variables, only deposit insurance had a statistically significant impact on closure probability. The coefficient estimates indicate that the impact of the increase in land prices during 1910-20 on bank closure probability during 1920-25 was four times larger for banks with insured deposits than for uninsured state banks. The insignificant coefficients on the other regulatory variables suggest that their effects, if any, are captured by the bank balance sheet variables in the model (e.g., higher dollar minimum capital requirements prevented the formation of very small banks as well as new banks, both of which had higher closure rates). The inclusion of these interactions greatly reduces the size and statistical significance of the coefficient on the change in farmland value during 1910-20, however, indicating that the effect of the land boom worked through its impact on bank balance sheets and their interactions with regulation.

We did not include the change in farmland value during 1920-25 in our regressions because of the possibility that bank closures had an impact on local land prices. However, with the explicit understanding that the coefficients are not necessarily causal estimates, we add the percent change in farmland value per acre for 1920-25 and its interaction with the percent change

\footnotetext{
${ }^{30}$ White (2015) argues that the Federal Reserve Bank of Atlanta lent aggressively to reduce bank distress during the early 1920s. Our inclusion of Fed District fixed effects accounts for these types of differences.
} 
in farmland value per acre 1910-20 to Equation (3), reported in Appendix Table A.13. The level variable allows us to observe whether bank closures were sensitive to the farmland price bust, whereas the interaction allows us to test whether the impact of the decline in land prices on bank closure probability depended on the size of the preceding land price boom. The results provide some evidence that the larger the increase in farmland value during the boom, the greater the impact of a given decline in local farmland value per acre on the probability of closing during the bust. Comparing two counties with the average change in farmland value during 1920-25 (i.e., -34.9 percent), a state bank in a county that experienced a 25 percent larger rise in farmland value during the 1910 s was 0.8 percentage points more likely to close in the early-1920s than a state bank located in the other county.

The bank-level analysis provides insight into the dynamics surrounding the interplay of bank and agricultural distress during the 1920s. On a macroeconomic level, the interaction between the boom and the bust made things even worse, at least for state-chartered banks. That said, microeconomic and regulatory factors also played a role. Banks that were established during the war, expanded their loans during the boom, had higher loans/assets, lower capital/assets, or lower cash/assets were more likely to close during the bust. Deposit insurance appears to have made banks particularly vulnerable to the boom and bust in farmland values.

\section{Bank Closures and the Bust}

The previous sections have shown how banks responded to and were affected by the agricultural price shock. In this section, we explore the impact of banking instability on the decline of farmland values after commodity prices collapsed in 1920. Rajan and Ramcharan (2015a) show that, for a given shock to commodity prices, counties with more banks experienced larger increases in farmland value than counties with fewer banks, and subsequently, those counties experienced larger declines in land value through the 1930s and a lower level of land prices as late as $1960 .^{31}$ Further, Rajan and Ramcharan (2016) find that bank suspensions depressed land values during the 1920s. To limit potential endogeneity, Rajan and Ramcharan employ an identification strategy that involves including suspension rates in both the reference county and in neighboring counties in another state in their regression, under the assumption that suspensions in out-of-state counties capture the impact of economic activity and credit demand,

\footnotetext{
${ }^{31}$ In addition to showing similar results for the number of banks in our agricultural county sample, we show in Appendix Table A.14 that loan growth during the 1910s exerted a separate positive effect on farmland value.
} 
whereas in-state suspensions reflect both credit demand and supply effects. By contrast, we exploit our microeconomic data on bank balance sheets to estimate predicted bank closure rates based on predetermined values, which enables us to include all counties (not just those along state borders) in the analysis. We also estimate separately the effects of state-chartered and national bank closures, as well as the dynamics of the boom-bust event.

We estimate the following model to examine how the growth and collapse of banks contributed to the land price bust between 1920 and 1925:

$$
\begin{aligned}
& \Delta \text { LandValue }_{c, 1920-25} \\
& =a+\beta_{1} \Delta \text { CropIndex }_{c, 1919-25}+\beta_{2} \text { SDistresS }_{C, 1920}+\beta_{3} \text { NDistress }_{c, 1920} \\
& +\beta_{4} \Delta \text { LandValue }_{c, 1910-20}+\beta_{5} X_{c, 1920}+s_{s}+e_{c} \text { (4) }
\end{aligned}
$$

where $\Delta$ LandValue $e_{c, 1920-25}$ is percentage change in farmland value per acre for county $c$ from 1920 to $1925, \Delta$ CropIndex $x_{c, 1919-25}$ is the percentage change in the crop price index for county $c$ from 1919 to 1925, SDistress $_{c, 1920}$ and NDistress ${ }_{c, 1920}$ are one of several measures of state or national bank distress described below, and the rest of the variables retain their prior definitions. To capture the effect of the banking sector distress on farmland value over and above the crop price shock, we include three types of bank distress measures in the model. First, we include interactions of the crop price index with the numbers of state and national banks in the county in 1920. Second, we include the percent change in bank loan volume in the county from 1910-20. Finally, we include three direct measures of bank closures: the number of banks that closed between 1920 and 1924, the value of assets in 1920 of those banks, and the fraction of a county's assets in 1920 made up by the banks that subsequently closed.

The results, reported in Table 5, reveal a positive impact of changes in the crop price index during 1919-25 on changes in farmland values during the bust. We also find a negative impact of changes in farmland value per acre during the boom on changes in farmland value during the bust. That is, controlling for the fall in crop prices after 1919, counties with larger increases in farmland values during the 1910s suffered larger declines in land values during 1920-25. Our estimates indicate that a county with an additional 10 percentage point increase in farmland value during the 1910s had a 3.1 percentage point larger decline in land value in the 1920s (i.e., about 10 percent of the mean decline in the sample) relative to another county.

The presence of banks or the growth in bank loans might have had an impact to the extent that they contributed to rising farmland values during the boom. However, we find no direct 
impact of the number of banks in 1920, the interaction of the number of banks in 1920 with the crop price change 1919-25, or the growth in bank loans during 1910-20 on the change in farmland values during 1920-25.

By contrast, changes in local credit supply resulting from state bank failures or other closures seem to have had an impact. Results reported in columns (3) through (5) indicate that the change in farmland value during 1920-25 is correlated with each of the three measures of state bank closures. For example, a one standard deviation higher number of state bank closures (i.e., 1.56 additional closures) is associated with 2 percentage point larger decline in land value. Similarly, the decline in land value is negatively correlated with the amount of assets in closed state banks and the percentage of a county's banking assets in closed state banks. By contrast, we find no evidence of a link between farmland value and national bank closures during the bust. As previously noted, national banks generally did not respond with aggressive lending during the land price boom, and few closed during the subsequent bust.

The number of closures and assets in closed banks are the most accurate measures of bank distress, but are also likely endogenous to the decline in farmland value. Because of this, we report additional specifications in Table 6 that make use of the state bank closure regression reported in column (2) of Table 4 to generate an arguably exogenous measure of predicted state bank closure risk. ${ }^{32}$ The bank closure regressions contain a variety of bank-level variables that reliably predict bank closure and should otherwise be uncorrelated with the decline in farmland values in the early 1920s. Specifically, the closure regressions include measures of each bank's balance sheet and age in 1920. The county-level model controls for changes in the crop price index, previous changes in farmland values, location-fixed effects, and the host of other countylevel control variables included in the closure model. Hence, the remaining variation in the predicted probability of closure for each bank is driven exclusively by the bank's balance sheet composition and age in 1920. To move from the bank-level to the county-level, we sum the predicted closure probabilities for each bank in a county.

\footnotetext{
${ }^{32}$ We focus on state bank closures because we found that changes in farmland value were not correlated with national bank closures. Also, because few national banks closed during the bust, the explanatory power of the balance sheet items and regulatory interactions are much weaker. The results are similar if we restrict the sample to older state banks and include the percentage growth in loans 1914-20 (as in column (3) of Table 4) or if we include regulatory interactions (as in column (2) of Table 4).
} 
In column (2) of Table 6, we provide estimates from a reduced form model that replaces the number of state bank closures with the sum of the predicted closure probabilities. ${ }^{33}$ The coefficient on the predicted closure probability is slightly larger but not significantly different from the OLS estimate in column (1). In column (3), we formalize the IV specification by utilizing a two-stage least squares model that instruments for the number of state bank closures using the sum of predicted closure probabilities of state banks in the county. ${ }^{34}$ The coefficient on the instrumented number of state bank closures in column (3) is larger than coefficient on raw number of state bank closures in column (1). The same one standard deviation increase the number of state bank closures is associated with a 4 percentage point decrease in farmland value. The IV approach thus yields the same result as the OLS regressions: counties experiencing more state banks closures saw additional reductions in farmland value during the 1920s.

\section{Conclusion}

Banks are often intertwined with asset price booms and busts, as the financial crisis of 2008-09 and the preceding subprime mortgage boom demonstrated (e.g., Mian and Sufi 2009; Glaeser et al. 2012; Gorton and Metrick 2012). Historical studies can be valuable for revealing fundamental relationships and the effects of different policies that might not be apparent in complex modern environments, however, and for evidence about the generality of relationships observed in the recent past. The World War I agricultural boom and post-war bust is a particularly useful episode for studying the interrelationship between banks and asset prices. Triggered by the collapse of European agriculture during the war, rapidly rising commodity prices ignited a farmland price boom in the United States. Rajan and Ramcharan (2015a) show that the availability of credit contributed to the boom in land values and mortgage debt at the county-level. Here, using bank-level data, we show how the banking system became enmeshed in the boom. While older banks increased their lending to accommodate rising credit demand, new banks were established and expanded even more aggressively. Similar to the "shadow" banks of the modern era, state-chartered banks responded more strongly to the asset boom than did more tightly regulated national banks. State banking regulations and policies influenced the extent to which banks of both types responded to the boom, however, with higher minimum

\footnotetext{
${ }^{33}$ As shown in Appendix Table A.15, the results are similar if we simply count the number of state banks that had a predicted closure probability over 5 percent.

${ }^{34}$ As might be expected from Table 4, the sum of the predicted closure probabilities strongly predicts the actual number of state bank closures in the first stage. Using the method employed by Stock and Yogo (2005), the Kleibergen-Paap Wald statistic rejects the hypothesis of a weak instrument at the 1 percent-level.
} 
capital requirements deterring bank entry and loan growth, and deposit insurance encouraging more aggressive lending. The World War I asset price boom thus provides supporting evidence for studies of modern crises as well as a micro-level view of the macroeconomic dynamics found in broader studies of asset booms and busts.

The collapse in land values also affected banks. When farm output and land prices collapsed after the war, banks that opened during the boom, banks with weak balance sheets, and banks that had lent most aggressively during the boom were more likely to fail or be acquired than other banks. Our results thus support studies on modern times that find that banks with inexperienced lenders or aggressive loan growth perform worse than other banks when fundamentals sour. Further, our study provides new evidence that deposit insurance was destabilizing in that it amplified the effect of the asset boom on bank closure probabilities when farm prices subsequently collapsed. Bank closures, and by extension banking policies, also played a role in exacerbating the collapse of farmland prices in the 1920s. Controlling for the change in crop prices, counties with more bank closures saw larger declines in land prices. Thus, banking instability made the collapse of asset prices worse than it would have otherwise been.

The historical episode offers many lessons for policymakers. First, policies that inhibit bank scale and diversification can make a banking system prone to instability in the face of asset price shocks. ${ }^{35}$ For example, throughout much of the $19^{\text {th }}$ and $20^{\text {th }}$ centuries, anti-branching laws gave the United States an unstable, crisis-prone banking system comprised of small unit banks, unlike the more stable banking system of Canada and other countries with large, diversified banks (e.g., Bordo et al. 1994; Grossman 2010). Although the United States now permits interstate branch banking, the lingering effects of past restrictions were apparent in the high failures rates of banks located in regions with relatively extreme fluctuations in house prices during the financial crisis of 2008-09 (Aubuchon and Wheelock 2010), and some limits on geographic expansion remain. ${ }^{36}$ Further, various restrictions on bank activities implemented after the crisis, such as the Volcker Rule, might actually increase bank asset or trading risk (Keppo and Korte 2018).

\footnotetext{
${ }^{35}$ Numerous studies find that even the largest banks face increasing returns to scale (e.g., Wheelock and Wilson 2012; Hughes and Mester 2013), though there may be tradeoffs, such as reduced competition or greater systemic risk, if banks are permitted unlimited size (see Mester 2008 for discussion).

${ }^{36}$ For example, state and federal banking laws cap the percentage of a state's deposits that a bank can obtain through acquisitions.
} 
Second, regulators need to be mindful of the tendency for aggressive lending among newly-established banks and avoid policies that encourage excessive risk taking, especially among new entrants. Third, our results indicate that entry barriers in the form of high minimum capital required to obtain a bank charter promoted a more stable banking system, while mispriced deposit insurance had the opposite effect. Our research thus supports studies finding that erosion of entry barriers reduces bank charter values and promote instability, especially when coupled with deposit insurance (e.g., Keeley 1990; Laeven and Levine 2009). Finally, the episode provides evidence of how banking system instability can exacerbate asset price booms and busts, and serves as a reminder that regulations and other policies that influence the stability of banking systems can ultimately affect the stability of asset prices and hence real activity.

\section{References}

Adams, Robert M. and Dean F. Amel. "The Effects of Past Entry, Market Consolidation, and Expansion by Incumbents on the Probability of Entry in Banking." Review of Industrial Organization 48, 2016, pp. 95-118.

Adams, Robert M. and Jacob Gramlich. "Where Are All the New Banks? The Role of Regulatory Burden in New Bank Formation." Review of Industrial Organization 48, 2016, pp. 181-208.

Alston, Lee J. "Farm Foreclosures in the United States during the Interwar Period." Journal of Economic History 43, 1983, pp. 885-903.

Alston, Lee J., Wayne A. Grove, and David C. Wheelock. "Why Do Banks Fail? Evidence from the 1920s." Explorations in Economic History 31, 1994, pp. 409-431.

Anderson, Haelim, Charles W. Calomiris, Matthew Jaremski, and Gary Richardson. "Liquidity Risk, Bank Networks, and the Value of Joining the Federal Reserve System." Journal of Money, Credit, and Banking Vol 50, 2018, pp. 173-201.

Aubuchon, Craig P. and David C. Wheelock. "The Geographic Distribution and Characteristics of U.S. Bank Failures, 2007-2010: Do Bank Failures Still Reflect Local Economic Conditions?" Federal Reserve Bank of St. Louis Review 92 (5), Sept/Oct 2010, pp. 395 415 .

Barth, James R., Gerard Caprio, and Ross Levine, Rethinking Bank Supervision and Regulation: Until Angels Govern (Cambridge University Press, Cambridge), 2006.

Benmelech, Efraim, and Tobias J. Moskowitz. "The political economy of financial regulation: evidence from US state usury laws in the 19th century." Journal of Finance 65 (3), 2010, pp. 1029-1073. 
Berger, Allen N. and Gregory F. Udell. "The Institutional Memory Hypothesis and the Procyclicality of Bank Lending Behavior." Journal of Financial Intermediation 13, 2004, pp. 458-495.

Bernanke, Ben S. "The Global Savings Glut and the U.S. Current Account Deficit." The Homer Jones Lecture, Federal Reserve Bank of St. Louis, April 14, 2005.

Board of Governors of the Federal Reserve System. All Bank Statistics 1896-1955. Washington, D.C., 1959.

Board of Governors of the Federal Reserve System. Banking and Monetary Statistics 1914-1941. Washington, D.C., 1943.

Bordo, Michael D., Hugh Rockoff, and Angela Redish. "The U.S. Banking System from a Northern Exposure: Stability versus Efficiency." Journal of Economic History 54 (2), June 1994, pp. 325-41.

Borio, Claudio E. V. and Philip William Lowe. "Asset Prices, Financial and Monetary Stability: Exploring the Nexus.” BIS Working Paper No. 114, July 2002.

Calomiris, Charles W. "Regulation, Industrial Structure, and Instability in U.S. Banking: An Historical Perspective," in Charles W. Calomiris, ed. U.S. Bank Deregulation in Historical Perspective. Cambridge: Cambridge University Press, 2000.

Calomiris, Charles W. "Do Vulnerable Economies Need Deposit Insurance?" In Philip Brock, ed., If Texas Were Chile, A Primer on Banking Reform. San Francisco: Sequoia Institute, 1992, pp. 237-314.

Calomiris, Charles W., and Matthew Jaremski. "Deposit Insurance: Theories and Facts." Annual Review of Financial Economics 8, 2016, 97-120.

Calomiris, Charles W., and Matthew Jaremski. "Stealing deposits: deposit insurance, risk-taking and the removal of market discipline in early 20th century banks." Journal of Finance, forthcoming, 2019.

Campello, Murillo, John R. Graham, and Campbell R. Harvey. "The Real Effects of Financial Constraints: Evidence from a Financial Crisis." Journal of Financial Economics 97 (3), 2010, pp. 470-87.

Carlson, Mark, Sergio Correia, and Stephan Luck. "The Effects of Banking Competition on Growth and Financial Stability: Evidence from the National Banking Era." Working paper, June 25, 2018.

Carlson, Mark and David C. Wheelock. "Did the Founding of the Federal Reserve Affect the Vulnerability of the Interbank System to Contagion Risk?" Journal of Money, Credit and Banking 58 (8), December 2018, pp. 1711-1750 
Carter, Susan, Sigmund Carter, Scott, Haines, Michael, Olmstead, Alan, Sutch, Richard, and Wright, Gavin. Historical Statistics of the United States: Earliest Times to the Present, Millennial Edition. New York: Cambridge University Press, 2006, Tables 4-39 to 4-88.

Case, Karl E. and Robert J. Shiller. "Is There a Bubble in the Housing Market?" Brookings Papers on Economic Activity 2, 2003, pp. 299-342.

Chodorow-Reich, Gabriel. "The Employment Effects of Credit Market Disruptions: Firm-level Evidence from the 2008-9 Financial Crisis.” Quarterly Journal of Economics 129 (1), 2014, pp. 1-59.

Cole, Rebel A. and Lawrence J. White. "Déjà vu All Over Again: The Causes of U.S. Commercial Bank Failures This Time Around." Journal of Financial Services Research 42, 2012, pp. 5-29.

Dehejia, Rajeev and Adriana Lleras-Muney. "Financial Development and Pathways of Growth: State Branching and Deposit Insurance Laws in the United States, 1900-1940." Journal of Law and Economics 50, May 2007, pp. 239-272.

Dell'Ariccia, Giovanni, Deniz Igan, and Luc Laeven. "Credit Booms and Lending Standards: Evidence from the Subprime Mortgage Market." Journal of Money, Credit and Banking 44 (2-3), March-April 2012, pp. 368-84.

DeYoung, Robert. "De Novo Bank Exit." Journal of Money, Credit and Banking 35 (5), Oct. 2003, pp. 711-728.

Demirgüç-Kunt, Asli, and Enrica Detragiache. "Does Deposit Insurance Increase Banking System Stability? An Empirical Investigation.” Journal of Monetary Economics 49, 2002, pp. 1373-1406.

Demirgüç-Kunt, Asli, and Harry Huizinga, 2004, "Market discipline and deposit insurance." Journal of Monetary Economics 51, 2004, pp. 375-399.

Eichengreen, Barry, and Kris J. Mitchener. "The Great Depression as a credit boom gone wrong." Research in Economic History 22, 2004, pp. 183-237.

Fahlenbrach, Rüdiger, Robert Prilmeier, and René M. Stulz. "Why Does Fast Loan Growth Predict Poor Performance for Banks?” Review of Financial Studies 31 (3), 2018, pp. 1014-1063.

Federal Deposit Insurance Corporation. History of the Eighties - Lessons for the Future, Volume 1: "The Banking Crises of the 1980s and Early 1990s: Summary and Implications." 1997 (https://www.fdic.gov/bank/historical/history/).

Federal Deposit Insurance Corporation. Annual Report for the Year Ended December 31, 1956. Washington, DC, 1956.

Federico, Giovanni, and Karl Gunnar Persson. "Market integration and convergence in the world wheat market, 1800-2000." The new comparative economic history: essays in honor of Jeffrey G. Williamson. 2007: pp. 87-113. 
Flood, Mark D. “The Great Deposit Insurance Debate," Federal Reserve Bank of St. Louis Review 74, 1992, pp. 51-77.

Geanakoplos, John. “The Leverage Cycle.” NBER Macroeconomics Annual 24, 2010, pp. 1-65.

Gertler, Mark and Simon Gilchrist. "What Happened: Financial Factors in the Great Recession." Journal of Economic Perspectives 32 (3), Summer 2018, pp. 3-30.

Glaeser, Edward, Joshua Gottlieb, and Joseph Gyourko. "Can cheap credit explain the housing boom?" Housing and the financial crisis. University of Chicago Press 2012, pp. 301-359.

Gorton, Gary and Andrew Metrick. "Getting Up to Speed on the Financial Crisis: A OneWeekend-Reader's Guide.” Journal of Economic Literature 50 (1), 2012, pp. 128-150.

Grossman, Richard S. Unsettled Account: The Evolution of Banking in the Industrialized World Since 1800. Princeton: Princeton University Press, 2010.

Grossman, Richard S. "Double Liability and Bank Risk Taking." Journal of Money, Credit and Banking 33 (2), part 1, May 2001, pp. 143-59.

Haines, Michael R. Historical, Demographic, Economic, and Social Data: The United States, 1790-2000. ICPSR Study 2896. Ann Arbor, MI: Inter-university Consortium for Political and Social Research, 2004.

Horton, Donald C., Harald C. Larsen, and Norman J. Wall. "Farm-Mortgage Credit Facilities in the United States." U.S. Department of Agriculture, Bureau of Agricultural Economics miscellaneous publication no. 478, 1942.

Hughes, Joseph P. and Loretta J. Mester. "Who Said Large Banks Don’t Experience Scale Economies?” Journal of Financial Intermediation 22, 2013, pp. 559-585.

Ivashina, Victoria and David Scharfstein. "Bank Lending During the Financial Crisis of 2008." Journal of Financial Economics 97 (3), 2010, pp. 319-38.

Jaremski, Matthew. National Bank Balance Sheets. Unpublished database collected from Annual Report of the Comptroller of the Currency (various), 2013.

Jaremski, Matthew and Price Fishback. "Did Inequality in Farm Sizes Lead to Suppression of Banking and Credit in the Late Nineteenth Century?" Journal of Economic History 78, 2018, pp. 155-195.

Keeley, Michael. "Deposit Insurance, Risk, and Market Power in Banking." American Economic Review 80, 1990, pp. 1183-1200.

Keppo, Jussi and Josef Korte. "Risk Targeting and Policy Illusions-Evidence from the Announcement of the Volcker Rule." Management Science 64, 2018, pp. 215-234.

Kindleberger, Charles .P. Manias, Panics and Crashes. New York: Basic Books, 1978.

Kiyotaki, Nobuhiro and John Moore. “Credit Cycles.” Journal of Political Economy 105 (2), 1997, pp. 211-48. 
Laeven, Luc, and Ross Levine. "Bank Governance, Regulation and Risk Taking." Journal of Financial Economics 93, 2009, pp. 259-275.

Loutskina, Elena and Philip Strahan. "Securitization and the Declining Impact of Bank Finance on Loan Supply: Evidence from Mortgage Acceptance Rates.” Journal of Finance 64, 2009, pp. 861-89.

Meltzer, Allan H. A History of the Federal Reserve. Volume 1, 1913-1951. Chicago: University of Chicago Press, 2003.

Mester, Loretta J. "Optimal Industrial Structure in Banking." Federal Reserve Bank of Philadelphia working paper no. 08-2, 2008.

Mian, Atif and Amir Sufi. "The Consequences of Mortgage Credit Expansion: Evidence from the U.S. Mortgage Default Crisis." Quarterly Journal of Economics 124, 2009, pp. 14491496.

Minnesota Population Center. National Historical Geographic Information System: Pre-release Version 0.1. Minneapolis, MN: University of Minnesota, 2004 (http://www.nhgis.org).

Minsky, Hyman. Stabilizing an Unstable Economy. New Haven: Yale University Press, 1986.

Mitchener, Kris and Matthew Jaremski. "The Evolution of Bank Supervisory Institutions: Evidence from American States.” Journal of Economic History 75, 2015, pp. 819-859.

Nuňo, Gala and Carlos Thomas. "Bank Leverage Cycles." American Economic Journal: Macroeconomics 9 (2), 2017, pp. 32-72.

Office of the Comptroller of the Currency. Annual Report of the Comptroller of the Currency (various years). Washington: Government Printing Office.

Rajan, Raghuram. "Why Bank Credit Policies Fluctuate: A Theory and Some Evidence." Quarterly Journal of Economics 109 (2), 1994, pp. 399-441.

Rajan, Raghuram, and Rodney Ramcharan. "Local Financial Capacity and Asset Values: Evidence from Bank Failures.” Journal of Financial Economics 120, 2016, pp. 229-251.

Rajan, Raghuram and Rodney Ramcharan. "The Anatomy of a Credit Crisis: The Boom and Bust in Farm Land Prices in the United States in the 1920s." American Economic Review 105, 2015a, pp. 1439-77.

Rajan, Raghuram, and Rodney Ramcharan. "Constituencies and Legislation: The Fight Over the McFadden Act of 1927." Management Science 62.7, 2015b, pp. 1843-1859.

Reinhart, Carmen M. and Kenneth S. Rogoff. This Time is Different: Eight Centuries of Financial Folly. Princeton: Princeton University Press, 2009.

Schularick, Moritz, and Alan M. Taylor. "Credit Booms Gone Bust: Monetary Policy, Leverage Cycles, and Financial Crises, 1870-2008." American Economic Review 102, 2012, pp. 1029-61. 
Sharp, Paul, and Jacob Weisdorf. "Globalization revisited: Market integration and the wheat trade between North America and Britain from the eighteenth century." Explorations in Economic History 50, 2013, 88-98.

Stock, James H., and Motohiro Yogo. "Testing for Weak Instruments in Linear IV Regression," in James H. Stock and Donald W. K. Andrews, eds., Identification and Inference for Econometric Models: Essays in Honor of Thomas J Rothenberg. New York: Cambridge University Press, 2005.

Taylor, John B. "Getting Back on Track: Macroeconomic Policy Lessons from the Financial Crisis.” Federal Reserve Bank of St. Louis Review 92 (3), May/June 2010, pp. 165-76.

United States Department of Agriculture. Yearbook 1921. Washington: U.S. Government Printing Office, 1922.

Wheelock, David C. and Subal C. Kumbhakar. "Which Banks Chose Deposit Insurance? Adverse Selection and Moral Hazard in a Voluntary Insurance System." Journal of Money, Credit and Banking 27, 1995, pp. 186-201.

Wheelock, David C. and Paul W. Wilson. "Do Large Banks have Lower Costs? New Estimates of Returns to Scale for U.S. Banks.” Journal of Money, Credit and Banking 44, 2012, pp. 171-199.

Wheelock, David C. and Paul W. Wilson. "Why Do Banks Disappear? The Determinants of U.S. Bank Failures and Acquisitions." Review of Economics and Statistics 82, 2000, pp. 127 138.

Wheelock, David C. and Paul W. Wilson. "Explaining Bank Failures: Deposit Insurance, Regulation, and Efficiency." Review of Economic and Statistics 77, 1995, pp. 689-700.

White, Eugene N. "Protecting Financial Stability in the Aftermath of World War I: The Federal Reserve Bank of Atlanta's Dissenting Policy". National Bureau of Economic Research Working Paper w21341, 2015.

White, Eugene N. "A Reinterpretation of the Banking Crisis of 1930." Journal of Economic History 44 (1), March 1984, pp. 119-38.

White, Eugene N. The Regulation and Reform of the American Banking System, 1900 to 1929. Princeton: Princeton University Press, 1983.

Williamson, Jeffrey G. "Globalization, convergence, and history." The Journal of Economic History 56, 1996, pp. 277-306. 
Figure 1: U.S. Crop Prices (1908-1925)

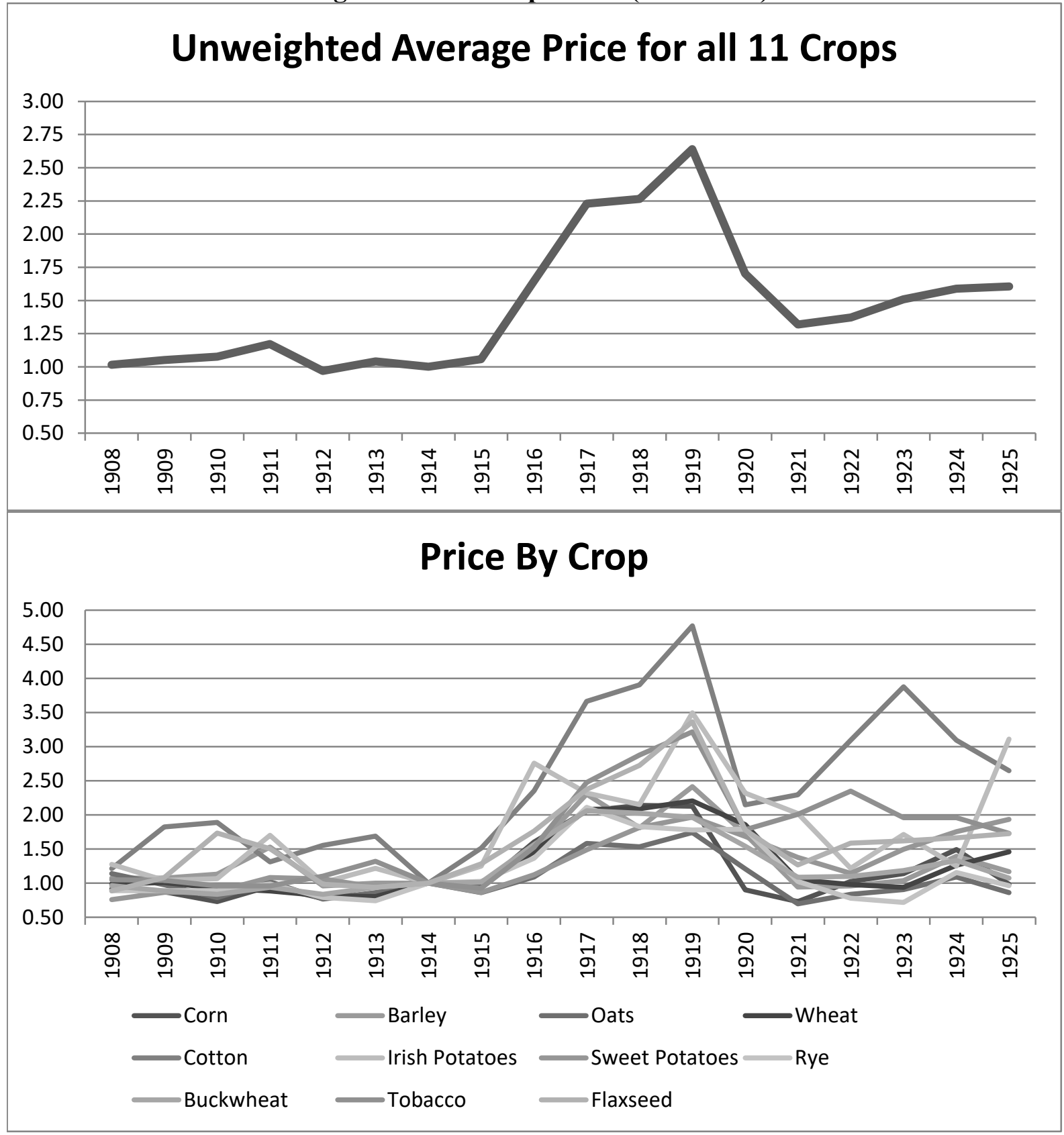

Notes: The figure shows nation-wide prices of 11 major crops. The top panel plots an unweighted annual average of all crops; the bottom panel plots the individual prices of each crop. All prices are normalized to " $1 "$ in 1914. Price data are from Carter et al. (2006). 
Figure 2: County-Level Changes in Crop and Farm Value

Panel A: Crop Price Index By County in 1919

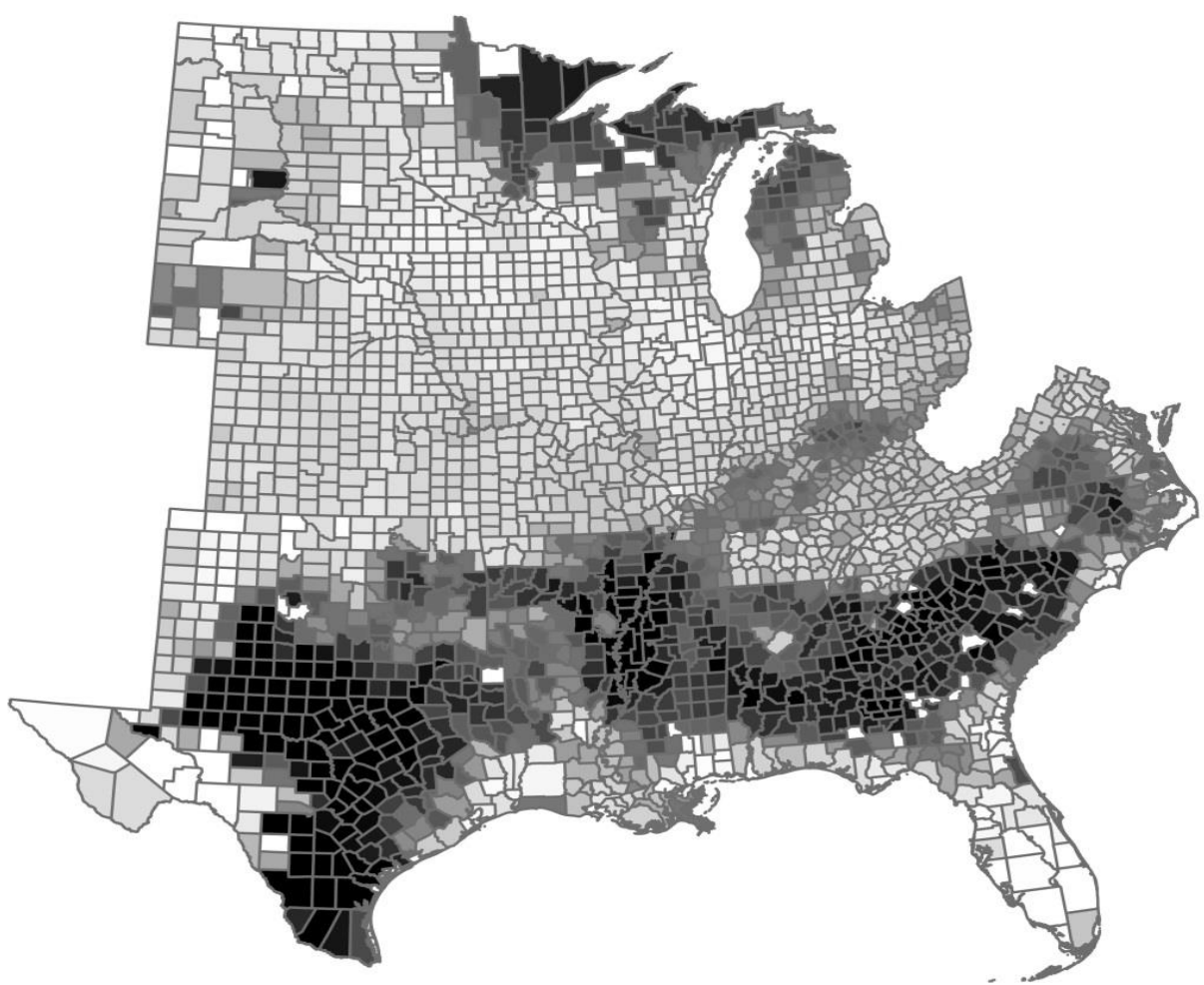

Panel B: \% Change of Farmland Value Per Acre (1910-20)

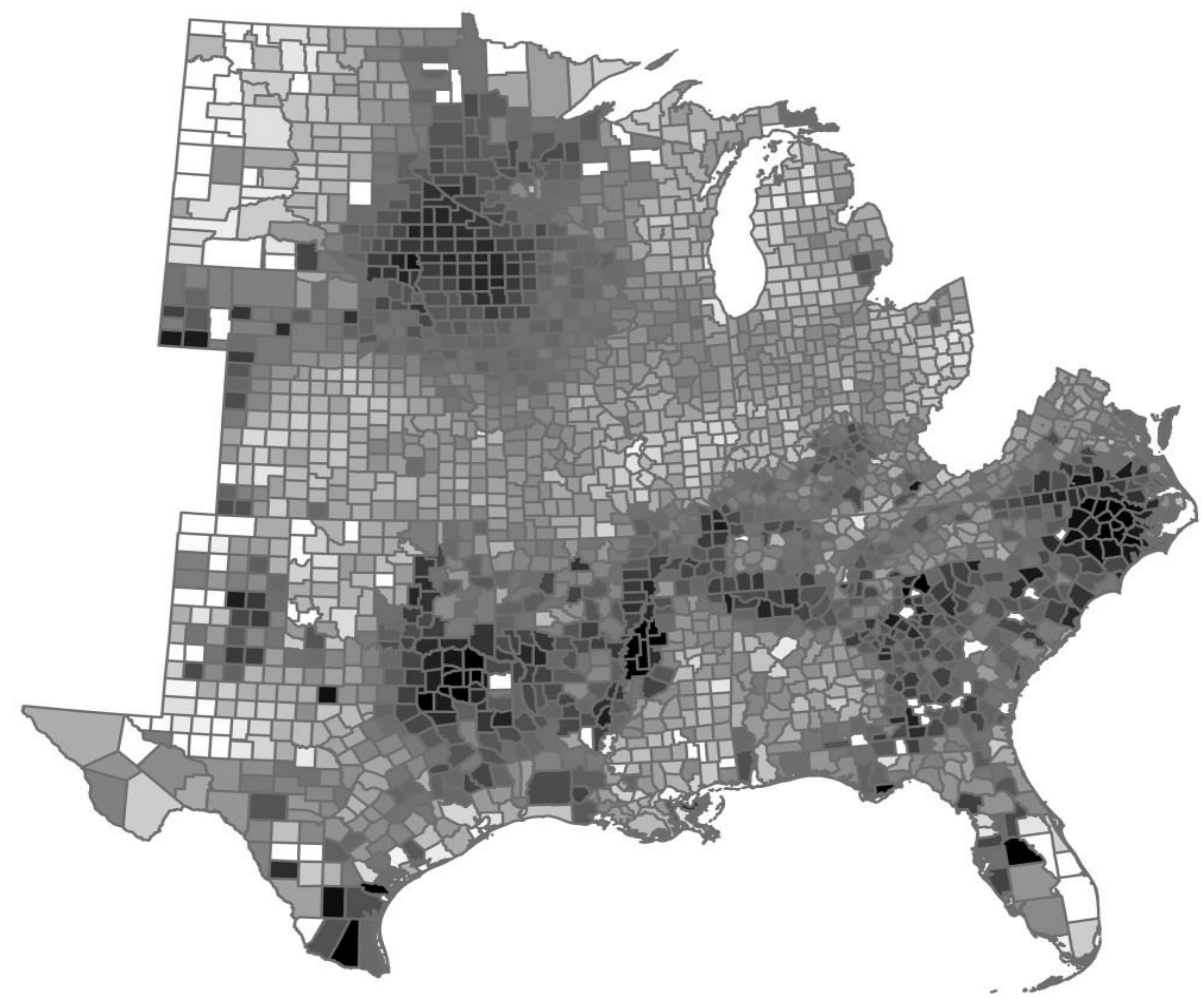

Notes: The map in the top panel displays the county-level crop price index in 1919. The map in the bottom panel displays the percentage change in farmland value per acre (1910-20) from Haines (2004). In both maps dark colors denotes higher values whereas light colors denotes lower values. Boundaries were obtained from Minnesota Population Center (2004). We provide information on all states (not just those in our sample) in order to show that states with available data display similar patterns to those that do not. 
Table 1: Determinants of Bank Entry (1910-1920)

\begin{tabular}{lccccc}
\hline & \multicolumn{3}{c}{ \# of New Banks In Period } \\
\cline { 2 - 3 } \cline { 5 - 6 } Crop Price Index At Start of & \multicolumn{2}{c}{ State Banks } & & \multicolumn{2}{c}{ National Banks } \\
\cline { 2 - 3 } Period & $0.861^{* * *}$ & $1.005^{* * *}$ & & $-0.853^{* *}$ & -0.193 \\
Extended Liability * Crop Price & {$[0.133]$} & {$[0.141]$} & & {$[0.366]$} & {$[0.385]$} \\
Index At Start of Period & & 0.024 & & & -0.351 \\
Min Cap> $\$ 10,000^{*}$ Crop Price & & {$[0.085]$} & & & {$[0.214]$} \\
Index At Start of Period & & $-0.516^{* * *}$ & & $-0.620^{* * *}$ \\
Deposit Insurance * Crop Price & & {$[0.084]$} & & & {$[0.196]$} \\
Index At Start of Period & & -0.127 & & & -0.331 \\
County Controls? & & {$[0.091]$} & & & {$[0.221]$} \\
County Fixed Effects? & Yes & Yes & & Yes & Yes \\
Regulation Controls? & Yes & Yes & & Yes & Yes \\
Year Fixed Effects? & Yes & Yes & & Yes & Yes \\
Observations & Yes & Yes & & Yes & Yes \\
\hline
\end{tabular}

Notes: The table presents the results of a negative binomial regression. The dependent variable is the number of new banks entering the county in each period. Each observation is a county and each county is observed every two years. Counties with no entry over the period are dropped from the estimation. Only counties located in the Midwest, Great Plains, or South with consistent bank-level data published are included. The sample also excludes locations with cities over 25,000 population, fewer than 250 farms, or fewer than 15,000 improved farm acres. County-level controls include the logarithms of county population and manufacturing output per person, the fraction of county population living in a city or town of 2,500 or more persons, the fractions of county population that are non-white, illiterate, or 15 years of age or younger, the number of national banks in the county at the beginning of the period, and the number of state banks in the county at the beginning of the period. Regulation controls include the presence of Extended liability, deposit insurance, or minimum capital above $\$ 10,000$ for state banks. Robust standard errors clustered by county are presented in parentheses below the coefficients. * denotes significance at $10 \% ; * *$ at $5 \%$ level and $* * *$ at $1 \%$ levels. 
Table 2: Effect of Crop Price Shock on State Bank Balance Sheets (1908-1920)

\begin{tabular}{|c|c|c|c|c|c|c|c|c|c|}
\hline \multirow[b]{2}{*}{ Crop Price Index } & \multicolumn{3}{|c|}{ Ln(Assets) } & \multicolumn{3}{|c|}{ Ln(Loans) } & \multicolumn{3}{|c|}{ Loans/Assets } \\
\hline & $\begin{array}{c}0.230^{* * * *} \\
{[0.019]}\end{array}$ & $\begin{array}{c}0.230^{* * * *} \\
{[0.018]}\end{array}$ & $\begin{array}{c}0.220^{* * *} \\
{[0.020]}\end{array}$ & $\begin{array}{c}0.237^{* * *} \\
{[0.021]}\end{array}$ & $\begin{array}{c}0.232^{* * *} \\
{[0.021]}\end{array}$ & $\begin{array}{c}0.215^{* * *} \\
{[0.022]}\end{array}$ & $\begin{array}{c}0.004 \\
{[0.006]}\end{array}$ & $\begin{array}{c}0.001 \\
{[0.006]}\end{array}$ & $\begin{array}{l}-0.005 \\
{[0.007]}\end{array}$ \\
\hline $\begin{array}{l}\text { Crop Price Index * } \\
\text { Young Bank }\end{array}$ & & $\begin{array}{l}-0.001 \\
{[0.009]}\end{array}$ & $\begin{array}{c}0.001 \\
{[0.009]}\end{array}$ & & $\begin{array}{c}0.039^{* * *} \\
{[0.012]}\end{array}$ & $\begin{array}{c}0.041^{* * *} \\
{[0.011]}\end{array}$ & & $\begin{array}{c}0.024 * * * \\
{[0.003]}\end{array}$ & $\begin{array}{c}0.024 * * * \\
{[0.003]}\end{array}$ \\
\hline $\begin{array}{l}\text { Fed Member * Crop } \\
\text { Price Index }\end{array}$ & & & $\begin{array}{c}-0.024 \\
{[0.022]}\end{array}$ & & & $\begin{array}{c}-0.001 \\
{[0.028]}\end{array}$ & & & $\begin{array}{l}0.021^{* *} \\
{[0.009]}\end{array}$ \\
\hline $\begin{array}{l}\text { Extended Liability * } \\
\text { Crop Price Index }\end{array}$ & & & $\begin{array}{c}0.062 * * * \\
{[0.011]}\end{array}$ & & & $\begin{array}{c}0.098^{* * *} * \\
{[0.014]}\end{array}$ & & & $\begin{array}{c}0.019 * * * \\
{[0.005]}\end{array}$ \\
\hline $\begin{array}{l}\text { Min Cap }>\$ 10,001 * \\
\text { Crop Price Index }\end{array}$ & & & $\begin{array}{c}-0.122 * * * \\
{[0.011]}\end{array}$ & & & $\begin{array}{c}-0.168 * * * \\
{[0.012]}\end{array}$ & & & $\begin{array}{c}-0.021 * * * \\
{[0.004]}\end{array}$ \\
\hline $\begin{array}{l}\text { Insured Bank * } \\
\text { Crop Price Index }\end{array}$ & & & $\begin{array}{c}0.099 * * * \\
{[0.010]}\end{array}$ & & & $\begin{array}{c}0.085^{* * *} \\
{[0.013]}\end{array}$ & & & $\begin{array}{c}-0.004 \\
{[0.004]}\end{array}$ \\
\hline $\begin{array}{l}\text { Crop Price Index * } \\
\text { Yr }=1918\end{array}$ & $\begin{array}{l}0.074 * * \\
{[0.036]}\end{array}$ & $\begin{array}{l}0.074 * * \\
{[0.036]}\end{array}$ & $\begin{array}{c}0.042 \\
{[0.037]}\end{array}$ & $\begin{array}{c}-0.276^{* * * *} \\
{[0.046]}\end{array}$ & $\begin{array}{c}-0.277 * * * \\
{[0.046]}\end{array}$ & $\begin{array}{c}-0.302 * * * \\
{[0.044]}\end{array}$ & $\begin{array}{c}-0.206^{* * * *} \\
{[0.018]}\end{array}$ & $\begin{array}{c}-0.206^{* * * *} \\
{[0.018]}\end{array}$ & $\begin{array}{c}-0.204 * * * \\
{[0.018]}\end{array}$ \\
\hline County Controls? & Yes & Yes & Yes & Yes & Yes & Yes & Yes & Yes & Yes \\
\hline ls? & Yes & Yes & Yes & Yes & Yes & Yes & Yes & Yes & Yes \\
\hline Bank Fixed Effects? & Yes & Yes & Yes & Yes & Yes & Yes & Yes & Yes & Yes \\
\hline Year & Yes & Yes & Yes & Yes & Yes & Yes & Yes & Yes & Yes \\
\hline Obse & 57038 & 57038 & 57038 & 57038 & 57038 & 57038 & 57038 & 57038 & 57038 \\
\hline & 0.756 & 0.756 & 0.763 & 0.694 & 0.694 & 0.703 & 0.142 & 0.143 & 0.146 \\
\hline Crop Price Index & $\begin{array}{c}\text { (Capita } \\
-0.030^{* * *} \\
{[0.004]}\end{array}$ & $\begin{array}{c}\text { I+Surplus) } \\
-0.028^{* * *} \\
{[0.004]}\end{array}$ & $\begin{array}{c}\text { /Assets } \\
-0.029^{* * *} \\
{[0.004]}\end{array}$ & $\begin{array}{c}\mathbf{C a s h}+\mathbf{D u} \mathbf{u} \\
0.013^{* *} \\
{[0.005]}\end{array}$ & 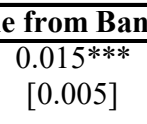 & $\begin{array}{c}\text { k)/ Assets } \\
0.026^{* * *} \\
{[0.006]}\end{array}$ & $\begin{array}{c}\text { Bonds } \\
-0.030^{* * *} \\
{[0.006]}\end{array}$ & $\begin{array}{c}\text { and Stocks } \\
-0.031^{* * *} \\
{[0.006]}\end{array}$ & $\begin{array}{c}\text { Assets } \\
-0.010^{* *} \\
{[0.005]}\end{array}$ \\
\hline $\begin{array}{l}\text { Crop Price Index * } \\
\text { Young Bank }\end{array}$ & & $\begin{array}{c}-0.013^{* * *} \\
{[0.002]}\end{array}$ & $\begin{array}{c}-0.014 * * * \\
{[0.002]}\end{array}$ & & $\begin{array}{c}-0.016^{* * *} \\
{[0.003]}\end{array}$ & $\begin{array}{c}-0.016^{* * *} \\
{[0.003]}\end{array}$ & & $\begin{array}{c}0.002 \\
{[0.002]}\end{array}$ & $\begin{array}{c}0.003 \\
{[0.002]}\end{array}$ \\
\hline $\begin{array}{l}\text { Fed Member * Crop } \\
\text { Price Index }\end{array}$ & & & $\begin{array}{l}0.008 * * \\
{[0.004]}\end{array}$ & & & $\begin{array}{c}-0.019 * * * \\
{[0.006]}\end{array}$ & & & $\begin{array}{c}-0.004 \\
{[0.005]}\end{array}$ \\
\hline $\begin{array}{l}\text { Extended Liability * } \\
\text { Crop Price Index }\end{array}$ & & & $\begin{array}{c}0.003 \\
{[0.002]}\end{array}$ & & & $\begin{array}{c}-0.021 * * * \\
{[0.004]}\end{array}$ & & & $\begin{array}{c}-0.009 * * * \\
{[0.002]}\end{array}$ \\
\hline $\begin{array}{l}\text { Min Cap }>\$ 10,001 * \\
\text { Crop Price Index }\end{array}$ & & & $\begin{array}{l}0.005 * * \\
{[0.002]}\end{array}$ & & & $\begin{array}{l}0.007 * * \\
{[0.003]}\end{array}$ & & & $\begin{array}{c}-0.036 * * * \\
{[0.004]}\end{array}$ \\
\hline $\begin{array}{l}\text { Insured Bank * } \\
\text { Crop Price Index }\end{array}$ & & & $\begin{array}{c}-0.021 * * * \\
{[0.002]}\end{array}$ & & & $\begin{array}{c}0.016^{* * *} \\
{[0.003]}\end{array}$ & & & $\begin{array}{c}-0.006^{* * *} \\
{[0.002]}\end{array}$ \\
\hline $\begin{array}{l}\text { Crop Price Index * } \\
\text { Yr=1918 } \\
\text { County Controls? } \\
\text { Regulation Controls? } \\
\text { Bank Fixed Effects? } \\
\text { Year Fixed Effects? } \\
\text { Observations } \\
\text { R-squared }\end{array}$ & $\begin{array}{c}-0.048^{* * *} \\
{[0.006]} \\
\text { Yes } \\
\text { Yes } \\
\text { Yes } \\
\text { Yes } \\
57038 \\
0.419\end{array}$ & $\begin{array}{c}-0.047 * * * \\
{[0.006]} \\
\text { Yes } \\
\text { Yes } \\
\text { Yes } \\
\text { Yes } \\
57038 \\
0.420\end{array}$ & $\begin{array}{c}-0.040^{* * *} \\
{[0.007]} \\
\text { Yes } \\
\text { Yes } \\
\text { Yes } \\
\text { Yes } \\
57038 \\
0.425\end{array}$ & $\begin{array}{c}0.080 * * * \\
{[0.012]} \\
\text { Yes } \\
\text { Yes } \\
\text { Yes } \\
\text { Yes } \\
57038 \\
0.188\end{array}$ & $\begin{array}{c}0.080 * * * \\
{[0.012]} \\
\text { Yes } \\
\text { Yes } \\
\text { Yes } \\
\text { Yes } \\
57038 \\
0.189\end{array}$ & $\begin{array}{c}0.075^{* * *} \\
{[0.013]} \\
\text { Yes } \\
\text { Yes } \\
\text { Yes } \\
\text { Yes } \\
57038 \\
0.191\end{array}$ & $\begin{array}{c}0.104 * * * \\
{[0.015]} \\
\text { Yes } \\
\text { Yes } \\
\text { Yes } \\
\text { Yes } \\
57038 \\
0.202\end{array}$ & $\begin{array}{c}0.104 * * * \\
{[0.015]} \\
\text { Yes } \\
\text { Yes } \\
\text { Yes } \\
\text { Yes } \\
57038 \\
0.202\end{array}$ & $\begin{array}{c}0.112^{* * *} \\
{[0.013]} \\
\text { Yes } \\
\text { Yes } \\
\text { Yes } \\
\text { Yes } \\
57038 \\
0.231\end{array}$ \\
\hline \multicolumn{10}{|c|}{$\begin{array}{l}\text { Notes: The table presents the results of an OLS regression. The dependent variable is provided in the column heading. Each observation is a bank } \\
\text { and each bank is observed every two years. Only state-chartered financial institutions (i.e., commercial banks, trust companies, and savings banks) } \\
\text { are included in the regression. Only counties located in the Midwest, Great Plains, or South with consistent bank-level data published are included. } \\
\text { The sample also excludes locations with a city over } 25,001 \text { persons, fewer than } 250 \text { farms, or fewer than } 15,001 \text { improved farm acres. "Young } \\
\text { Bank" is an indicator variable for whether the bank was established in } 1914 \text { or later. County-level controls include the logarithms of county } \\
\text { population and manufacturing output per person, the fraction of county population living in a city or town of } 2,500 \text { or more persons, the fractions of } \\
\text { county population that are non-white, illiterate, or } 15 \text { years of age or younger, the number of national banks in the county, and the number of state } \\
\text { banks in the county. Regulation controls include the presence of Extended liability, deposit insurance, minimum capital above } \$ 10,001 \text {, and Fed } \\
\text { membership for state banks. Standard errors clustered by county are presented in parentheses below the coefficients. * denotes significance at } 10 \% \text {; } \\
* * \text { at } 5 \% \text { level and } * * * \text { at } 1 \% \text { levels. }\end{array}$} \\
\hline
\end{tabular}


Table 3: Effect of Crop Price Shock on National Bank Balance Sheets (1908-1920)

\begin{tabular}{|c|c|c|c|c|c|c|c|c|c|}
\hline \multirow[b]{2}{*}{ Crop Price Index } & \multicolumn{3}{|c|}{ Ln(Assets) } & \multicolumn{3}{|c|}{ Ln(Loans) } & \multicolumn{3}{|c|}{ Loans/Assets } \\
\hline & $\begin{array}{c}-0.052^{* * *} \\
{[0.018]}\end{array}$ & $\begin{array}{c}-0.049^{* * *} \\
{[0.018]}\end{array}$ & $\begin{array}{c}-0.198^{* * *} \\
{[0.060]}\end{array}$ & $\begin{array}{c}-0.033 \\
{[0.024]}\end{array}$ & $\begin{array}{l}-0.031 \\
{[0.024]}\end{array}$ & $\begin{array}{c}0.021 \\
{[0.074]}\end{array}$ & $\begin{array}{c}0.009 \\
{[0.008]}\end{array}$ & $\begin{array}{c}0.008 \\
{[0.008]}\end{array}$ & $\begin{array}{c}0.135^{* * *} \\
{[0.021]}\end{array}$ \\
\hline $\begin{array}{l}\text { Crop Price Index * } \\
\text { Young Bank }\end{array}$ & & $\begin{array}{l}-0.044 * \\
{[0.023]}\end{array}$ & $\begin{array}{c}-0.044 * * \\
{[0.022]}\end{array}$ & & $\begin{array}{l}-0.031 \\
{[0.028]}\end{array}$ & $\begin{array}{l}-0.033 \\
{[0.027]}\end{array}$ & & $\begin{array}{c}0.006 \\
{[0.008]}\end{array}$ & $\begin{array}{c}0.005 \\
{[0.008]}\end{array}$ \\
\hline $\begin{array}{l}\text { Fed Member * Crop } \\
\text { Price Index }\end{array}$ & & & $\begin{array}{l}0.156^{* *} \\
{[0.067]}\end{array}$ & & & $\begin{array}{c}-0.049 \\
{[0.083]}\end{array}$ & & & $\begin{array}{c}-0.130^{* * *} \\
{[0.023]}\end{array}$ \\
\hline $\begin{array}{l}\text { Extended Liability } * \\
\text { Crop Price Index }\end{array}$ & & & $\begin{array}{l}0.032^{*} \\
{[0.017]}\end{array}$ & & & $\begin{array}{c}0.002 \\
{[0.022]}\end{array}$ & & & $\begin{array}{c}-0.018^{* * *} \\
{[0.006]}\end{array}$ \\
\hline $\begin{array}{l}\text { Min Cap }>\$ 10,001 * \\
\text { Crop Price Index }\end{array}$ & & & $\begin{array}{c}-0.037 * * \\
{[0.015]}\end{array}$ & & & $\begin{array}{c}-0.066^{* * *} \\
{[0.020]}\end{array}$ & & & $\begin{array}{c}-0.016 * * * \\
{[0.006]}\end{array}$ \\
\hline $\begin{array}{l}\text { Deposit Insurance * } \\
\text { Crop Price Index }\end{array}$ & & & $\begin{array}{c}0.058^{* * *} \\
{[0.016]}\end{array}$ & & & $\begin{array}{c}0.075^{* * *} \\
{[0.021]}\end{array}$ & & & $\begin{array}{c}0.009 \\
{[0.006]}\end{array}$ \\
\hline $\begin{array}{l}\text { Crop Price Index * } \\
\text { Yr=1918 } \\
\text { County Controls? } \\
\text { Regulation Controls? } \\
\text { Bank Fixed Effects? } \\
\text { Year Fixed Effects? } \\
\text { Observations } \\
\text { R-squared }\end{array}$ & $\begin{array}{c}0.296^{* * *} \\
{[0.044]} \\
\text { Yes } \\
\text { Yes } \\
\text { Yes } \\
\text { Yes } \\
15450 \\
0.776\end{array}$ & $\begin{array}{c}0.300^{* * *} \\
{[0.044]} \\
\text { Yes } \\
\text { Yes } \\
\text { Yes } \\
\text { Yes } \\
15450 \\
0.776\end{array}$ & $\begin{array}{c}0.244 * * * \\
{[0.045]} \\
\text { Yes } \\
\text { Yes } \\
\text { Yes } \\
\text { Yes } \\
15450 \\
0.779\end{array}$ & $\begin{array}{c}0.167 * * * \\
{[0.056]} \\
\text { Yes } \\
\text { Yes } \\
\text { Yes } \\
\text { Yes } \\
15450 \\
0.706\end{array}$ & $\begin{array}{c}0.170^{* * *} \\
{[0.056]} \\
\text { Yes } \\
\text { Yes } \\
\text { Yes } \\
\text { Yes } \\
15450 \\
0.706\end{array}$ & $\begin{array}{c}0.179 * * * \\
{[0.057]} \\
\text { Yes } \\
\text { Yes } \\
\text { Yes } \\
\text { Yes } \\
15450 \\
0.711\end{array}$ & $\begin{array}{c}-0.067 * * * \\
{[0.017]} \\
\text { Yes } \\
\text { Yes } \\
\text { Yes } \\
\text { Yes } \\
15450 \\
0.139\end{array}$ & $\begin{array}{c}-0.067 * * * \\
{[0.017]} \\
\text { Yes } \\
\text { Yes } \\
\text { Yes } \\
\text { Yes } \\
15450 \\
0.139\end{array}$ & $\begin{array}{c}-0.026 \\
{[0.017]} \\
\text { Yes } \\
\text { Yes } \\
\text { Yes } \\
\text { Yes } \\
15450 \\
0.150\end{array}$ \\
\hline Crop Price Index & $\begin{array}{c}\text { (Capita } \\
0.010^{* * * *} \\
{[0.003]}\end{array}$ & $\begin{array}{c}\text { I+Surplus } \\
0.010^{* * *} \\
{[0.003]}\end{array}$ & $\begin{array}{c}/ \text { Assets } \\
0.003 \\
{[0.013]}\end{array}$ & $\begin{array}{c}\text { (Cash+Du } \\
-0.021^{* * *} \\
{[0.006]}\end{array}$ & $\begin{array}{c}\text { e from Ba } \\
-0.021 * * * \\
{[0.006]}\end{array}$ & $\begin{array}{c}-0.104^{* * *} \\
{[0.015]}\end{array}$ & $\begin{array}{c}\text { Bonds } \\
0.012^{*} \\
{[0.006]}\end{array}$ & $\begin{array}{c}\text { and Stocks } \\
0.012^{*} \\
{[0.006]}\end{array}$ & $\begin{array}{c}\text { Assets } \\
-0.028^{*} \\
{[0.015]}\end{array}$ \\
\hline $\begin{array}{l}\text { Crop Price Index * } \\
\text { Young Bank }\end{array}$ & & $\begin{array}{c}0.002 \\
{[0.005]}\end{array}$ & $\begin{array}{c}0.002 \\
{[0.005]}\end{array}$ & & $\begin{array}{l}-0.009 \\
{[0.008]}\end{array}$ & $\begin{array}{c}-0.009 \\
{[0.008]}\end{array}$ & & $\begin{array}{c}0.002 \\
{[0.006]}\end{array}$ & $\begin{array}{c}0.003 \\
{[0.006]}\end{array}$ \\
\hline $\begin{array}{l}\text { Fed Member * Crop } \\
\text { Price Index }\end{array}$ & & & $\begin{array}{c}0.013 \\
{[0.014]}\end{array}$ & & & $\begin{array}{c}0.090^{* * *} \\
{[0.018]}\end{array}$ & & & $\begin{array}{l}0.035^{* *} \\
{[0.017]}\end{array}$ \\
\hline $\begin{array}{l}\text { Extended Liability } * \\
\text { Crop Price Index }\end{array}$ & & & $\begin{array}{c}-0.004 \\
{[0.003]}\end{array}$ & & & $\begin{array}{c}0.006 \\
{[0.005]}\end{array}$ & & & $\begin{array}{c}0.014 * * * \\
{[0.005]}\end{array}$ \\
\hline $\begin{array}{l}\text { Min Cap }>\$ 10,001 * \\
\text { Crop Price Index }\end{array}$ & & & $\begin{array}{l}0.004^{*} \\
{[0.002]}\end{array}$ & & & $\begin{array}{c}0.006 \\
{[0.005]}\end{array}$ & & & $\begin{array}{l}0.009 * \\
{[0.005]}\end{array}$ \\
\hline $\begin{array}{l}\text { Deposit Insurance * } \\
\text { Crop Price Index }\end{array}$ & & & $\begin{array}{c}-0.010^{* * *} \\
{[0.003]}\end{array}$ & & & $\begin{array}{l}0.012 * * \\
{[0.005]}\end{array}$ & & & $\begin{array}{c}-0.022 * * * \\
{[0.005]}\end{array}$ \\
\hline $\begin{array}{l}\text { Crop Price Index * } \\
\text { Yr }=1918\end{array}$ & $\begin{array}{c}-0.065^{* * *} \\
{[0.007]}\end{array}$ & $\begin{array}{c}-0.065^{* * * *} \\
{[0.007]}\end{array}$ & $\begin{array}{c}-0.064 * * * \\
{[0.007]}\end{array}$ & $\begin{array}{c}0.115^{* * *} \\
{[0.013]}\end{array}$ & $\begin{array}{c}0.116^{* * *} \\
{[0.013]}\end{array}$ & $\begin{array}{c}0.084 * * * \\
{[0.014]}\end{array}$ & $\begin{array}{c}-0.054 * * * \\
{[0.014]}\end{array}$ & $\begin{array}{c}-0.054 * * * \\
{[0.014]}\end{array}$ & $\begin{array}{c}-0.062 * * * \\
{[0.014]}\end{array}$ \\
\hline County Controls? & Yes & Yes & Yes & Yes & Yes & Yes & Yes & Yes & Yes \\
\hline Regulation Controls? & Yes & Yes & Yes & Yes & Yes & Yes & Yes & Yes & Yes \\
\hline Bank $\mathrm{I}$ & Yes & Yes & Yes & Yes & Yes & Yes & Yes & Yes & Yes \\
\hline Year Fixed Effects? & Yes & Yes & Ye & Yes & Yes & Yes & Yes & Yes & Yes \\
\hline Observatio1 & 15450 & 15450 & & 15450 & 15450 & 15450 & 15450 & 15450 & 15450 \\
\hline R-squared & 0.499 & 0.499 & 0.503 & 0.194 & 0.194 & 0.198 & 0.136 & 0.136 & 0.148 \\
\hline
\end{tabular}

Notes: The table presents the results of an OLS regression. The dependent variable is provided in the column heading. Each observation is a bank and each bank is observed every two years. Only OCC-chartered financial institutions (i.e., national banks) are included in the regression. Only counties located in the Midwest, Great Plains, or South with consistent bank-level data published are included. The sample also excludes locations with a city over 25,001 persons, fewer than 250 farms, or fewer than 15,001 improved farm acres. "Young Bank" is an indicator variable for whether the bank was established in 1914 or later. County-level controls include the logarithms of county population and manufacturing output per person, the fraction of county population living in a city or town of 2,500 or more persons, the fractions of county population that are non-white, illiterate, or 15 years of age or younger, the number of national banks in the county, and the number of state banks in the county. Regulation controls include the presence of Extended liability, deposit insurance, for minimum capital above $\$ 10,001$ for state banks. Standard errors clustered by county are presented in parentheses below the coefficients. * denotes significance at $10 \% ; * *$ at $5 \%$ level and $* * *$ at $1 \%$ levels. 


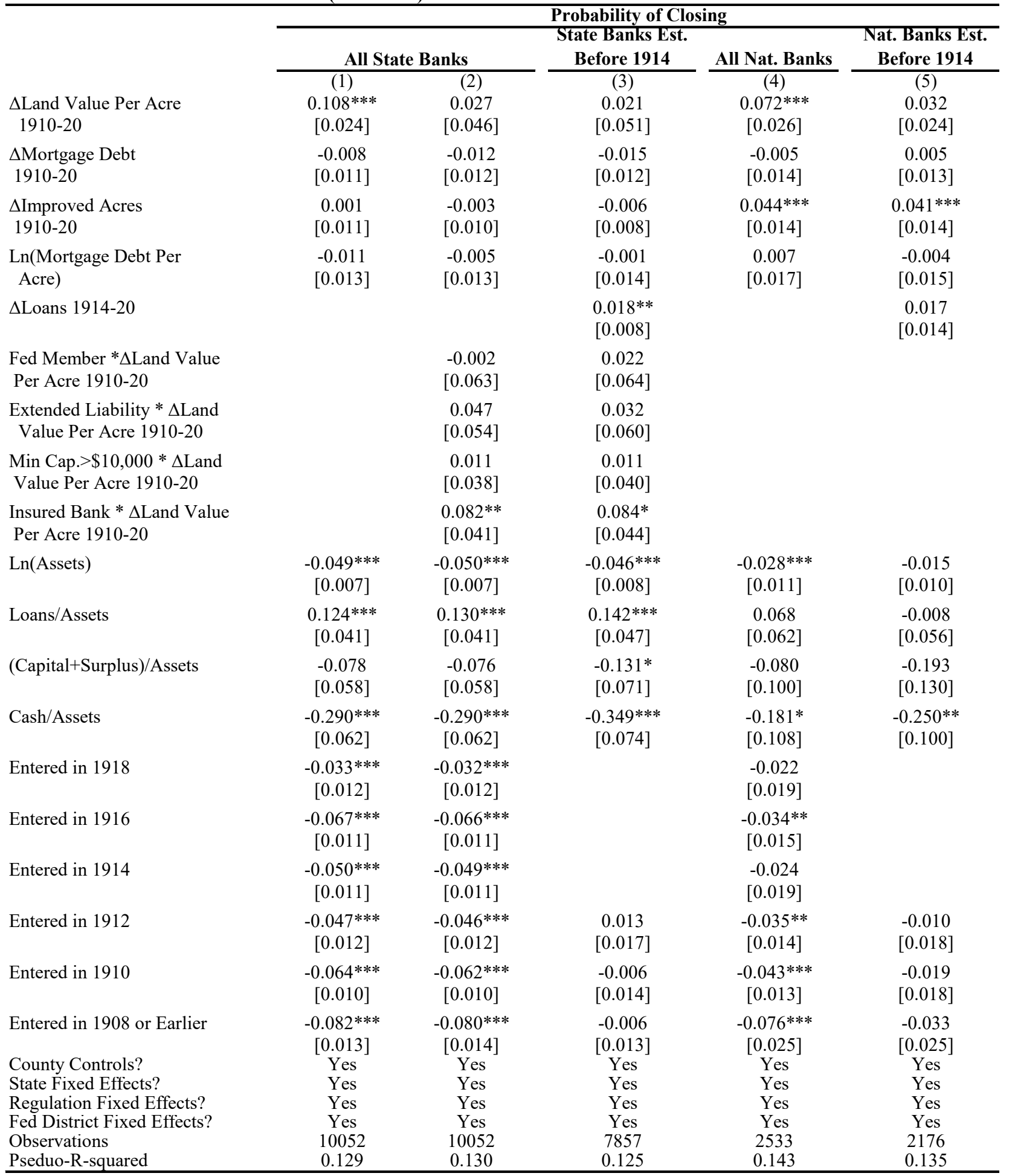

Notes: The table presents the marginal effects from a Probit regression. The dependent variable is an indicator variable for whether the bank closed before 1924. Each observation is a bank in 1920. The column headings denote which banks are included in the regressions. Only counties located in the Midwest, Great Plains, or South with consistent bank-level data published are included. The sample also excludes locations with a city over 25,000 persons, fewer than 250 farms, or fewer than 15,000 improved farm acres. County-level controls include the logarithms of county population and manufacturing output per person, the fraction of county population living in a city or town of 2,500 or more persons, the fractions of county population that are non-white, illiterate, or 15 years of age or younger, the number of national banks in the county, the number of state banks in the county, the logarithm of the county's size in square miles, average rainfall in the county, the standard deviation of rainfall in the county, distances to Mississippi River, Atlantic Ocean, Great Lakes, and Pacific Ocean, and a set of Fed district fixed effects. Because of state fixed effects, tegulation controls include deposit insurance and Fed membership for state banks. Robust standard errors clustered by county are presented in parentheses below the coefficients. * denotes significance at $10 \% ; * *$ at $5 \%$ level and $* * *$ at $1 \%$ levels. 
Table 5: Determinants of the Agricultural Bust (1920-25)

\begin{tabular}{|c|c|c|c|c|c|}
\hline \multirow[b]{2}{*}{$\Delta$ Crop Price Index 1919-25 } & \multicolumn{5}{|c|}{ Change in Ln(Farmland Value Per Acre) } \\
\hline & $\begin{array}{c}(1) \\
0.243^{* * *} \\
{[0.061]}\end{array}$ & $\begin{array}{c}(2) \\
0.289^{* * *} \\
{[0.056]}\end{array}$ & $\begin{array}{c}(3) \\
0.286^{* * *} \\
{[0.056]}\end{array}$ & $\begin{array}{c}(4) \\
0.284^{* * *} \\
{[0.056]}\end{array}$ & $\begin{array}{c}(5) \\
0.279^{* * *} \\
{[0.056]}\end{array}$ \\
\hline$\Delta$ Farmland Value $1910-20$ & $\begin{array}{c}-0.305^{* * *} \\
{[0.040]}\end{array}$ & $\begin{array}{c}-0.307^{* * *} \\
{[0.041]}\end{array}$ & $\begin{array}{c}-0.297 * * * \\
{[0.040]}\end{array}$ & $\begin{array}{c}-0.300^{* * *} \\
{[0.041]}\end{array}$ & $\begin{array}{c}-0.298^{* * *} \\
{[0.040]}\end{array}$ \\
\hline $\begin{array}{l}\text { Number of State Banks } \\
\text { in } 1920\end{array}$ & $\begin{array}{c}0.010 \\
{[0.008]}\end{array}$ & $\begin{array}{l}-0.001 \\
{[0.001]}\end{array}$ & $\begin{array}{c}0.001 \\
{[0.001]}\end{array}$ & $\begin{array}{l}-0.001 \\
{[0.001]}\end{array}$ & $\begin{array}{c}-0.001 \\
{[0.001]}\end{array}$ \\
\hline $\begin{array}{l}\text { Number of National Banks } \\
\text { in } 1920\end{array}$ & $\begin{array}{c}-0.019 \\
{[0.017]}\end{array}$ & $\begin{array}{c}-0.001 \\
{[0.003]}\end{array}$ & $\begin{array}{c}-0.001 \\
{[0.003]}\end{array}$ & $\begin{array}{c}-0.001 \\
{[0.003]}\end{array}$ & $\begin{array}{c}-0.001 \\
{[0.003]}\end{array}$ \\
\hline $\begin{array}{l}\text { State Banks in } 1920 * \Delta \text { Crop } \\
\text { Price Index 1919-25 }\end{array}$ & $\begin{array}{c}0.011 \\
{[0.008]}\end{array}$ & & & & \\
\hline $\begin{array}{l}\text { National Banks in } 1920 * \Delta \text { Crop } \\
\text { Price Index 1919-25 }\end{array}$ & $\begin{array}{c}-0.017 \\
{[0.015]}\end{array}$ & & & & \\
\hline $\begin{array}{l}\Delta \text { State Bank Loans } \\
1910-20\end{array}$ & & $\begin{array}{c}0.002 \\
{[0.003]}\end{array}$ & & & \\
\hline $\begin{array}{l}\Delta \text { National Bank Loans } \\
1910-20\end{array}$ & & $\begin{array}{l}-0.001 \\
{[0.001]}\end{array}$ & & & \\
\hline $\begin{array}{l}\text { Number of State Bank Closures } \\
\text { 1920-25 }\end{array}$ & & & $\begin{array}{c}-0.014 * * * \\
{[0.004]}\end{array}$ & & \\
\hline $\begin{array}{l}\text { Number of National Bank Closures } \\
1920-25\end{array}$ & & & $\begin{array}{c}0.005 \\
{[0.009]}\end{array}$ & & \\
\hline $\begin{array}{l}\text { Ln(Assets) of State Bank Closures } \\
\text { 1920-25 }\end{array}$ & & & & $\begin{array}{l}-0.002 * \\
{[0.001]}\end{array}$ & \\
\hline $\begin{array}{l}\text { Ln(Assets) of National Bank Closures } \\
1920-25\end{array}$ & & & & $\begin{array}{l}-0.001 \\
{[0.001]}\end{array}$ & \\
\hline $\begin{array}{l}\text { Fraction of Closed State Bank Assets } \\
\quad 1920-25\end{array}$ & & & & & $\begin{array}{c}-0.061 * * \\
{[0.030]}\end{array}$ \\
\hline $\begin{array}{l}\text { Fraction of Closed National Bank Assets } \\
\text { 1920-25 }\end{array}$ & & & & & $\begin{array}{c}-0.024 \\
{[0.027]}\end{array}$ \\
\hline County Controls? & Yes & Yes & Yes & Yes & Yes \\
\hline State Fixed Effects? & Yes & Yes & Yes & Yes & Yes \\
\hline Fed District Fixed Effects? & Yes & Yes & Yes & Yes & Yes \\
\hline Observations & 1247 & 1246 & 1247 & 1247 & 1247 \\
\hline R-squared & 0.627 & 0.626 & 0.629 & 0.626 & 0.627 \\
\hline
\end{tabular}

Notes: The table presents the results of an OLS regression. The dependent variable is the percentage change in farmland value per acre 1920-25. Each observation is a county. Only counties located in the Midwest, Great Plains, or South with consistent bank-level data published are included. The sample also excludes locations with a city over 25,000 , fewer than 250 farms, or fewer than 15,000 improved farming acres. County-level controls include the logarithms of county population and manufacturing output per person, the fraction of county population living in a city or town of 2,500 or more persons, the fractions of county population that are non-white, illiterate, or 15 years of age or younger, the number of national banks in the county, the number of state banks in the county, the logarithm of the county's size in square miles, average rainfall in the county, the standard deviation of rainfall in the county, distances to Mississippi River, Atlantic Ocean, Great Lakes, and Pacific Ocean, the percentage of unimproved land in the county, and a set of Fed district fixed effects. Robust standard errors are presented in parentheses below the coefficients. $*$ denotes significance at $10 \%$; ** at $5 \%$ level and $* * *$ at $1 \%$ levels. 
Table 6: Determinants of the Agricultural Bust - Instrumenting for State Bank Closures (1920-25)

\begin{tabular}{lccc}
\hline & \multicolumn{3}{c}{ Change in Ln(Farmland Value Per Acre) } \\
\cline { 2 - 4 }$\Delta$ Crop Price Index 1919-25 & $(1)$ & OLS - Reduced Form & IV \\
& $0.285^{* * *}$ & $(2)$ & $(3)$ ( \\
nFarmland Value 1910-20 & {$[0.056]$} & $0.286^{* * *}$ & $0.286^{* * *}$ \\
& $-0.296^{* * *}$ & {$[0.055]$} & {$[0.055]$} \\
Number of State Banks & {$[0.040]$} & $-0.291 * * *$ & $-0.289^{* * *}$ \\
in 1920 & 0.001 & {$[0.040]$} & {$[0.039]$} \\
Number of National Banks & {$[0.001]$} & 0.002 & 0.003 \\
in 1920 & 0.001 & {$[0.002]$} & {$[0.002]$} \\
Number of State Bank Closures & {$[0.003]$} & 0.001 & 0.001 \\
1920-25 & $-0.014^{* * *}$ & {$[0.003]$} & {$[0.003]$} \\
Sum of Predicted State Bank & {$[0.003]$} & & $-0.024^{* *}$ \\
Closure Prob. & & & {$[0.010]$} \\
& & $-0.019^{* *}$ & \\
Instrument Used? & & {$[0.008]$} & \\
County Controls? & None & None & Sum of Predicted State \\
State Fixed Effects? & Yes & Yes & Bank Closure Prob. \\
Fed District Fixed Effects? & Yes & Yes & Yes \\
Observations & Yes & Yes & Yes \\
R-squared & 1247 & 1247 & Yes \\
\hline
\end{tabular}

Notes: The table presents the results of an OLS regression. The dependent variable is the percentage change in farmland value per acre 1920-25. Each observation is a county. Only counties located in the Midwest, Great Plains, or South with consistent bank-level data published are included. The sample also excludes locations with a city over 25,000, fewer than 250 farms, or fewer than 15,000 improved farming acres. The "sum of Predicted State Bank Closure Probability" is obtained by summing the predicted probability of closure for each state bank from column (2) of Table 4. County-level controls include the logarithms of county population and manufacturing output per person, the fraction of county population living in a city or town of 2,500 or more persons, the fractions of county population that are non-white, illiterate, or 15 years of age or younger, the number of national banks in the county, the number of state banks in the county, the logarithm of the county's size in square miles, average rainfall in the county, the standard deviation of rainfall in the county, distances to Mississippi River, Atlantic Ocean, Great Lakes, and Pacific Ocean, the percentage of unimproved land in the county, and a set of Fed district fixed effects. Robust standard errors are presented in parentheses below the coefficients. ${ }^{*}$ denotes significance at $10 \% ; * *$ at $5 \%$ level and $* * *$ at $1 \%$ levels. 
Data Appendix for "Banking on the Boom, Tripped by the Bust: Banks and the World War I Agricultural Price Shock" 
Table A.1: Summary Statistics

County-Level

$\Delta$ Crop Price Index 1910-1919

$\Delta$ Crop Price Index 1919-1925

Biennial Rate of State Bank Entry (1908-1920)

Biennial Rate of National Bank Entry (1908-1920)

$\Delta$ Mortgage Debt 1910-1920 (Non-Logged)

$\Delta$ Improved Acres 1910-1920 (Non-Logged)

Mortgage Debt Per Acre in 1920

$\Delta$ Land Value Per Acre 1910-1920 (Non-Logged)

$\Delta$ Land Value Per Acre 1920-1925 (Non-Logged)

\# of State Banks in 1910

\# of National Banks in 1910

\# of State Banks in 1920

\# of National Banks in 1920

\# of State Banks Closed 1920-1924

\# of National Banks Closed 1920-1924

Bank-Level

Assets in 1920

Loans in 1920

Loans/Assets in 1920

(Capital+ Surplus)/ Assets in 1920

(Cash+ Due from Bank)/Assets in 1920

Bonds and Stocks/Assets in 1920

Fed Member Dummy in 1920 (State Banks Only) Insured Bank Dummy in 1920 (State Banks Only) $\Delta$ Assets 1914-1920 (Non-Logged)

$\Delta$ Loans 1914-1920 (Non-Logged)

$\Delta$ Loans/Assets 1914-1920

$\Delta$ (Capital+Surplus)/Assets 1914-1920

$\Delta($ Cash + Due from Bank $) /$ Assets 1914-1920

$\Delta$ (Bonds and Stocks)/Assets 1914-1920

$\%$ of State Banks Closed Between 1920-1924

$\%$ of National Banks Closed Between 1920-1924

Minimum State Bank Capital \$10,000 or Below

Extended Liability Requirement

Mean

Std Dev.

Min.

Max.

$\begin{array}{cccc}1.591 & 0.145 & 1.271 & 1.988 \\ -1.033 & 0.210 & -1.382 & -0.271 \\ 0.112 & 0.251 & 0.000 & 13.000 \\ 0.044 & 0.176 & 0.000 & 4.000 \\ 2.819 & 2.983 & -1.034 & 19.988 \\ 0.066 & 0.324 & -0.571 & 6.881 \\ 5.976 & 4.897 & 1.056 & 33.710 \\ 37.331 & 37.629 & -1.291 & 202.137 \\ -24.465 & 30.240 & -160.225 & 284.740 \\ 6.046 & 4.508 & 0.000 & 29.000 \\ 1.778 & 1.893 & 0.000 & 10.000 \\ 7.973 & 5.534 & 0.000 & 39.000 \\ 2.037 & 2.124 & 0.000 & 12.000 \\ 1.117 & 1.564 & 0.000 & 14.000 \\ 0.184 & 0.521 & 0.000 & 5.000\end{array}$

\begin{tabular}{cccc}
493,560 & 576,486 & 16,341 & $19,078,132$ \\
338,707 & 390,558 & 2,141 & $15,404,348$ \\
0.714 & 0.135 & 0.102 & 0.985 \\
0.157 & 0.077 & 0.024 & 0.832 \\
0.139 & 0.079 & 0.000 & 0.846 \\
0.090 & 0.103 & 0.000 & 0.733 \\
$5.3 \%$ & $22.5 \%$ & $0.0 \%$ & $100.0 \%$ \\
$28.5 \%$ & $45.1 \%$ & $0.0 \%$ & $100.0 \%$ \\
272,902 & 363,480 & $-1,691,953$ & $16,000,016$ \\
186,606 & 265,219 & $-321,952$ & $13,010,021$ \\
0.005 & 0.122 & -0.700 & 0.750 \\
-0.083 & 0.080 & -0.853 & 0.396 \\
-0.040 & 0.090 & -0.689 & 0.568 \\
0.034 & 0.081 & -0.351 & 0.733 \\
$9.8 \%$ & $29.7 \%$ & $0.0 \%$ & $100.0 \%$ \\
$1.3 \%$ & $11.4 \%$ & $0.0 \%$ & $100.0 \%$ \\
$39.2 \%$ & $48.8 \%$ & $0.0 \%$ & $100.0 \%$ \\
$81.3 \%$ & $39.0 \%$ & $0.0 \%$ & $100.0 \%$ \\
$31.3 \%$ & $46.4 \%$ & $0.0 \%$ & $100.0 \%$ \\
\hline
\end{tabular}

Notes: The table provides summary statistics for samples used in regressions. County-level data include all counties in the sample whether or not they had a bank. Bank-level data include all banks in the sample. 
Table A.2: Determinants of Bank Entry - Using Lagged Crop Price Change (1910-19:

\begin{tabular}{lccccc}
\hline & \multicolumn{3}{c}{ \# of New Banks In Period } \\
\cline { 2 - 3 } \cline { 5 - 6 } Change in Crop Price Index Over & $0.556^{* * *}$ & $0.661^{* * *}$ & & $-0.743^{* * *}$ & -0.122 \\
\cline { 2 - 3 } Previous Period & {$[0.092]$} & {$[0.119]$} & & {$[0.243]$} & {$[0.312]$} \\
Extended Liability * Crop Price & & 0.157 & & -0.095 \\
Index At Start of Period & & {$[0.121]$} & & {$[0.320]$} \\
Min Cap $>\$ 10,000 *$ Crop Price & & $-0.581^{* * *}$ & & $-1.151^{* * *}$ \\
Index At Start of Period & & {$[0.117]$} & & {$[0.303]$} \\
Deposit Insurance * Crop Price & & -0.045 & & $-0.970^{* *}$ \\
Index At Start of Period & & {$[0.141]$} & & {$[0.380]$} \\
County Controls? & Yes & Yes & & Yes & Yes \\
County Fixed Effects? & Yes & Yes & & Yes & Yes \\
Year Fixed Effects? & Yes & Yes & & Yes & Yes \\
Observations & 6536 & 6536 & & 2749 & 2749 \\
\hline
\end{tabular}

Notes: The table presents the results of a negative binomial model. The dependent variable is the number of new banks entering the county in each year. Each observation is a county and each county is observed every two years. Counties with no bank entry over the period are dropped from the sample. Only counties located in the Midwest, Great Plains, or South with consistent bank-level data published are included. The sample also excludes locations with cities over 25,000 population, fewer than 250 farms, or fewer than 15,000 improved farm acres. County-level controls include the logarithms of county population and manufacturing output per person, the fraction of county population living in a city or town of 2,500 or more persons, the fractions of county population that are nonwhite, illiterate, or 15 years of age or younger, the number of national banks in the county at the beginning of the period, and the number of state banks in the county at the beginning of the period. Robust standard errors clustered by county are presented in parentheses below the coefficients. ${ }^{*}$ denotes significance at $10 \%$; $* *$ at $5 \%$ level and $* * *$ at $1 \%$ levels. 
Table A.3: Determinants of Bank Entry - Cross-Section (1914-1920)

\# of New Banks In Period

Change in Crop Price Index

State Banks

National Banks

$1914-20$

$0.444 * * *$

$0.515^{*}$

County Controls?

[0.116]

[0.270]

State Fixed Effects?

Observations

Yes

Yes

Yes

Yes

1270

1270

Notes: The table presents the results of a negative binomial model. The dependent variable is the number of new banks entering the county in each year. Each

observation is a county and each county is observed every two years. Only counties located in the Midwest, Great Plains, or South with consistent bank-level data published are included. The sample also excludes locations with cities over 25,000 population, fewer than 250 farms, or fewer than 15,000 improved farm acres.

County-level controls include the logarithms of county population and manufacturing output per person, the fraction of county population living in a city or town of 2,500 or more persons, the fractions of county population that are nonwhite, illiterate, or 15 years of age or younger, the number of national banks in the county at the beginning of the period, the number of state banks in the county at the beginning of the period, and a set of Fed District fixed effects. Robust standard errors clustered by county are presented in parentheses below the coefficients. * denotes significance at $10 \% ; * *$ at $5 \%$ level and $* * *$ at $1 \%$ levels. 
Table A.4: Effect of Crop Price Shock on State Bank Entry Relative to National Bank Entry (1910-1920)

\begin{tabular}{lcc}
\hline & \multicolumn{2}{c}{ \# of New Banks In Period } \\
\cline { 2 - 3 } Crop Price Index At Start of & \multicolumn{2}{c}{ All Banks } \\
\cline { 2 - 3 } Period & $-0.596^{* * *}$ & $-0.598^{* * *}$ \\
Crop Price Index At Start of Period * & {$[0.131]$} & {$[0.151]$} \\
State Bank Dummy & $1.376^{* * *}$ & $1.577^{* * *}$ \\
Extended Liability * Crop Price & {$[0.033]$} & {$[0.067]$} \\
Index At Start of Period & & $1.296^{* * *}$ \\
Extended Liability * Crop Price & & {$[0.193]$} \\
Index At Start of Period * State Bank Dummy & & $-1.444^{* * *}$ \\
Min Cap>\$10,000 * Crop Price & & {$[0.191]$} \\
Index At Start of Period & & -0.174 \\
Min Cap>\$10,000 * Crop Price & & {$[0.187]$} \\
Index At Start of Period * State Bank Dummy & & $-0.374^{*}$ \\
Deposit Insurance* Crop Price & & {$[0.196]$} \\
Index At Start of Period & & 0.097 \\
Deposit Insurance * Crop Price & & {$[0.201]$} \\
Index At Start of Period * State Bank Dummy & & -0.318 \\
County Controls? & & {$[0.210]$} \\
County Fixed Effects? & & Yes \\
Regulation Controls? & & Yes \\
Year Fixed Effects? & Yes & Yes \\
Observations & Yes & Yes \\
Chi-Squared Test Statistic & Yes & 13,392 \\
\hline & 13,392 & $2047.84^{* * *}$ \\
\hline
\end{tabular}

Notes: The table presents the results of a negative binomial model. The dependent variable is the number of new banks entering the county in each year. The sample contains two observations per county: one for state bank entry and one for national bank entry. Each observation is a county and each county is observed every two years.

Counties with no bank entry over the period are dropped from the sample. Only counties located in the Midwest, Great Plains, or South with consistent bank-level data published are included. The sample also excludes locations with cities over 25,000 population, fewer than 250 farms, or fewer than 15,000 improved farm acres. County-level controls include the logarithms of county population and manufacturing output per person, the fraction of county population living in a city or town of 2,500 or more persons, the fractions of county population that are non-white, illiterate, or 15 years of age or younger, the number of national banks in the county at the beginning of the period, and the number of state banks in the county at the beginning of the period. Regulation controls include the presence of Extended liability, deposit insurance, or minimum capital above $\$ 10,000$ for state banks. The ChiSquared Test Statistic jointly measures whether the differential effect of state bank interactions are significantly different from zero. Robust standard errors clustered by county are presented in parentheses below the coefficients. ${ }^{*}$ denotes significance at $10 \% ; * *$ at $5 \%$ level and $* * *$ at $1 \%$ levels. 
Table A.5: Determinants of Bank Entry - Tobit Model (1910-1920)

\begin{tabular}{|c|c|c|c|c|}
\hline \multirow[b]{3}{*}{$\begin{array}{l}\text { Crop Price Index At Start of } \\
\text { Period }\end{array}$} & \multicolumn{4}{|c|}{ Rate of Banks Established } \\
\hline & \multicolumn{2}{|c|}{ State Banks } & \multicolumn{2}{|c|}{ National Banks } \\
\hline & $\begin{array}{c}0.266^{* * *} \\
{[0.050]}\end{array}$ & $\begin{array}{c}0.349^{* * *} \\
{[0.054]}\end{array}$ & $\begin{array}{c}-0.307 * * * \\
{[0.002]}\end{array}$ & $\begin{array}{c}-0.029^{* * *} \\
{[0.002]}\end{array}$ \\
\hline $\begin{array}{l}\text { Extended Liability * Crop Price } \\
\text { Index At Start of Period }\end{array}$ & & $\begin{array}{c}-0.038 \\
{[0.031]}\end{array}$ & & $\begin{array}{c}-0.183 * * * \\
{[0.003]}\end{array}$ \\
\hline $\begin{array}{l}\text { Min Cap }>\$ 10,000 * \text { Crop Price } \\
\text { Index At Start of Period }\end{array}$ & & $\begin{array}{c}-0.152 * * * \\
{[0.033]}\end{array}$ & & $\begin{array}{c}-0.193 * * * \\
{[0.002]}\end{array}$ \\
\hline $\begin{array}{l}\text { Deposit Insurance * Crop Price } \\
\text { Index At Start of Period }\end{array}$ & & $\begin{array}{c}-0.022 \\
{[0.032]}\end{array}$ & & $\begin{array}{c}-0.144 * * * \\
{[0.003]}\end{array}$ \\
\hline County Controls? & Yes & Yes & Yes & Yes \\
\hline County Fixed Effects? & Yes & Yes & Yes & Yes \\
\hline Regulation Controls? & Yes & Yes & Yes & Yes \\
\hline Year Fixed Effects? & Yes & Yes & Yes & Yes \\
\hline Observations & 7199 & 7199 & 7199 & 7199 \\
\hline
\end{tabular}

Notes: The table presents the results of an Tobit regression. The dependent variable is the rate of new banks entering the county in each year where the numerator is the number of entering banks and the denominator is the number of banks at the beginning of the period. Each observation is a county and each county is observed every two years. Only counties located in the Midwest, Great Plains, or South with consistent bank-level data published are included. The sample also excludes locations with cities over 25,000 population, fewer than 250 farms, or fewer than 15,000 improved farm acres. County-level controls include the logarithms of county population and manufacturing output per person, the fraction of county population living in a city or town of 2,500 or more persons, the fractions of county population that are non-white, illiterate, or 15 years of age or younger, the number of national banks in the county at the beginning of the period, and the number of state banks in the county at the beginning of the period. Regulation controls include the presence of Extended liability, deposit insurance, or minimum capital above $\$ 10,000$ for state banks. Robust standard errors clustered by county are presented in parentheses below the coefficients. ${ }^{*}$ denotes significance at $10 \% ; * *$ at $5 \%$ level 
Table A.6: Determinants of Bank Entry - Probit Model (1910-1920)

\begin{tabular}{lccccc}
\hline & \multicolumn{3}{c}{ Whether New Bank Created In Period } \\
\cline { 2 - 3 } \cline { 5 - 6 } Crop Price Index At Start of & $0.816^{* * *}$ & $1.130^{* * *}$ & & $-0.649^{* *}$ & -0.111 \\
Period & {$[0.161]$} & {$[0.179]$} & & {$[0.310]$} & {$[0.333]$} \\
Extended Liability * Crop Price & & -0.062 & & $-0.392^{*}$ \\
Index At Start of Period & & {$[0.113]$} & & {$[0.201]$} \\
Min Cap>\$10,000* Crop Price & & $-0.574^{* * *}$ & & $-0.328^{*}$ \\
Index At Start of Period & & {$[0.104]$} & & {$[0.177]$} \\
Deposit Insurance* Crop Price & & -0.082 & & -0.218 \\
Index At Start of Period & & {$[0.122]$} & & {$[0.218]$} \\
County Controls? & Yes & Yes & Yes & Yes \\
County Fixed Effects? & Yes & Yes & Yes & Yes \\
Regulation Controls? & Yes & Yes & Yes & Yes \\
Year Fixed Effects? & Yes & Yes & Yes & Yes \\
Observations & 7199 & 7199 & & 7199 & 7199 \\
\hline
\end{tabular}

Notes: The table presents the results of an probit regression. The dependent variable is a dummy variable for whether a bank entered the county during the specified period. Each observation is a county and each county is observed every two years. Only counties located in the Midwest, Great Plains, or South with consistent bank-level data published are included. The sample also excludes locations with cities over 25,000 population, fewer than 250 farms, or fewer than 15,000 improved farm acres. County-level controls include the logarithms of county population and manufacturing output per person, the fraction of county population living in a city or town of 2,500 or more persons, the fractions of county population that are non-white, illiterate, or 15 years of age or younger, the number of national banks in the county at the beginning of the period, and the number of state banks in the county at the beginning of the period. Regulation controls include the presence of Extended liability, deposit insurance, or minimum capital above $\$ 10,000$ for state banks. Robust standard errors clustered by county are presented in parentheses below the coefficients. * denotes significance at $10 \% ; * *$ at $5 \%$ level and $* * *$ at $1 \%$ levels. 
Table A.7: Effect of Crop Price Shock on Bank Balance Sheets - Cross-Section (1914-1920)

\begin{tabular}{|c|c|c|c|c|c|c|}
\hline \multirow[b]{2}{*}{$\Delta$ Crop Price Index 1914-19 } & \multicolumn{2}{|c|}{$\Delta$ Ln(Assets) } & \multicolumn{2}{|c|}{$\Delta$ Ln(Loans) } & \multicolumn{2}{|c|}{$\Delta$ Loans/Assets } \\
\hline & $\begin{array}{c}\text { State Banks } \\
0.140^{* * *} \\
{[0.039]}\end{array}$ & $\begin{array}{c}\text { National } \\
\text { Banks } \\
0.129^{* * *} \\
{[0.048]}\end{array}$ & $\begin{array}{c}\text { State Banks } \\
0.085^{* *} \\
{[0.042]}\end{array}$ & $\begin{array}{c}\text { National } \\
\text { Banks } \\
0.053 \\
{[0.056]}\end{array}$ & $\begin{array}{c}\text { State Banks } \\
-0.035^{* *} \\
{[0.015]}\end{array}$ & $\begin{array}{c}\text { National } \\
\text { Banks } \\
-0.043^{* * *} \\
{[0.016]}\end{array}$ \\
\hline County Controls? & Yes & Yes & Yes & Yes & Yes & Yes \\
\hline State Fixed Effects? & Yes & Yes & Yes & Yes & Yes & Yes \\
\hline Observations & 7316 & 2176 & 7316 & 2176 & 7316 & 2176 \\
\hline \multirow[t]{2}{*}{ R-squared } & 0.217 & 0.220 & 0.252 & 0.222 & 0.152 & 0.103 \\
\hline & \multicolumn{2}{|c|}{$\begin{array}{c}\Delta \text { (Capital+Surplus) } / \\
\text { Assets } \\
\end{array}$} & \multicolumn{2}{|c|}{$\begin{array}{c}\Delta(\text { Cash+Due from } \\
\text { Bank)/Assets } \\
\end{array}$} & \multicolumn{2}{|c|}{$\begin{array}{c}\Delta \text { Bonds and } \\
\text { Stocks/Assets }\end{array}$} \\
\hline$\Delta$ Crop Price Index 1914-19 & $\begin{array}{c}\text { State Banks } \\
-0.035^{* * *} \\
{[0.007]}\end{array}$ & $\begin{array}{c}\text { National } \\
\text { Banks } \\
-0.027^{* * *} \\
{[0.008]}\end{array}$ & $\begin{array}{c}\text { State Banks } \\
0.030^{* * *} \\
{[0.011]}\end{array}$ & $\begin{array}{c}\begin{array}{c}\text { National } \\
\text { Banks }\end{array} \\
0.048^{* * *} \\
{[0.013]}\end{array}$ & $\begin{array}{c}\text { State Banks } \\
0.005 \\
{[0.007]}\end{array}$ & $\begin{array}{c}\text { National } \\
\text { Banks } \\
-0.009 \\
{[0.014]}\end{array}$ \\
\hline County Controls? & Yes & Yes & Yes & Yes & Yes & Yes \\
\hline State Fixed Effects? & Yes & Yes & Yes & Yes & Yes & Yes \\
\hline Observations & 7316 & 2176 & 7316 & 2176 & 7316 & 2176 \\
\hline R-squared & 0.217 & 0.237 & 0.082 & 0.104 & 0.247 & 0.102 \\
\hline
\end{tabular}

Notes: The table presents the results of an OLS regression. The dependent variable is provided in the column heading. Each observation is the change in the balance sheet item from 1914 to 1920. Only state-chartered financial institutions (i.e., commercial banks, trust companies, and savings banks) are included in "State Banks" columns whereas only OCCchartered financial institutions (i.e., national banks) are included in the "National Banks" columns. Only counties located in the Midwest, Great Plains, or South with consistent bank-level data published are included. The sample also excludes locations with a city over 25,000 persons, fewer than 250 farms, or fewer than 15,000 improved farm acres. County-level controls include the logarithms of county population and manufacturing output per person, the fraction of county population living in a city or town of 2,500 or more persons, the fractions of county population that are non-white, illiterate, or 15 years of age or younger, the number of national banks in the county, the number of state banks in the county, and a set of Fed district fixed effects. Standard errors clustered by county are presented in parentheses below the coefficients. $*$ denotes significance at $10 \% ; *$ at $5 \%$ level and $* * *$ at $1 \%$ levels. 
Table A.8: Effect of Crop Price Shock on State Bank Balance Sheets - Using a First Order Autoregressive Model (1908-1920)

\begin{tabular}{|c|c|c|c|c|c|c|c|c|c|}
\hline \multirow[b]{2}{*}{ Crop Price Index } & \multicolumn{3}{|c|}{$\overline{\text { Ln(Assets) }}$} & \multicolumn{3}{|c|}{$\overline{\operatorname{Ln}(\text { Loans) }}$} & \multicolumn{3}{|c|}{ Loans/Assets } \\
\hline & $\begin{array}{c}0.177^{* * * *} \\
{[0.009]}\end{array}$ & $\begin{array}{c}0.177^{* * *} \\
{[0.009]}\end{array}$ & $\begin{array}{c}0.184^{* * *} \\
{[0.009]}\end{array}$ & $\begin{array}{c}0.172^{* * *} \\
{[0.010]}\end{array}$ & $\begin{array}{c}0.167^{* * *} \\
{[0.010]}\end{array}$ & $\begin{array}{c}0.156^{* * *} \\
{[0.011]}\end{array}$ & $\begin{array}{c}0.002 \\
{[0.004]}\end{array}$ & $\begin{array}{c}0.002 \\
{[0.004]}\end{array}$ & $\begin{array}{c}-0.010^{* *} \\
{[0.004]}\end{array}$ \\
\hline $\begin{array}{l}\text { Crop Price Index * } \\
\text { Young Bank }\end{array}$ & & $\begin{array}{c}0.007 \\
{[0.008]}\end{array}$ & $\begin{array}{c}0.009 \\
{[0.008]}\end{array}$ & & $\begin{array}{c}0.038^{* * *} \\
{[0.009]}\end{array}$ & $\begin{array}{c}0.036^{* * * *} \\
{[0.009]}\end{array}$ & & $\begin{array}{c}0.002 \\
{[0.004]}\end{array}$ & $\begin{array}{c}0.004 \\
{[0.004]}\end{array}$ \\
\hline $\begin{array}{l}\text { Fed Member * Crop } \\
\text { Price Index }\end{array}$ & & & $\begin{array}{l}-0.009 \\
{[0.018]}\end{array}$ & & & $\begin{array}{c}0.022 \\
{[0.021]}\end{array}$ & & & $\begin{array}{c}0.027 * * * \\
{[0.009]}\end{array}$ \\
\hline $\begin{array}{l}\text { Extended Liability * } \\
\text { Crop Price Index }\end{array}$ & & & $\begin{array}{l}0.010^{*} \\
{[0.006]}\end{array}$ & & & $\begin{array}{c}0.050 * * * \\
{[0.007]}\end{array}$ & & & $\begin{array}{c}0.019^{* * *} \\
{[0.003]}\end{array}$ \\
\hline $\begin{array}{l}\text { Min Cap }>\$ 10,000 * \\
\text { Crop Price Index }\end{array}$ & & & $\begin{array}{c}-0.040 * * * \\
{[0.006]}\end{array}$ & & & $\begin{array}{c}-0.058 * * * \\
{[0.007]}\end{array}$ & & & $\begin{array}{c}-0.007 * * * \\
{[0.003]}\end{array}$ \\
\hline $\begin{array}{l}\text { Insured Bank * } \\
\text { Crop Price Index }\end{array}$ & & & $\begin{array}{c}0.136 * * * \\
{[0.006]}\end{array}$ & & & $\begin{array}{c}0.138^{* * *} \\
{[0.007]}\end{array}$ & & & $\begin{array}{c}0.009^{* * *} \\
{[0.003]}\end{array}$ \\
\hline $\begin{array}{l}\text { Crop Price Index * } \\
\text { Yr=1918 } \\
\text { County Controls? } \\
\text { Bank Fixed Effects? } \\
\text { Regulation Controls? } \\
\text { Year Fixed Effects? } \\
\text { Observations }\end{array}$ & $\begin{array}{c}0.152 * * * \\
{[0.018]} \\
\text { Yes } \\
\text { Yes } \\
\text { Yes } \\
\text { Yes } \\
45331\end{array}$ & $\begin{array}{c}0.152^{* * *} \\
{[0.018]} \\
\text { Yes } \\
\text { Yes } \\
\text { Yes } \\
\text { Yes } \\
45331\end{array}$ & $\begin{array}{c}0.093 * * * \\
{[0.017]} \\
\text { Yes } \\
\text { Yes } \\
\text { Yes } \\
\text { Yes } \\
45331\end{array}$ & $\begin{array}{c}-0.163 * * * \\
{[0.020]} \\
\text { Yes } \\
\text { Yes } \\
\text { Yes } \\
\text { Yes } \\
45331\end{array}$ & $\begin{array}{c}-0.163 * * * \\
{[0.020]} \\
\text { Yes } \\
\text { Yes } \\
\text { Yes } \\
\text { Yes } \\
45331\end{array}$ & $\begin{array}{c}-0.229 * * * \\
{[0.020]} \\
\text { Yes } \\
\text { Yes } \\
\text { Yes } \\
\text { Yes } \\
45331\end{array}$ & $\begin{array}{c}-0.203 * * * \\
{[0.008]} \\
\text { Yes } \\
\text { Yes } \\
\text { Yes } \\
\text { Yes } \\
45331\end{array}$ & $\begin{array}{c}-0.203 * * * \\
{[0.008]} \\
\text { Yes } \\
\text { Yes } \\
\text { Yes } \\
\text { Yes } \\
45331\end{array}$ & $\begin{array}{c}-0.208 * * * \\
{[0.008]} \\
\text { Yes } \\
\text { Yes } \\
\text { Yes } \\
\text { Yes } \\
45331\end{array}$ \\
\hline Crop Price Index & $\begin{array}{c}\text { (Capi } \\
-0.018^{* * * *} \\
{[0.002]}\end{array}$ & $\begin{array}{c}\text { al+Surplus) } \\
-0.018^{* * * *} \\
{[0.002]}\end{array}$ & $\begin{array}{c}\text { ssets } \\
-0.018^{* * *} \\
{[0.002]}\end{array}$ & $\begin{array}{c}\text { Cash+1 } \\
0.023^{* * *} \\
{[0.003]}\end{array}$ & $\begin{array}{c}\text { e from Ba } \\
0.023^{* * *} \\
{[0.003]}\end{array}$ & $\begin{array}{c}/ \text { Assets } \\
0.036^{* * * *} \\
{[0.004]}\end{array}$ & $\begin{array}{c}\text { Bond } \\
-0.027^{* * * *} \\
{[0.002]}\end{array}$ & $\begin{array}{c}\text { and Stocks } \\
-0.027^{* * * *} \\
{[0.002]}\end{array}$ & $\begin{array}{c}\text { ssets } \\
-0.006^{* *} \\
{[0.002]}\end{array}$ \\
\hline $\begin{array}{l}\text { Crop Price Index * } \\
\text { Young Bank }\end{array}$ & & $\begin{array}{c}-0.000 \\
{[0.002]}\end{array}$ & $\begin{array}{c}-0.001 \\
{[0.002]}\end{array}$ & & $\begin{array}{c}0.002 \\
{[0.003]}\end{array}$ & $\begin{array}{c}0.002 \\
{[0.003]}\end{array}$ & & $\begin{array}{c}0.002 \\
{[0.002]}\end{array}$ & $\begin{array}{c}0.003 \\
{[0.002]}\end{array}$ \\
\hline $\begin{array}{l}\text { Fed Member * Crop } \\
\text { Price Index }\end{array}$ & & & $\begin{array}{c}0.003 \\
{[0.004]}\end{array}$ & & & $\begin{array}{c}-0.020 * * * \\
{[0.008]}\end{array}$ & & & $\begin{array}{l}0.010^{* *} \\
{[0.004]}\end{array}$ \\
\hline $\begin{array}{l}\text { Extended Liability * } \\
\text { Crop Price Index }\end{array}$ & & & $\begin{array}{c}0.004 * * * \\
{[0.001]}\end{array}$ & & & $\begin{array}{c}-0.017 * * * \\
{[0.002]}\end{array}$ & & & $\begin{array}{c}-0.016^{* * *} \\
{[0.001]}\end{array}$ \\
\hline $\begin{array}{l}\text { Min Cap }>\$ 10,000 * \\
\text { Crop Price Index }\end{array}$ & & & $\begin{array}{l}-0.001 \\
{[0.001]}\end{array}$ & & & $\begin{array}{l}-0.004 * \\
{[0.002]}\end{array}$ & & & $\begin{array}{c}-0.024 * * * \\
{[0.001]}\end{array}$ \\
\hline $\begin{array}{l}\text { Insured Bank* } \\
\text { Crop Price Index }\end{array}$ & & & $\begin{array}{c}-0.023 * * * \\
{[0.001]}\end{array}$ & & & $\begin{array}{l}0.005^{* *} \\
{[0.002]}\end{array}$ & & & $\begin{array}{l}0.003^{*} \\
{[0.002]}\end{array}$ \\
\hline $\begin{array}{l}\text { Crop Price Index * } \\
\text { Yr }=1918\end{array}$ & $\begin{array}{c}-0.052 * * * \\
{[0.004]}\end{array}$ & $\begin{array}{c}-0.052 * * * \\
{[0.004]}\end{array}$ & $\begin{array}{c}-0.045 * * * \\
{[0.004]}\end{array}$ & $\begin{array}{c}0.060 * * * \\
{[0.007]}\end{array}$ & $\begin{array}{c}0.060 * * * \\
{[0.007]}\end{array}$ & $\begin{array}{c}0.059 * * * \\
{[0.007]}\end{array}$ & $\begin{array}{c}0.084 * * * \\
{[0.004]}\end{array}$ & $\begin{array}{c}0.084 * * * \\
{[0.004]}\end{array}$ & $\begin{array}{c}0.083 * * * \\
{[0.004]}\end{array}$ \\
\hline County Controls? & Yes & Yes & Yes & Yes & Yes & Yes & Yes & Yes & Yes \\
\hline Bank Fixed Effects? & Yes & Yes & Yes & Yes & Yes & Yes & Yes & Yes & Yes \\
\hline Regulation Controls? & Yes & Yes & Yes & Yes & Yes & Yes & Yes & Yes & Yes \\
\hline Year Fixed Effects? & Yes & Yes & Yes & Yes & Yes & Yes & Yes & Yes & Yes \\
\hline Observations & 45331 & 45331 & 45331 & 45331 & 45331 & 45331 & 45331 & 45331 & 45331 \\
\hline
\end{tabular}

Notes: The table presents the results of a first-order autoregressive OLS regression. The dependent variable is provided in the column heading. Each observation is a bank and each bank is observed every two years. Only state-chartered financial institutions (i.e., commercial banks, trust companies, and savings banks) are included in the regression. Only counties located in the Midwest, Great Plains, or South with consistent bank-level data published are included. The sample also excludes locations with a city over 25,000 persons, fewer than 250 farms, or fewer than 15,000 improved farm acres. "Young Bank" is an indicator variable for whether the bank was established in 1914 or later. County-level controls include the logarithms of county population and manufacturing output per person, the fraction of county population living in a city or town of 2,500 or more persons, the fractions of county population that are non-white, illiterate, or 15 years of age or younger, the number of national banks in the county, and the number of state banks in the county. Regulation controls include the presence of Extended liability, deposit insurance, minimum capital above $\$ 10,001$, and Fed membership for state banks. Standard errors clustered by county are presented in parentheses below the coefficients. * denotes significance at $10 \%$; ** at $5 \%$ level and $* * *$ at $1 \%$ levels. 
Table A.9: Effect of Crop Price Shock on National Bank Balance Sheets - Using a First Order Autoregressive Model (1908-1920)

\begin{tabular}{|c|c|c|c|c|c|c|c|c|c|}
\hline \multirow[b]{2}{*}{ Crop Price Index } & \multicolumn{3}{|c|}{ Ln(Assets) } & \multicolumn{3}{|c|}{ Ln(Loans) } & \multicolumn{3}{|c|}{ Loans/Assets } \\
\hline & $\begin{array}{c}-0.009 \\
{[0.013]}\end{array}$ & $\begin{array}{l}-0.008 \\
{[0.013]}\end{array}$ & $\begin{array}{l}-0.100^{* *} \\
{[0.042]}\end{array}$ & $\begin{array}{c}-0.002 \\
{[0.015]}\end{array}$ & $\begin{array}{c}-0.002 \\
{[0.015]}\end{array}$ & $\begin{array}{c}0.045 \\
{[0.050]}\end{array}$ & $\begin{array}{c}0.001 \\
{[0.006]}\end{array}$ & $\begin{array}{c}0.001 \\
{[0.006]}\end{array}$ & $\begin{array}{c}0.114^{* * * *} \\
{[0.019]}\end{array}$ \\
\hline $\begin{array}{l}\text { Crop Price Index * } \\
\text { Young Bank }\end{array}$ & & $\begin{array}{c}-0.043 * * * \\
{[0.014]}\end{array}$ & $\begin{array}{c}-0.037 * * * \\
{[0.014]}\end{array}$ & & $\begin{array}{c}-0.020 \\
{[0.017]}\end{array}$ & $\begin{array}{c}-0.014 \\
{[0.016]}\end{array}$ & & $\begin{array}{l}0.018^{* *} \\
{[0.008]}\end{array}$ & $\begin{array}{l}0.018 * * \\
{[0.008]}\end{array}$ \\
\hline $\begin{array}{l}\text { Fed Member * Crop } \\
\text { Price Index }\end{array}$ & & & $\begin{array}{l}0.080^{*} \\
{[0.044]}\end{array}$ & & & $\begin{array}{c}-0.053 \\
{[0.053]}\end{array}$ & & & $\begin{array}{c}-0.113 * * * \\
{[0.021]}\end{array}$ \\
\hline $\begin{array}{l}\text { Extended Liability* } \\
\text { Crop Price Index }\end{array}$ & & & $\begin{array}{c}0.002 \\
{[0.009]}\end{array}$ & & & $\begin{array}{l}-0.008 \\
{[0.011]}\end{array}$ & & & $\begin{array}{l}-0.008^{*} \\
{[0.004]}\end{array}$ \\
\hline $\begin{array}{l}\text { Min Cap }>\$ 10,000 * \\
\text { Crop Price Index }\end{array}$ & & & $\begin{array}{l}0.022^{* *} \\
{[0.009]}\end{array}$ & & & $\begin{array}{l}-0.005 \\
{[0.010]}\end{array}$ & & & $\begin{array}{c}-0.018^{* * *} \\
{[0.004]}\end{array}$ \\
\hline $\begin{array}{l}\text { Deposit Insurance * } \\
\text { Crop Price Index }\end{array}$ & & & $\begin{array}{c}0.127 * * * \\
{[0.010]}\end{array}$ & & & $\begin{array}{c}0.130^{* * *} \\
{[0.012]}\end{array}$ & & & $\begin{array}{c}0.003 \\
{[0.005]}\end{array}$ \\
\hline $\begin{array}{l}\text { Crop Price Index * } \\
\text { Yr }=1918\end{array}$ & $\begin{array}{c}0.197 * * * \\
{[0.026]}\end{array}$ & $\begin{array}{c}0.201 * * * \\
{[0.026]}\end{array}$ & $\begin{array}{c}0.134 * * * \\
{[0.027]}\end{array}$ & $\begin{array}{c}0.106^{* * *} \\
{[0.030]}\end{array}$ & $\begin{array}{c}0.109 * * * \\
{[0.030]}\end{array}$ & $\begin{array}{l}0.067 * * \\
{[0.032]}\end{array}$ & $\begin{array}{c}-0.048 * * * \\
{[0.012]}\end{array}$ & $\begin{array}{c}-0.051 * * * \\
{[0.012]}\end{array}$ & $\begin{array}{l}-0.024 * \\
{[0.013]}\end{array}$ \\
\hline County Controls? & Yes & Yes & Yes & Yes & Yes & Yes & Yes & Yes & Yes \\
\hline Bank Fixed Effects? & Yes & Yes & Yes & Yes & Yes & Yes & Yes & Yes & Yes \\
\hline Regulation Controls? & Yes & Yes & Yes & Yes & Yes & Yes & Yes & Yes & Yes \\
\hline Year Fixed Effects? & Yes & Yes & Yes & Yes & Yes & Yes & Yes & Yes & Yes \\
\hline Observations & 12516 & 12516 & 12516 & 12516 & 12516 & 12516 & 12516 & 12516 & 12516 \\
\hline Crop Price Index & $\begin{array}{c}\text { (Capi } \\
0.008^{* * *} \\
{[0.002]}\end{array}$ & 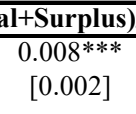 & $\begin{array}{c}\text { Assets } \\
0.003 \\
{[0.008]}\end{array}$ & $\begin{array}{c}\text { (Cash+1 } \\
-0.012^{* *} \\
{[0.005]}\end{array}$ & $\begin{array}{c}\text { e from Ba } \\
-0.011 * * \\
{[0.005]}\end{array}$ & $\begin{array}{c}\text { /Assets } \\
-0.095^{* * *} \\
{[0.017]}\end{array}$ & $\begin{array}{c}\text { Bond } \\
0.001 \\
{[0.004]}\end{array}$ & $\begin{array}{c}\text { and Stocks } \\
0.001 \\
{[0.004]}\end{array}$ & $\begin{array}{c}\text { sssets } \\
-0.042 * * * \\
{[0.014]}\end{array}$ \\
\hline $\begin{array}{l}\text { Crop Price Index * } \\
\text { Young Bank }\end{array}$ & & $\begin{array}{c}-0.007 * * \\
{[0.003]}\end{array}$ & $\begin{array}{c}-0.008^{* * *} \\
{[0.003]}\end{array}$ & & $\begin{array}{c}-0.011 \\
{[0.007]}\end{array}$ & $\begin{array}{l}-0.011 \\
{[0.007]}\end{array}$ & & $\begin{array}{c}-0.004 \\
{[0.005]}\end{array}$ & $\begin{array}{l}-0.005 \\
{[0.005]}\end{array}$ \\
\hline $\begin{array}{l}\text { Fed Member * Crop } \\
\text { Price Index }\end{array}$ & & & $\begin{array}{c}0.010 \\
{[0.008]}\end{array}$ & & & $\begin{array}{c}0.087^{* * * *} \\
{[0.019]}\end{array}$ & & & $\begin{array}{c}0.041^{* * *} \\
{[0.015]}\end{array}$ \\
\hline $\begin{array}{l}\text { Extended Liability* } \\
\text { Crop Price Index }\end{array}$ & & & $\begin{array}{c}-0.005 * * * \\
{[0.002]}\end{array}$ & & & $\begin{array}{c}0.005 \\
{[0.004]}\end{array}$ & & & $\begin{array}{l}0.005^{*} \\
{[0.003]}\end{array}$ \\
\hline $\begin{array}{l}\text { Min Cap }>\$ 10,000 * \\
\text { Crop Price Index }\end{array}$ & & & $\begin{array}{c}0.000 \\
{[0.002]}\end{array}$ & & & $\begin{array}{l}0.006^{*} \\
{[0.003]}\end{array}$ & & & $\begin{array}{c}0.008 * * * \\
{[0.003]}\end{array}$ \\
\hline $\begin{array}{l}\text { Deposit Insurance * } \\
\text { Crop Price Index }\end{array}$ & & & $\begin{array}{c}-0.011 * * * \\
{[0.002]}\end{array}$ & & & $\begin{array}{c}0.010^{* * *} \\
{[0.004]}\end{array}$ & & & $\begin{array}{c}-0.013 * * * \\
{[0.003]}\end{array}$ \\
\hline $\begin{array}{l}\text { Crop Price Index * } \\
\text { Yr }=1918\end{array}$ & $\begin{array}{c}-0.051 * * * \\
{[0.005]}\end{array}$ & $\begin{array}{c}-0.050 * * * \\
{[0.005]}\end{array}$ & $\begin{array}{c}-0.047 * * * \\
{[0.005]}\end{array}$ & $\begin{array}{c}0.081 * * * \\
{[0.010]}\end{array}$ & $\begin{array}{c}0.082 * * * \\
{[0.010]}\end{array}$ & $\begin{array}{c}0.059 * * * \\
{[0.011]}\end{array}$ & $\begin{array}{c}-0.013 \\
{[0.008]}\end{array}$ & $\begin{array}{c}-0.013 \\
{[0.008]}\end{array}$ & $\begin{array}{c}-0.018^{* *} \\
{[0.009]}\end{array}$ \\
\hline County Controls? & Yes & Yes & Yes & Yes & Yes & Yes & Yes & Yes & Yes \\
\hline Bank Fixed Effects? & Yes & Yes & Yes & Yes & Yes & Yes & Yes & Yes & Yes \\
\hline Regulation Controls? & Yes & Yes & Yes & Yes & Yes & Yes & Yes & Yes & Yes \\
\hline Year Fixed Effects? & Yes & Yes & Yes & Yes & Yes & Yes & Yes & Yes & Yes \\
\hline Observations & 12516 & 12516 & 12516 & 12516 & 12516 & 12516 & 12516 & 12516 & 12516 \\
\hline
\end{tabular}

Notes: The table presents the results of a first-order autoregressive OLS regression. The dependent variable is provided in the column heading. Each observation is a bank and each bank is observed every two years. Only OCC-chartered financial institutions (i.e., national banks) are included in the regression. Only counties located in the Midwest, Great Plains, or South with consistent bank-level data published are included. The sample also excludes locations with a city over 25,000 persons, fewer than 250 farms, or fewer than 15,000 improved farm acres. "Young Bank" is an indicator variable for whether the bank was established in 1914 or later. County-level controls include the logarithms of county population and manufacturing output per person, the fraction of county population living in a city or town of 2,500 or more persons, the fractions of county population that are nonwhite, illiterate, or 15 years of age or younger, the number of national banks in the county, and the number of state banks in the county. Regulation controls include the presence of Extended liability, deposit insurance, and minimum capital above $\$ 10,001$ for state banks. Standard errors clustered by county are presented in parentheses below the coefficients. * denotes significance at $10 \%$; ** at $5 \%$ level and $* * *$ at $1 \%$ levels. 
Table A.10: Effect of Crop Price Shock on Bank Balance Sheet Ratios - Including Lagged Assets (1908-1920)

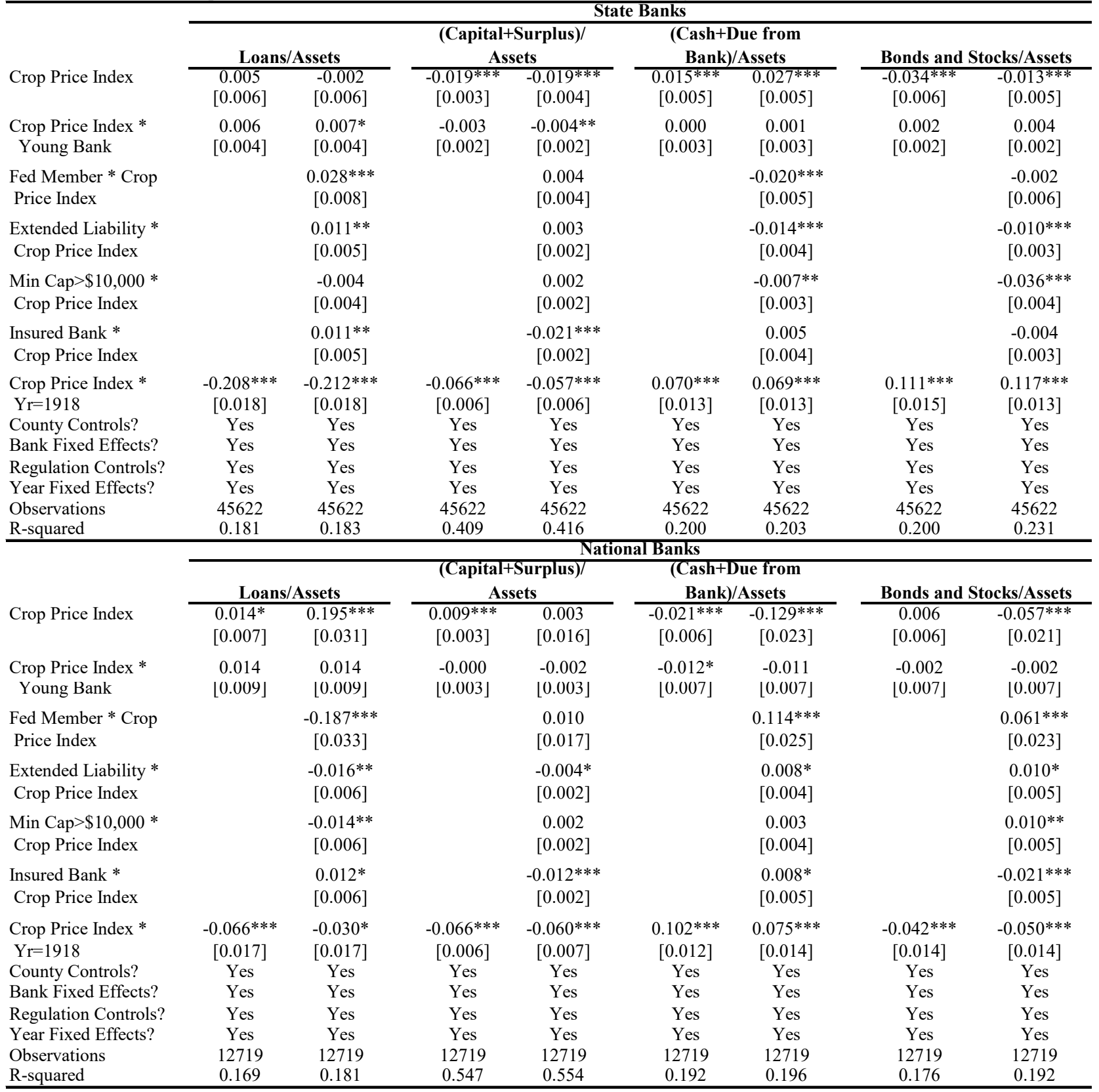

Notes: The table presents the results of an OLS regression. The dependent variable is provided in the column heading. Each observation is a bank and each bank is observed every two years. Only state-chartered financial institutions (i.e., commercial banks, trust companies, and savings banks) are included in the top panel whereas OCC-chartered financial institutions (i.e., national banks) are included in the bottom panel. All regressions contain the lagged value of the logarthm of Assets. Only counties located in the Midwest, Great Plains, or South with consistent bank-level data published are included. The sample also excludes locations with a city over 25,000 persons, fewer than 250 farms, or fewer than 15,000 improved farm acres. "Young Bank" is an indicator variable for whether the bank was established in 1914 or later. County-level controls include the logarithms of county population and manufacturing output per person, the fraction of county population living in a city or town of 2,500 or more persons, the fractions of county population that are non-white, illiterate, or 15 years of age or younger, the number of national banks in the county, and the number of state banks in the county. Regulation controls include the presence of Extended liability, deposit insurance, minimum capital above $\$ 10,001$, and Fed membership for state banks. Standard errors clustered by county are presented in parentheses below the coefficients. * denotes significance at $10 \% ; *$ at $5 \%$ level and $* * *$ at $1 \%$ levels. 
Table A.11: Effect of Crop Price Shock on State Bank Balance Sheets Relative to National Banks (1908-1920)

\begin{tabular}{|c|c|c|c|c|c|c|}
\hline \multirow[b]{2}{*}{ Crop Price Index } & \multicolumn{2}{|c|}{ Ln(Assets) } & \multicolumn{2}{|c|}{ Ln(Loans) } & \multicolumn{2}{|c|}{ Loans/Assets } \\
\hline & $\begin{array}{c}0.055^{* * *} \\
{[0.017]}\end{array}$ & $\begin{array}{c}0.129 * * * \\
{[0.048]}\end{array}$ & $\begin{array}{c}0.069 * * * \\
{[0.020]}\end{array}$ & $\begin{array}{c}0.299^{* * *} \\
{[0.057]}\end{array}$ & $\begin{array}{l}0.011^{*} \\
{[0.006]}\end{array}$ & $\begin{array}{c}0.107^{* * *} \\
{[0.016]}\end{array}$ \\
\hline $\begin{array}{l}\text { Crop Price Index * } \\
\text { State Bank }\end{array}$ & $\begin{array}{c}0.139 * * * \\
{[0.006]}\end{array}$ & $\begin{array}{c}0.044 \\
{[0.049]}\end{array}$ & $\begin{array}{c}0.128 * * * \\
{[0.008]}\end{array}$ & $\begin{array}{c}-0.136 * * \\
{[0.056]}\end{array}$ & $\begin{array}{c}-0.010 * * * \\
{[0.002]}\end{array}$ & $\begin{array}{c}-0.116^{* * *} \\
{[0.016]}\end{array}$ \\
\hline Young Bank & & $\begin{array}{c}-0.000^{* * *} \\
{[0.000]}\end{array}$ & & $\begin{array}{c}-0.000^{* * *} \\
{[0.000]}\end{array}$ & & $\begin{array}{c}-0.000^{* * *} \\
{[0.000]}\end{array}$ \\
\hline Young Bank * State Bank & & $\begin{array}{c}0.000^{* * *} \\
{[0.000]}\end{array}$ & & $\begin{array}{c}0.000^{* * *} \\
{[0.000]}\end{array}$ & & $\begin{array}{c}-0.000 \\
{[0.000]}\end{array}$ \\
\hline $\begin{array}{l}\text { Young Bank * Crop } \\
\text { Price Index }\end{array}$ & & $\begin{array}{c}-0.074 * * * \\
{[0.019]}\end{array}$ & & $\begin{array}{c}-0.119^{* * *} \\
{[0.025]}\end{array}$ & & $\begin{array}{c}-0.022 * * * \\
{[0.007]}\end{array}$ \\
\hline $\begin{array}{l}\text { Young Bank * Crop } \\
\text { Price Index * State Bank }\end{array}$ & & $\begin{array}{l}0.049^{* *} \\
{[0.021]}\end{array}$ & & $\begin{array}{c}0.073 * * * \\
{[0.027]}\end{array}$ & & $\begin{array}{c}0.013 \\
{[0.008]}\end{array}$ \\
\hline $\begin{array}{l}\text { Fed Member * Crop } \\
\text { Price Index }\end{array}$ & & $\begin{array}{l}-0.052 \\
{[0.048]}\end{array}$ & & $\begin{array}{c}-0.181 * * * \\
{[0.055]}\end{array}$ & & $\begin{array}{c}-0.078 * * * \\
{[0.015]}\end{array}$ \\
\hline $\begin{array}{l}\text { Fed Member * Crop } \\
\text { Price Index } * \text { State Bank }\end{array}$ & & $\begin{array}{c}0.014 \\
{[0.054]}\end{array}$ & & $\begin{array}{c}0.177 * * * \\
{[0.064]}\end{array}$ & & $\begin{array}{l}0.106^{* * *} \\
{[0.018]}\end{array}$ \\
\hline $\begin{array}{l}\text { Extended Liability * } \\
\text { Crop Price Index }\end{array}$ & & $\begin{array}{l}0.037^{* *} \\
{[0.018]}\end{array}$ & & $\begin{array}{c}0.017 \\
{[0.024]}\end{array}$ & & $\begin{array}{c}-0.013 * * \\
{[0.007]}\end{array}$ \\
\hline $\begin{array}{l}\text { Extended Liability } * \\
\text { Crop Price Index * State Bank }\end{array}$ & & $\begin{array}{c}0.021 \\
{[0.020]}\end{array}$ & & $\begin{array}{c}0.066^{* * *} \\
{[0.025]}\end{array}$ & & $\begin{array}{c}0.025^{* * *} \\
{[0.007]}\end{array}$ \\
\hline $\begin{array}{l}\text { Min Cap }>\$ 10,001 * \\
\text { Crop Price Index }\end{array}$ & & $\begin{array}{c}-0.034 * * \\
{[0.017]}\end{array}$ & & $\begin{array}{c}-0.063 * * * \\
{[0.022]}\end{array}$ & & $\begin{array}{c}-0.014 * * \\
{[0.006]}\end{array}$ \\
\hline $\begin{array}{l}\text { Min Cap }>\$ 10,001 * \\
\text { Crop Price Index * State Bank }\end{array}$ & & $\begin{array}{c}-0.089 * * * \\
{[0.019]}\end{array}$ & & $\begin{array}{c}-0.096^{* * *} \\
{[0.023]}\end{array}$ & & $\begin{array}{c}0.000 \\
{[0.007]}\end{array}$ \\
\hline $\begin{array}{l}\text { Deposit Insurance * } \\
\text { Crop Price Index }\end{array}$ & & $\begin{array}{c}0.066^{* * *} \\
{[0.018]}\end{array}$ & & $\begin{array}{c}0.088 * * * \\
{[0.023]}\end{array}$ & & $\begin{array}{l}0.013^{*} \\
{[0.007]}\end{array}$ \\
\hline $\begin{array}{l}\text { Deposit Insurance * } \\
\text { Crop Price Index* State Bank }\end{array}$ & & $\begin{array}{c}0.027 \\
{[0.021]}\end{array}$ & & $\begin{array}{c}0.017 \\
{[0.024]}\end{array}$ & & $\begin{array}{l}-0.001 \\
{[0.007]}\end{array}$ \\
\hline $\begin{array}{l}\text { Crop Price Index * } \\
\text { Yr=1918 } \\
\text { County Controls? } \\
\text { Bank Fixed Effects? } \\
\text { Regulation Controls? } \\
\text { Year Fixed Effects? } \\
\text { Observations } \\
\text { R-squared } \\
\text { F-Test Statistic }\end{array}$ & $\begin{array}{c}0.127 * * * \\
{[0.033]} \\
\text { Yes } \\
\text { Yes } \\
\text { Yes } \\
\text { Yes } \\
65281 \\
0.755 \\
503.49 * * *\end{array}$ & $\begin{array}{c}0.103 * * * \\
{[0.033]} \\
\text { Yes } \\
\text { Yes } \\
\text { Yes } \\
\text { Yes } \\
65281 \\
0.764 \\
24.36^{* * *}\end{array}$ & $\begin{array}{c}-0.164 * * * \\
{[0.043]} \\
\text { Yes } \\
\text { Yes } \\
\text { Yes } \\
\text { Yes } \\
65281 \\
0.691 \\
283.31 * * *\end{array}$ & $\begin{array}{c}-0.173^{* * *} \\
{[0.039]} \\
\text { Yes } \\
\text { Yes } \\
\text { Yes } \\
\text { Yes } \\
65281 \\
0.703 \\
19.46^{* * *}\end{array}$ & $\begin{array}{c}-0.170^{* * *} \\
{[0.016]} \\
\text { Yes } \\
\text { Yes } \\
\text { Yes } \\
\text { Yes } \\
65281 \\
0.134 \\
17.28^{* * *}\end{array}$ & $\begin{array}{c}-0.164 * * * \\
{[0.016]} \\
\text { Yes } \\
\text { Yes } \\
\text { Yes } \\
\text { Yes } \\
65281 \\
0.141 \\
10.41 * * *\end{array}$ \\
\hline Crop Price Index & $\begin{array}{c}\text { (Capital+S } \\
-0.010^{* * *} \\
{[0.003]}\end{array}$ & $\begin{array}{c}\text { us)/ Assets } \\
0.009 \\
{[0.009]}\end{array}$ & $\begin{array}{c}\text { (Cash } \\
\text { Ban } \\
0.006 \\
{[0.005]}\end{array}$ & $\begin{array}{l}\text { from } \\
\text { ssets } \\
-0.095^{* * *} \\
{[0.013]}\end{array}$ & $\begin{array}{c}\text { Bonds and } \\
-0.027^{* * *} \\
{[0.005]}\end{array}$ & $\begin{array}{c}\text { cks/Assets } \\
-0.006 \\
{[0.013]}\end{array}$ \\
\hline $\begin{array}{l}\text { Crop Price Index * } \\
\text { State Bank }\end{array}$ & $\begin{array}{c}-0.013 * * * \\
{[0.001]}\end{array}$ & $\begin{array}{c}-0.032 * * * \\
{[0.009]}\end{array}$ & $\begin{array}{c}0.002 \\
{[0.002]}\end{array}$ & $\begin{array}{c}0.120^{* * *} \\
{[0.013]}\end{array}$ & $\begin{array}{c}0.003 \\
{[0.002]}\end{array}$ & $\begin{array}{c}0.002 \\
{[0.013]}\end{array}$ \\
\hline Young Bank & & $\begin{array}{l}0.000^{*} \\
{[0.000]}\end{array}$ & & $\begin{array}{c}0.000 * * * \\
{[0.000]}\end{array}$ & & $\begin{array}{l}-0.000 \\
{[0.000]}\end{array}$ \\
\hline Young Bank * State Bank & & $\begin{array}{c}-0.000^{* * *} \\
{[0.000]}\end{array}$ & & $\begin{array}{l}-0.000 \\
{[0.000]}\end{array}$ & & $\begin{array}{l}0.000^{* *} \\
{[0.000]}\end{array}$ \\
\hline $\begin{array}{l}\text { Young Bank * Crop } \\
\text { Price Index }\end{array}$ & & $\begin{array}{c}0.026^{* * *} \\
{[0.004]}\end{array}$ & & $\begin{array}{c}0.020 * * * \\
{[0.006]}\end{array}$ & & $\begin{array}{c}-0.013 * * \\
{[0.005]}\end{array}$ \\
\hline $\begin{array}{l}\text { Young Bank * Crop } \\
\text { Price Index * State Bank }\end{array}$ & & $\begin{array}{c}-0.028^{* * *} \\
{[0.004]}\end{array}$ & & $\begin{array}{c}-0.016^{* * *} \\
{[0.006]}\end{array}$ & & $\begin{array}{l}0.013^{* *} \\
{[0.005]}\end{array}$ \\
\hline $\begin{array}{l}\text { Fed Member * Crop } \\
\text { Price Index }\end{array}$ & & $\begin{array}{l}-0.018^{*} \\
{[0.009]}\end{array}$ & & $\begin{array}{c}0.087 * * * \\
{[0.013]}\end{array}$ & & $\begin{array}{c}-0.026 * * \\
{[0.012]}\end{array}$ \\
\hline Fed Member * Crop & & $0.025 * *$ & & $-0.106^{* * *}$ & & 0.017 \\
\hline
\end{tabular}


Price Index * State Bank

Extended Liability *

Crop Price Index

Extended Liability *

Crop Price Index * State Bank

Min Cap $>\$ 10,001 *$

Crop Price Index

Min Cap $>\$ 10,001 *$

Crop Price Index * State Bank

Deposit Insurance *

Crop Price Index

Deposit Insurance *

Crop Price Index* State Bank

Crop Price Index *

$\mathrm{Yr}=1918$

County Controls?

Bank Fixed Effects?

Regulation Controls?

Year Fixed Effects?

Observations

R-squared

F-Test Statistic
[0.010]

$-0.007 * *$

[0.003]

$0.015 * * *$

[0.003]

$0.005 *$

[0.002]

$-0.006 * *$

[0.003]

$-0.011 * * *$

[0.003]

$-0.018^{* * *}$

[0.003]

$-0.056 * * *$
$[0.006]$
Yes
Yes
Yes
Yes
65281
0.410

$136.76^{* * *}$

$-0.044 * * *$

[0.006]

Yes

Yes

Yes

Yes

65281

0.418

$11.02 * * *$
[0.014]

0.002

[0.005]

$-0.022 * * *$

[0.005]

0.011 **

[0.005]

$-0.006$

[0.005]

$0.017^{* * *}$

[0.005]

$-0.007$

[0.006]

$0.080^{* * *}$
$[0.011]$
Yes
Yes
Yes
Yes
65281
0.180
0.75

0.067 ***

[0.011]

Yes

Yes

Yes

Yes

65281

0.185

$15.17^{* * *}$
[0.014]

$0.018^{* * *}$

[0.006]

$-0.027 * * *$

[0.006]

0.003

[0.005]

$-0.042 * * *$

[0.006]

$-0.028 * * *$

[0.005]

$0.021 * * *$

[0.006]

0.073 ***

$0.082 * * *$
[0.014]

[0.012]

Yes

Yes

Yes

Yes

65281

0.199

$18.27 * * *$

Notes: The table presents the results of an OLS regression. The dependent variable is provided in the column heading. Each observation is a bank and each bank is observed every two years. The sample contains both state-chartered financial institutions (i.e., commercial banks, trust companies, and savings banks) and OCC-chartered financial institutions (i.e., national banks). "State Bank" is an indicator variable that denotes whether the bank was state-chartered. Only counties located in the Midwest, Great Plains, or South with consistent bank-level data published are included. The sample also excludes locations with a city over 25,000 persons, fewer than 250 farms, or fewer than 15,000 improved farm acres. County-level controls include the logarithms of county population and manufacturing output per person, the fraction of county population living in a city or town of 2,500 or more persons, the fractions of county population that are nonwhite, illiterate, or 15 years of age or younger, the number of national banks in the county, and the number of state banks in the county. Regulation controls include the presence of Extended liability, deposit insurance, minimum capital above \$10,001, and Fed membership for state banks. The F-Test Statistic jointly measures whether the differential effect of state bank interactions are significantly different from zero. Standard errors clustered by county are presented in parentheses below the coefficients. * denotes significance at $10 \% ; * *$ at 
Table A.12: Effect of Crop Price Shock on State Bank Closures Relative to National Bank Closures (1920-1924) Probability of Closing

State Bank

$\Delta$ Land Value Per Acre 1910-20

$\Delta$ Land Value Per Acre $1910-20 *$ State Bank

$\triangle$ Mortgage Debt

1910-20

$\triangle$ Mortgage Debt 1910-20 * State Bank

$\Delta$ Improved Acres

1910-20

$\triangle$ Improved Acres

1910-20 * State Bank

Ln(Mortgage Debt Per Acre)

Ln(Mortgage Debt Per

Acre) * State Bank

$\Delta$ Loans 1914-20

$\Delta$ Loans $1914-20 *$ State Bank

Fed Member * $\Delta$ Land Value

Per Acre 1910-20

Extended Liability * $\Delta$ Land

Value Per Acre 1910-20

Extended Liability * $\Delta$ Land

Value Per Acre 1910-20* State Bank

Min Cap. $>\$ 10,000 * \Delta$ Land

Value Per Acre 1910-20

Min Cap. $>\$ 10,000 * \Delta$ Land

Value Per Acre 1910-20 * State Bank

Deposit Insurance * $\Delta$ Land Value

Per Acre 1910-20

Deposit Insurance * $\Delta$ Land Value

Per Acre 1910-20 * State Bank

Ln(Assets)

Ln(Assets) * State Bank

Loans/Assets

Loans/Assets * State Bank

(Capital+Surplus)/Assets

(Capital+Surplus)/Assets * State Bank

Cash/Assets

Cash/Assets * State Bank
All Banks

(1)

$0.205^{* * *}$

[0.067]

0.046

[0.079]

$-0.028$

[0.068]

$-0.042 * *$

[0.018]

$0.036 * *$

[0.018]

$0.047 * * *$

[0.017]

$-0.049 * *$

[0.020]

0.021

[0.016]

$-0.025 *$

[0.014]

(2)
All Banks Est. Before 1914

(2)

$0.229 * * *$

[0.081]

0.015

[0.078]

0.000

[0.069]

$-0.032$

[0.020]

0.024

[0.020]

0.041 *

[0.025]

$-0.046^{*}$

[0.027]

0.030 *

[0.018]

$-0.034 * *$

[0.015]

0.032

[0.021]

$-0.015$

[0.022]

0.017

[0.059]

0.023

[0.056]

0.003

[0.031]

$-0.008$

[0.040]

0.023

[0.024]

0.078 *

[0.045]

0.005

[0.028]

$-0.010$

[0.012]

$-0.033 * * *$

[0.012]

$-0.027$

[0.090]

0.147

[0.097]

0.002

[0.170]

$-0.147$

[0.174]

$-0.387^{* *}$

[0.156]

0.071 
Age Controls?

County Controls?

State Fixed Effects?

Regulation Fixed Effects?

Fed District Fixed Effects?

Observations

Pseduo-R-squared

F-Test Statistic
Yes

Yes

Yes

Yes

Yes

12634

$22.9 * *$
Yes

Yes

Yes

Yes

Yes

10079

0.124

$22.68^{* *}$

Notes: The table presents the marginal effects from a Probit regression. The dependent variable is an indicator variable for whether the bank closed before 1924. Each observation is a bank in 1920. The column headings denote which banks are included in the regressions.

Only counties located in the Midwest, Great Plains, or South with consistent bank-level data published are included. The sample also excludes locations with a city over 25,000 persons, fewer than 250 farms, or fewer than 15,000 improved farm acres. County-level controls include the logarithms of county population and manufacturing output per person, the fraction of county population living in a city or town of 2,500 or more persons, the fractions of county population that are non-white, illiterate, or 15 years of age or younger, the number of national banks in the county, the number of state banks in the county, the logarithm of the county's size in square miles, average rainfall in the county, the standard deviation of rainfall in the county, distances to Mississippi River, Atlantic Ocean, Great Lakes, and Pacific Ocean, and a set of Fed district fixed effects. Because of state fixed effects, tegulation controls include deposit insurance and Fed membership for state banks. The F-Test Statistic jointly measures whether the differential effect of state bank interactions are significantly different from zero. Robust standard errors clustered by county are presented in parentheses below the coefficients. * denotes significance at $10 \%$; ** at $5 \%$ level and $* * *$ at $1 \%$ levels. 
Table A.13: Determinants of Bank Closure (1920-1924)

\begin{tabular}{|c|c|c|c|c|}
\hline & & Probabi & Closing & \\
\hline & All State Banks & $\begin{array}{c}\text { State Banks Est. } \\
\text { Before } 1914\end{array}$ & All Nat. Banks & $\begin{array}{c}\text { Nat. Banks Est. } \\
\text { Before } 1914\end{array}$ \\
\hline $\begin{array}{l}\Delta \text { Land Value Per Acre } \\
1910-20\end{array}$ & $\begin{array}{c}(1) \\
0.050^{*} \\
{[0.027]}\end{array}$ & $\begin{array}{c}(4) \\
0.034 \\
{[0.030]}\end{array}$ & $\begin{array}{c}(6) \\
0.081 * * * \\
{[0.031]}\end{array}$ & $\begin{array}{c}(8) \\
0.048 \\
{[0.033]}\end{array}$ \\
\hline $\begin{array}{l}\Delta \text { Land Value Per Acre } \\
1920-25\end{array}$ & $\begin{array}{l}-0.001 \\
{[0.037]}\end{array}$ & $\begin{array}{c}0.021 \\
{[0.038]}\end{array}$ & $\begin{array}{l}-0.110^{*} \\
{[0.058]}\end{array}$ & $\begin{array}{l}-0.091 \\
{[0.057]}\end{array}$ \\
\hline $\begin{array}{l}\Delta \text { Land Value } 1910-20 * \\
\Delta \text { Land Value } 1920-25\end{array}$ & $\begin{array}{c}-0.087 * * \\
{[0.040]}\end{array}$ & $\begin{array}{c}-0.096^{* *} \\
{[0.043]}\end{array}$ & $\begin{array}{c}0.080 \\
{[0.063]}\end{array}$ & $\begin{array}{c}0.079 \\
{[0.063]}\end{array}$ \\
\hline $\begin{array}{l}\Delta \text { Mortgage Debt } \\
1910-20\end{array}$ & $\begin{array}{l}-0.006 \\
{[0.011]}\end{array}$ & $\begin{array}{c}-0.008 \\
{[0.012]}\end{array}$ & $\begin{array}{l}-0.005 \\
{[0.014]}\end{array}$ & $\begin{array}{c}0.004 \\
{[0.013]}\end{array}$ \\
\hline $\begin{array}{l}\Delta \text { Improved Acres } \\
1910-20\end{array}$ & $\begin{array}{c}0.003 \\
{[0.012]}\end{array}$ & $\begin{array}{c}-0.002 \\
{[0.009]}\end{array}$ & $\begin{array}{c}0.054 * * * \\
{[0.014]}\end{array}$ & $\begin{array}{c}0.048^{* * *} \\
{[0.015]}\end{array}$ \\
\hline $\begin{array}{l}\text { Ln(Mortgage Debt Per } \\
\text { Acre) }\end{array}$ & $\begin{array}{c}-0.012 \\
{[0.013]}\end{array}$ & $\begin{array}{c}-0.007 \\
{[0.014]}\end{array}$ & $\begin{array}{c}0.004 \\
{[0.017]}\end{array}$ & $\begin{array}{c}-0.006 \\
{[0.015]}\end{array}$ \\
\hline$\Delta$ Loans $1914-20$ & & $\begin{array}{l}0.018 * * \\
{[0.008]}\end{array}$ & & $\begin{array}{c}0.016 \\
{[0.014]}\end{array}$ \\
\hline Ln(Assets) & $\begin{array}{c}-0.049 * * * \\
{[0.007]}\end{array}$ & $\begin{array}{c}-0.045^{* * *} \\
{[0.007]}\end{array}$ & $\begin{array}{c}-0.028^{* * *} \\
{[0.011]}\end{array}$ & $\begin{array}{l}-0.015 \\
{[0.010]}\end{array}$ \\
\hline Loans/Assets & $\begin{array}{c}0.120^{* * * *} \\
{[0.041]}\end{array}$ & $\begin{array}{c}0.135^{* * * *} \\
{[0.046]}\end{array}$ & $\begin{array}{c}0.062 \\
{[0.061]}\end{array}$ & $\begin{array}{c}-0.012 \\
{[0.056]}\end{array}$ \\
\hline (Capital+Surplus)/Assets & $\begin{array}{l}-0.082 \\
{[0.058]}\end{array}$ & $\begin{array}{l}-0.139^{*} \\
{[0.072]}\end{array}$ & $\begin{array}{l}-0.090 \\
{[0.100]}\end{array}$ & $\begin{array}{l}-0.207 \\
{[0.131]}\end{array}$ \\
\hline Cash/Assets & $\begin{array}{c}-0.291 * * * \\
{[0.062]}\end{array}$ & $\begin{array}{c}-0.350 * * * \\
{[0.073]}\end{array}$ & $\begin{array}{l}-0.190^{*} \\
{[0.108]}\end{array}$ & $\begin{array}{c}-0.255^{* *} \\
{[0.100]}\end{array}$ \\
\hline Entered in 1918 & $\begin{array}{c}-0.034 * * * \\
{[0.012]}\end{array}$ & & $\begin{array}{c}-0.023 \\
{[0.019]}\end{array}$ & \\
\hline Entered in 1916 & $\begin{array}{c}-0.067 * * * \\
{[0.011]}\end{array}$ & & $\begin{array}{c}-0.034^{* *} \\
{[0.015]}\end{array}$ & \\
\hline Entered in 1914 & $\begin{array}{c}-0.051 * * * \\
{[0.011]}\end{array}$ & & $\begin{array}{l}-0.025 \\
{[0.018]}\end{array}$ & \\
\hline Entered in 1912 & $\begin{array}{c}-0.049 * * * \\
{[0.011]}\end{array}$ & $\begin{array}{c}0.012 \\
{[0.016]}\end{array}$ & $\begin{array}{c}-0.036 * * * \\
{[0.014]}\end{array}$ & $\begin{array}{c}-0.009 \\
{[0.019]}\end{array}$ \\
\hline Entered in 1910 & $\begin{array}{c}-0.064 * * * \\
{[0.010]}\end{array}$ & $\begin{array}{c}-0.007 \\
{[0.014]}\end{array}$ & $\begin{array}{c}-0.044 * * * \\
{[0.013]}\end{array}$ & $\begin{array}{c}-0.019 \\
{[0.017]}\end{array}$ \\
\hline Entered in 1908 or Earlier & $\begin{array}{c}-0.083 * * * \\
{[0.014]}\end{array}$ & $\begin{array}{c}-0.008 \\
{[0.013]}\end{array}$ & $\begin{array}{c}-0.078 * * * \\
{[0.025]}\end{array}$ & $\begin{array}{c}-0.033 \\
{[0.025]}\end{array}$ \\
\hline County Controls? & Yes & Yes & Yes & Yes \\
\hline State Fixed Effects? & Yes & Yes & Yes & Yes \\
\hline Fed District Fixed Effects? & Yes & Yes & Yes & Yes \\
\hline Observations & 10052 & 7857 & 2533 & 2176 \\
\hline Pseduo-R-squared & 0.130 & 0.125 & 0.145 & 0.137 \\
\hline
\end{tabular}

Notes: The table presents the marginal effects from a Probit regression. The dependent variable is an indicator variable for whether the bank closed before 1924. Each observation is a bank in 1920. The column headings denote which banks are included in the regressions. Only counties located in the Midwest, Great Plains, or South with consistent bank-level data published are included. The sample also excludes locations with a city over 25,000 persons, fewer than 250 farms, or fewer than 15,000 improved farm acres. County-level controls include the logarithms of county population and manufacturing output per person, the fraction of county population living in a city or town of 2,500 or more persons, the fractions of county population that are non-white, illiterate, or 15 years of age or younger, the number of national banks in the county, the number of state banks in the county, the logarithm of the county's size in square miles, average rainfall in the county, the standard deviation of rainfall in the county, distances to Mississippi River, Atlantic Ocean, Great Lakes, and Pacific Ocean, and a set of Fed district fixed effects. Robust standard errors clustered by county are presented in parentheses below the coefficients. $*$ denotes significance at $10 \%$;* at $5 \%$ level and $* * *$ at $1 \%$ levels. 
Table A.14: Determinants of the Agricultural Boom (1910-20)

\begin{tabular}{lcccc}
\hline & \multicolumn{3}{c}{ Change in Ln(Farmland Value Per Acre) } \\
\cline { 2 - 4 }$\Delta$ Crop Price Index 1910-19 & $(1)$ & $(2)$ & $(3)$ & $0.160^{* *}$ \\
& $0.170^{* *}$ & 0.067 & {$[0.069]$} & {$[0.099]$} \\
Number of State Banks & {$[0.071]$} & {$[0.102]$} & $0.004^{*}$ & $-0.066^{* * *}$ \\
in 1910 & 0.003 & $-0.068^{* * *}$ & {$[0.002]$} & {$[0.020]$} \\
Number of National Banks & {$[0.002]$} & {$[0.020]$} & $0.013^{* * *}$ & $0.139^{* * *}$ \\
in 1910 & $0.010^{* *}$ & $0.141^{* * *}$ & {$[0.004]$} & {$[0.043]$} \\
State Banks in 1910* & {$[0.004]$} & {$[0.045]$} & & $0.046^{* * *}$ \\
$\Delta$ Crop Price Index 1910-19 & & $0.047^{* * *}$ & & {$[0.013]$} \\
National Banks in 1910* & & $0.013]$ & & $-0.081^{* * *}$ \\
$\Delta$ Crop Price Index 1910-19 & & $-0.084^{* * *}$ & & {$[0.028]$} \\
$\Delta$ State Bank Loans & {$[0.029]$} & & $0.011^{* *}$ \\
1910-20 & & & $0.010^{* *}$ & {$[0.005]$} \\
$\Delta$ National Bank Loans & & & $0.005]$ & $0.007^{* * *}$ \\
1910-20 & & & $0.007^{* * *}$ & {$[0.002]$} \\
County-Level Controls? & & & {$[0.002]$} & Yes \\
State Fixed Effects? & Yes & Yes & Yes & Yes \\
Fed District Fixed Effects? & Yes & Yes & Yes & Yes \\
Observations & Yes & Yes & Yes & 1199 \\
R-squared & 1199 & 1199 & 1199 & 0.506 \\
\hline
\end{tabular}

Notes: The table presents the results of an OLS regression. The dependent variable is the percentage change in farm land value per acre 1910-20. Each observation is a county. Only counties located in the Midwest, Great Plains, or South with consistent bank-level data published are included. The sample also excludes locations with a city over 25,000, fewer than 250 farms, or fewer than 15,000 improved farming acres. County-level controls include the logarithms of county population and manufacturing output per person, the fraction of county population living in a city or town of 2,500 or more persons, the fractions of county population that are nonwhite, illiterate, or 15 years of age or younger, the number of national banks in the county, the number of state banks in the county, the logarithm of the county's size in square miles, average rainfall in the county, the standard deviation of rainfall in the county, distances to Mississippi River, Atlantic Ocean, Great Lakes, and Pacific Ocean, the percentage of unimproved land in the county, and a set of Fed district fixed effects. Robust standard errors are presented in parentheses below the coefficients. $*$ denotes significance at $10 \% ; * *$ at $5 \%$ level and *** at $1 \%$ levels. 
Table A.15: Determinants of the Agricultural Bust - Using Predicted Closure Probability Cutoffs (1920-25)

\begin{tabular}{lccc} 
& \multicolumn{3}{c}{ Change in Ln(Farm Land Value Per Acre) } \\
\cline { 2 - 4 }$\Delta$ Crop Price Index 1919-25 & $(1)$ & $(2)$ & $(3)$ \\
& $0.287^{* * *}$ & $0.282^{* * *}$ & $0.284^{* * *}$ \\
$\Delta$ Farm Land Value 1910-20 & {$[0.056]$} & {$[0.056]$} & {$[0.056]$} \\
& $-0.303^{* * *}$ & $-0.292^{* * *}$ & $-0.298^{* * *}$ \\
Number of State Banks & {$[0.042]$} & {$[0.044]$} & {$[0.044]$} \\
in 1920 & 0.002 & 0.002 & 0.001 \\
Number of National Banks & {$[0.003]$} & {$[0.002]$} & {$[0.002]$} \\
in 1920 & -0.002 & -0.001 & -0.001 \\
Predicted Number of State Bank Closures & {$[0.004]$} & {$[0.003]$} & {$[0.003]$} \\
1920-25 (With 5\% Cutoff) & -0.003 & & \\
Predicted Number of National Bank Closures & {$[0.002]$} & & \\
1920-25 (With 5\% Cutoff) & 0.002 & & \\
Predicted Number of State Bank Closures & {$[0.004]$} & & \\
1920-25 (With 10\% Cutoff) & & $-0.004 * *$ & \\
Predicted Number of National Bank Closures & & {$[0.002]$} & \\
1920-25 (With 10\% Cutoff) & & 0.002 & \\
Predicted Number of State Bank Closures & & {$[0.006]$} & \\
1920-25 (With 15\% Cutoff) & & & $-0.004^{*}$ \\
Predicted Number of National Bank Closures & & & {$[0.002]$} \\
1920-25 (With 15\% Cutoff) & & & 0.005 \\
County Controls? & Yes & Yes & Yes \\
State Fixed Effects? & Yes & Yes & Yes \\
Fed District Fixed Effects? & 1247 & Yes & Yes \\
Observations & 0.626 & 0.627 & 1247 \\
R-squared & & & 0.626 \\
\hline
\end{tabular}

Notes: The table presents the results of an OLS regression. The dependent variable is the percentage change in farmland value per acre 1920-25. Each observation is a county. Only counties located in the Midwest, Great Plains, or South with consistent bank-level data published are included. The sample also excludes locations with a city over 25,000, fewer than 250 farms, or fewer than 15,000 improved farming acres. The "Predicted Number" of closures is obtained by estimating each bank's probability of closure from columns (2) and (6) of Table 4 and counting the number of banks with a probability of closure higher than the specified cutoff value. County-level controls include the logarithms of county population and manufacturing output per person, the fraction of county population living in a city or town of 2,500 or more persons, the fractions of county population that are non-white, illiterate, or 15 years of age or younger, the number of national banks in the county, the number of state banks in the county, the logarithm of the county's size in square miles, average rainfall in the county, the standard deviation of rainfall in the county, distances to Mississippi River, Atlantic Ocean, Great Lakes, and Pacific Ocean, the percentage of unimproved land in the county, and a set of Fed district fixed effects. Robust standard errors are presented in parentheses below the coefficients. ${ }^{*}$ denotes significance at $10 \%$; ** at $5 \%$ level and $* * *$ at $1 \%$ levels. 